\title{
Schoolverlaters tussen onderwijs en arbeidsmarkt 1996.
}

\author{
Citation for published version (APA):
}

Researchcentrum voor Onderwijs en Arbeidsmarkt, ROA. (1997). Schoolverlaters tussen onderwijs en arbeidsmarkt 1996. Kerngegevens. Researchcentrum voor Onderwijs en Arbeidsmarkt, Faculteit der Economische Wetenschappen. ROA Reports No. 003B https://doi.org/10.26481/umarep.1997003B

\section{Document status and date:}

Published: 01/01/1997

DOI:

10.26481/umarep.1997003B

Document Version:

Publisher's PDF, also known as Version of record

\section{Please check the document version of this publication:}

- A submitted manuscript is the version of the article upon submission and before peer-review. There can be important differences between the submitted version and the official published version of record.

People interested in the research are advised to contact the author for the final version of the publication, or visit the DOI to the publisher's website.

- The final author version and the galley proof are versions of the publication after peer review.

- The final published version features the final layout of the paper including the volume, issue and page numbers.

Link to publication

\footnotetext{
General rights rights.

- You may freely distribute the URL identifying the publication in the public portal. please follow below link for the End User Agreement:

www.umlib.nl/taverne-license

Take down policy

If you believe that this document breaches copyright please contact us at:

repository@maastrichtuniversity.nl

providing details and we will investigate your claim.
}

Copyright and moral rights for the publications made accessible in the public portal are retained by the authors and/or other copyright owners and it is a condition of accessing publications that users recognise and abide by the legal requirements associated with these

- Users may download and print one copy of any publication from the public portal for the purpose of private study or research.

- You may not further distribute the material or use it for any profit-making activity or commercial gain

If the publication is distributed under the terms of Article $25 \mathrm{fa}$ of the Dutch Copyright Act, indicated by the "Taverne" license above, 


\section{Kerngegevens \\ Schoolverlaters tussen onderwijs en arbeidsmarkt 1996}

ROA-R-1997/3B

Researchcentrum voor Onderwijs en Arbeidsmarkt

Faculteit der Economische Wetenschappen en Bedrijfskunde

Universiteit Maastricht

Maastricht, juni 1997 
Niets uit deze uitgave mag worden verveelvoudigd en/of openbaar gemaakt door middel van druk, fotokopie, microfilm, of op welke wijze ook, zonder voorafgaande schriftelijke toestemming van de directeur van het Researchcentrum voor Onderwijs en Arbeidsmarkt. In geval van overname van het datamateriaal moet telkens duidelijk als bron worden vermeld: "Researchcentrum voor Onderwijs en Arbeidsmarkt" of "ROA". Van publicaties waarin gebruik wordt gemaakt van gegevens uit deze Kerngegevens ontvangen wij gaarne een exemplaar.

Hoewel de grootst mogelijke zorg is besteed aan de inhoud van dit rapport, kan het ROA in generlei opzicht verantwoordelijkheid op zich nemen voor eventuele onvolledigheden of onjuistheden.

ISBN 90-5321-205-1

SEC97.050 


\section{Inhoud}

Bladzijde

Voorwoord

\section{A. Tabellen per opleidingssector}

\section{Bestemming van schoolverlaters}

A1.1 De uitstroom van schoolverlaters verbijzonderd naar geslacht, etniciteit en gemiddelde leeftijd

A1.2 Vooropleiding van schoolverlaters

A1.3 Bestemming van schoolverlaters

2 Doorstroom naar vervolgonderwijs

A2.1 Doorstroom van schoolverlaters naar het voltijd vervolgonderwijs

A2.2 Belangrijkste opleidingen van schoolverlaters die een voltijd vervolgopleiding zijn gaan volgen

A2.3 Oordeel van schoolverlaters over de aansluiting van de afgesloten opleiding met een voltijd vervolgopleiding en het percentage schoolverlaters dat deze vervolgopleiding achteraf bezien opnieuw zou kiezen

A2.4 Doorstroom van schoolverlaters naar het duale onderwijs

A2.5 Oordeel van schoolverlaters over de aansluiting van de afgesloten opleiding met de duale vervolgopleiding en het percentage schoolverlaters dat deze duale vervolgopleiding achteraf bezien opnieuw zou kiezen

3 Intrede op de arbeidsmarkt

A3.1 Werkloosheid en gemiddelde intredewerkloosheid van schoolverlaters die zich aanbieden op de arbeidsmarkt

A3.2 Aard van het dienstverband van werkende schoolverlaters

A3.3 Percentage werkende schoolverlaters met een flexibele aanstelling 20

A3.4 Wijze van verkrijgen van een baan $\quad 21$

A3.5 Belangrijkste bedrijfsgroepen waarin schoolverlaters werkzaam zijn 22

A3.6 Belangrijkste beroepsgroepen waarin schoolverlaters werkzaam zijn 26

A3.7 Grootte van de organisatie waarin schoolverlaters werkzaam zijn 30

A3.8 Beloning van werkende schoolverlaters $\quad 31$

A3.9 Vereist opleidingsniveau voor de huidige functie volgens de schoolverlaters en de werkgever

A3.10 Vereist opleidingsrichting voor de huidige functie volgens de schoolverlaters en de werkgever

A3.11 Gewenste en feitelijke wekelijkse arbeidsduur van werkende schoolverlaters $\quad 34$

A3.12 Oordeel van de werkende schoolverlaters over de aansluiting tussen de afgesloten opleiding en de huidige functie

A3.13 Percentage werkende schoolverlaters dat op zoek is naar een andere baan 
A3.14 Deelname aan een cursus of bedrijfsopleiding door werkende schoolverlaters

A3.15 Belangrijkste cursussen of bedrijfsopleidingen waaraan werkende schoolverlaters deelnemen

\section{B. Tabellen per opleidingsrichting}

1 Bestemming van schoolverlaters

B1.1 De uitstroom van schoolverlaters verbijzonderd naar geslacht, etniciteit en gemiddelde leeftijd

B1.2 Vooropleiding van schoolverlaters 46

$\begin{array}{lll}\text { B1.3 } & \text { Bestemming van schoolverlaters } & 47\end{array}$

\section{Doorstroom naar vervolgonderwijs}

B2.1 Doorstroom van schoolverlaters naar het voltijd vervolgonderwijs

B2.2 Belangrijkste opleidingen van schoolverlaters die een voltijd vervolgopleiding zijn gaan volgen

B2.3 Oordeel van schoolverlaters over de aansluiting van de afgesloten opleiding met de voltijd vervolgopleiding en het percentage schoolverlaters dat deze vervolgopleiding achteraf bezien opnieuw zou kiezen

B2.4 Doorstroom van schoolverlaters naar het duale vervolgvonderwijs

B2.5 Oordeel van schoolverlaters over de aansluiting van de afgesloten opleiding met de duale vervolgopleiding en het percentage schoolverlaters dat deze duale vervolgopleiding achteraf bezien opnieuw zou kiezen

3 Intrede op de arbeidsmarkt

B3.1 Werkloosheid en gemiddelde intredewerkloosheid van schoolverlaters die zich aanbieden op de arbeidsmarkt

B3.2 Aard van het dienstverband van werkende schoolverlaters

B3.3 Percentage werkende schoolverlaters met een flexibele aanstelling

B3.4 Wijze van verkrijgen van een baan

B3.5 Belangrijkste bedrijfsgroepen waarin schoolverlaters werkzaam zijn

B3.6 Belangrijkste beroepsgroepen waarin schoolverlaters werkzaam zijn

B3.7 Grootte van de organisatie waarin schoolverlaters werkzaam zijn

B3.8 Beloning van werkende schoolverlaters

B3.9 Vereist opleidingsniveau voor de huidige functie volgens de schoolverlaters en de werkgever

B3.10 Vereiste opleidingsrichting voor de huidige functie volgens de schoolverlaters en de werkgever

B3.11 Gewenste en feitelijke wekelijkse arbeidsduur van werkende schoolverlaters

B3.12 Oordeel van de werkende schoolverlaters over de aansluiting tussen de afgesloten opleiding en de huidige functie

B3.13 Percentage werkende schoolverlaters dat op zoek is naar een andere baan

B3.15 Belangrijkste cursussen of bedrijfsopleidingen waaraan werkende schoolverlaters deelnemen 


\section{Respons}

C.1 Ongewogen aantal respondenten verbijzonderd naar bestemming per opleidingssector

C.2 Naar landelijke populatie gewogen aantal schoolverlaters verbijzonderd naar bestemming per opleidingssector

C.3 Responspercentage per opleidingssector

C.4 Ongewogen aantal respondenten verbijzonderd naar bestemming per opleidingsrichting

C.5 Naar landelijke populatie gewogen aantal schoolverlaters verbijzonderd naar bestemming per opleidingsrichting

C.6 Responspercentage per opleidingsrichting

\section{Opleidingsindeling}

Overzicht van opleidingen per opleidingssector 



\section{Voorwoord}

Deze rapportage Kerngegevens als bijlage bij het rapport Schoolverlaters tussen onderwijs en arbeidsmarkt 1996 geeft een statistisch overzicht van de belangrijkste inhoud van het Schoolverlatersinformatiesysteem. Dit informatiesysteem is door het ROA ontwikkeld op basis van enkele grootschalige enquête-onderzoeken onder schoolverlaters en pas afgestudeerden. Enerzijds betreft dit de enquête Registratie van Uitstroom en Bestemming van Schoolverlaters (RUBS), die is gericht op de schoolverlaters van het Algemeen Voortgezet Onderwijs (AVO), het Voorbereidend Beroepsonderwijs (VBO) en de korte, tussen en lange variant van het Middelbaar Beroepsonderwijs (MBO). Anderzijds is dit de HBO-Monitor en de Kunsten-Monitor, gericht op respectievelijk de afgestudeerden van het Hoger Beroepsonderwijs (HBO) en het Kunst-vakonderwijs.

De genoemde schoolverlatersonderzoeken hebben een tweevoudige doelstelling. In de eerste plaats is het een kwaliteitszorginstrument voor individuele (hoge)scholen of specifieke opleidingsrichtingen daarbinnen. Scholen ontvangen daartoe een uniek vertrouwelijk instellingsrapport met de resultaten van hun 'eigen' schoolverlaters of afgestudeerden ${ }^{1}$. Door het grootschalige karakter van de onderzoeken en de goede onderlinge afstemming wordt echter ook een statistisch betrouwbare landelijk representatieve dataset opgebouwd. Deze landelijke gegevens vormen niet alleen het ijkpunt binnen de schoolspecifieke rapportages, maar zijn tevens een belangrijke informatiebron voor nadere analyses op het gebied van de overgang van school naar werk.

Kerngegevens is in vier delen onderverdeld. Deel $A$ bevat gegevens per opleidingssector (bijvoorbeeld MBO techniek, HBO gedrag en maatschappij). Deel $B$ geeft vervolgens voor het VBO en het (kort) MBO een gedetailleerder overzicht (bijvoorbeeld MBO bouwtechniek) ${ }^{2}$. Daarbij worden alleen voor die opleidingen resultaten gepresenteerd, waarvoor dit in het algemeen voldoende betrouwbaar wordt geacht. Eenvoudigheidshalve is daartoe voor alle tabellen als strikte grens gehanteerd dat er ten minste 15 werkenden aan de enquête hebben deelgenomen. Dit betekent overigens dat in sommige tabellen de gepresenteerde percentages zijn gebaseerd op een geringer aantal waarnemingen. Hiermee dient bij de interpretatie van de gegevens rekening te worden gehouden. Voor alle tabellen geldt dat alleen de resultaten van gediplomeerde schoolverlaters van de voltijd opleidingen worden gepresenteerd.

Beide delen A en B kunnen vervolgens weer in drie hoofdcategorieën worden opgedeeld. Deel 1 gaat in op de bestemming van schoolverlaters: hebben zij werk of gaan ze verder leren. In deel 2 wordt vervolgens ingezoomd op de verder lerenden: welke opleidingen volgen zij en hoe beoordelen zij de aansluiting tussen de afgesloten opleiding en deze vervolgopleiding. Het merendeel van de tabellen - deel 3 - betreft echter de intrede op de arbeidsmarkt. Daarbij gaat het om gegevens over werkloosheid, benutting en beloning van schoolverlaters, aard van de contracten, belangrijkste beroepen en branches enz.

Voorts bevat deel C enkele tabellen die meer inzicht geven in de kwaliteit van de gegevens. Dit

1. De RUBS-enquête en de desbetreffende instellingsrapportages worden bij de deelnemende scholen aangeboden door het Landelijk Dienstverlenend Centrum voor Studie- en Beroepskeuzevoorlichting (LDC). De aanbieding van de HBO-Monitor aan de hogescholen verloopt via de HBO-Raad.

2. Voor een gedetailleerder overzicht van de resultaten voor het HBO wordt verwezen naar het gelijktijdig verschenen rapport en statistisch supplement van de HBO-Monitor. 
betreft in de eerste plaats het aantal respondenten, verbijzonderd naar bestemmingscategorie. Hiermee kan een (eerste) indicatie worden verkregen van de betrouwbaarheid van de gegevens. Daarnaast wordt een overzicht gegeven van de tot landelijke cijfers opgehoogde aantallen schoolverlaters. Ook de responspercentages worden in dit deel gepresenteerd. Wederom zijn de resultaten zowel per opleidingssector als op het gedetailleerdere niveau van opleidingsrichtingen weergegeven. Tot slot is in deel $D$ een overzicht opgenomen van de opleidingen die tot de verschillende opleidingssectoren, zoals gehanteerd in deze bijlage, worden gerekend.

Deze bijlage met Kerngegevens bevat alleen gegevens over de eind 1996 gehouden enquêtes, gericht op schoolverlaters van het school- of studiejaar 1994/1995. Een vergelijking met 1995 wordt niet gemaakt. De belangrijkste reden hiervoor is dat het meetmoment van de RUBS-enquête tussen 1995 en 1996 is verschoven van het voorjaar naar het najaar. Dit betekent dat de respondenten gemiddeld een half jaar langer van school zijn, hetgeen zowel voor de verder lerenden als voor de intreders op de arbeidsmarkt tot andere resultaten zal leiden (hogere uitval in vervolgonderwijs, hogere beloningen e.d.).

Zoals gezegd vormen de enquêtes RUBS en HBO-Monitor de input van het Schoolverlatersinformatiesysteem. Deze enquêtes worden gefinancierd door de deelnemende scholen en hogescholen, alsmede het LDC en de HBO-Raad. De landelijke analyses zijn financieel mogelijk gemaakt door bijdragen van de Ministeries van Onderwijs, Cultuur en Wetenschappen, Sociale Zaken en Werkgelegenheid en Landbouw, Natuurbeheer en Visserij en het LDC. Bij de uitvoering van het onderzoek werkt het ROA samen DESAN Marktonderzoek b.v. te Amsterdam. Dit bureau verzorgt de dataverzameling en -verwerking, alsmede de individuele vertrouwelijke rapportages voor de deelnemende onderwijsinstellingen. Kemgegevens is binnen het ROA samengesteld door A.M. Kleijnen onder begeleiding van drs. E.J.T.A. Willems. 
A. Tabellen per opleidingssector 
Tabel A1.1

De uitstroom van schoolverlaters verbijzonderd naar geslacht, etniciteit en gemiddelde leeftijd

\begin{tabular}{|c|c|c|c|}
\hline Opleidingssector & $\begin{array}{c}\text { vrouw } \\
\%\end{array}$ & $\begin{array}{c}\text { alloch- } \\
\text { toon } \\
\%\end{array}$ & $\begin{array}{l}\text { gem. } \\
\text { leeftijd }\end{array}$ \\
\hline
\end{tabular}

AVO

MAVO

HAVO

WWO

$\begin{array}{lll}54 & 2 & 16,4 \\ 56 & 3 & 18,1 \\ 50 & 3 & 18,6 \\ 53 & 2 & 17,5\end{array}$

VBO

landbouw

techniek

economie

gezondheidszorg

Totaal

$\begin{array}{rrr}47 & 1 & 16,6 \\ 7 & 13 & 17,1 \\ 58 & 21 & 17,1 \\ 93 & 13 & 16,7 \\ 40 & 14 & 17,0\end{array}$

MBO-kort

oriënteren en schakelen

landbouw

techniek

economie

gezondheidszorg

Totaal

45

53

90

53

6,4

18,1
18,6

17,5

\section{MBO-tussen en -lang}

landbouw

techniek

economie

gezondheidszorg

gedrag en maatschappij

Totaal

$\begin{array}{lll}32 & 1 & 20,5 \\ 12 & 2 & 21,0 \\ 52 & 3 & 20,5 \\ 94 & 3 & 20,4 \\ 90 & 3 & 20,6 \\ 46 & 3 & 20,7\end{array}$

HBO

landbouw

onderwijs

techniek

economie

gezondheidszorg

gedrag en maatschappij

kunst en cultuur

Totaal

$\begin{array}{rr}11 & 18,3 \\ 1 & 19,9 \\ 8 & 19,9 \\ 8 & 19,3 \\ 5 & 19,3 \\ 9 & 19,1\end{array}$

Totaal

33

82

15

47

83

81

49

49

Toelichting

- ledereen die zichzelf niet tot de Nederlandse bevolkingsgroep rekent wordt als allochtoon aangemerkt.

- Het betreft de leeftijd per onderzoeksdatum. 
Tabel A1.2

Vooropleiding van schoolverlaters

\begin{tabular}{cccccccc}
\hline Opleidingssector & MAVO & HAVO & WWO & VBO & $\begin{array}{c}\text { MBO- } \\
\text { kort }\end{array}$ & MBO & overig \\
& $\%$ & $\%$ & $\%$ & $\%$ & $\%$ & $\%$ & $\%$ \\
\hline
\end{tabular}

\section{MBO-kort}

\begin{tabular}{|c|c|c|c|c|c|c|c|}
\hline $\begin{array}{l}\text { oriënteren en schakelen } \\
\text { landbouw } \\
\text { techniek } \\
\text { economie } \\
\text { gezondheidszorg } \\
\text { Totaal }\end{array}$ & $\begin{array}{r}22 \\
31 \\
21 \\
33 \\
9 \\
25\end{array}$ & $\begin{array}{l}0 \\
1 \\
2 \\
3 \\
0 \\
2\end{array}$ & $\begin{array}{l}2 \\
0 \\
1 \\
0 \\
0 \\
1\end{array}$ & $\begin{array}{l}74 \\
53 \\
65 \\
58 \\
85 \\
67\end{array}$ & $\begin{array}{l}1 \\
7 \\
6 \\
4 \\
3 \\
4\end{array}$ & $\begin{array}{l}0 \\
8 \\
3 \\
1 \\
2 \\
1\end{array}$ & $\begin{array}{l}1 \\
0 \\
1 \\
0 \\
1 \\
1\end{array}$ \\
\hline \multicolumn{8}{|l|}{ MBO-tussen en -lang } \\
\hline $\begin{array}{l}\text { landbouw } \\
\text { techniek } \\
\text { economie } \\
\text { gezondheidszorg } \\
\text { gedrag en maatschappij } \\
\text { Totaal }\end{array}$ & $\begin{array}{l}37 \\
55 \\
55 \\
58 \\
66 \\
55\end{array}$ & $\begin{array}{r}8 \\
13 \\
28 \\
7 \\
4 \\
17\end{array}$ & $\begin{array}{l}1 \\
1 \\
2 \\
0 \\
1 \\
1\end{array}$ & $\begin{array}{l}50 \\
25 \\
11 \\
30 \\
25 \\
22\end{array}$ & $\begin{array}{l}1 \\
2 \\
2 \\
2 \\
2 \\
2\end{array}$ & $\begin{array}{l}3 \\
5 \\
2 \\
2 \\
2 \\
3\end{array}$ & $\begin{array}{l}0 \\
0 \\
0 \\
1 \\
1 \\
0\end{array}$ \\
\hline \multicolumn{8}{|l|}{ HBO } \\
\hline $\begin{array}{l}\text { landbouw } \\
\text { onderwijs } \\
\text { techniek } \\
\text { economie } \\
\text { gezondheidszorg } \\
\text { gedrag en maatschappij } \\
\text { kunst en cultuur } \\
\text { Totaal }\end{array}$ & $\begin{array}{l}1 \\
2 \\
1 \\
0 \\
1 \\
1 \\
5 \\
1\end{array}$ & $\begin{array}{l}36 \\
64 \\
28 \\
25 \\
49 \\
48 \\
44 \\
38\end{array}$ & $\begin{array}{l}20 \\
18 \\
29 \\
42 \\
30 \\
15 \\
37 \\
29\end{array}$ & $\begin{array}{l}0 \\
0 \\
0 \\
0 \\
0 \\
0 \\
1 \\
0\end{array}$ & $\begin{array}{l}0 \\
0 \\
0 \\
0 \\
0 \\
1 \\
0 \\
0\end{array}$ & $\begin{array}{l}43 \\
17 \\
42 \\
32 \\
16 \\
35 \\
14 \\
31\end{array}$ & $\begin{array}{l}1 \\
0 \\
0 \\
0 \\
5 \\
0 \\
1 \\
1\end{array}$ \\
\hline Totaal & 33 & 21 & 10 & 23 & 2 & 12 & 1 \\
\hline
\end{tabular}


Tabel A1.3

Bestemming van schoolverlaters

\begin{tabular}{lccccc}
\hline Opleidingssector & studie & $\begin{array}{c}\text { LLW/ } \\
\text { in-serv } \\
\%\end{array}$ & $\begin{array}{c}\text { betald } \\
\text { werk } \\
\%\end{array}$ & werkloos & $\%$ \\
\hline
\end{tabular}

AVO

MAVO

HAVO

WWO

Totaal

$\begin{array}{ll}80 & 7 \\ 83 & 3 \\ 92 & 1 \\ 84 & 4\end{array}$

10
12
5
9

1
1
1
1

VBO

$\begin{array}{ll}\text { landbouw } & 67 \\ \text { techniek } & 42 \\ \text { economie } & 56 \\ \text { gezondheidszorg } & 58 \\ \text { Totaal } & 50\end{array}$

$\begin{array}{lrrrr}67 & 12 & 18 & 1 & 2 \\ 42 & 21 & 27 & 6 & 4 \\ 56 & 5 & 26 & 9 & 4 \\ 58 & 11 & 23 & 3 & 4 \\ 50 & 15 & 25 & 5 & 4\end{array}$

MBO-kort

$\begin{array}{lrrrrr}\text { oriënteren en schakelen } & 57 & 8 & 24 & 8 & 3 \\ \text { landbouw } & 9 & 7 & 71 & 13 & 7 \\ \text { techniek } & 14 & 15 & 60 & 5 & 4 \\ \text { economie } & 27 & 10 & 52 & 6 & 4 \\ \text { gezondheidszorg } & 31 & 18 & 41 & 7 & 4\end{array}$

\section{MBO-tussen en -lang}

$\begin{array}{ll}\text { landbouw } & 24 \\ \text { techniek } & 36 \\ \text { economie } & 31 \\ \text { gezondheidszorg } & 18 \\ \text { gedrag en maatschappij } & 35\end{array}$

$\begin{array}{lrlll}24 & 2 & 67 & 4 & 2 \\ 36 & 3 & 56 & 3 & 2 \\ 31 & 1 & 62 & 4 & 1 \\ 18 & 10 & 66 & 5 & 1 \\ 35 & 8 & 51 & 5 & 1 \\ 31 & 4 & 60 & 4 & 1\end{array}$

HBO

landbouw

onderwijs

techniek

economie

gezondheidszorg

gedrag en maatschappij

kunst en cultuur

Totaal

\begin{tabular}{rrrrr}
13 & $\mathrm{x}$ & 78 & 8 & 2 \\
12 & $\mathrm{x}$ & 80 & 6 & 2 \\
12 & $\mathrm{x}$ & 82 & 5 & 1 \\
15 & $\mathrm{x}$ & 81 & 3 & 1 \\
9 & $\mathrm{x}$ & 86 & 5 & 1 \\
10 & $\mathrm{x}$ & 80 & 8 & 2 \\
11 & $\mathrm{x}$ & 73 & 10 & 5 \\
12 & $\mathrm{x}$ & 80 & 6 & 2 \\
52 & 6 & 37 & 3 & 2 \\
\hline
\end{tabular}

$x=$ antwoordcategorie niet opgenomen

Toelichting

Vraag in de enquête: Geef [...] aan wat volgens $u$ het best past bij uw situatie. 
Tabel A2.1

Doorstroom van schoolverlaters naar het voltijd vervolgonderwijs

\begin{tabular}{|c|c|c|c|c|c|c|c|c|c|}
\hline Opleidingssector & MAVO & $\begin{array}{c}\text { HAVO } \\
\%\end{array}$ & $\begin{array}{c}\text { WWO } \\
\%\end{array}$ & $\begin{array}{r}\text { VBO } \\
\%\end{array}$ & $\begin{array}{c}\text { MBO- } \\
\text { kort } \\
\%\end{array}$ & $\begin{array}{c}\text { MBO } \\
\%\end{array}$ & $\begin{array}{r}\text { HBO } \\
\%\end{array}$ & $\begin{array}{l}\text { WO } \\
\%\end{array}$ & $\begin{array}{c}\text { overig } \\
\%\end{array}$ \\
\hline
\end{tabular}

AVO

MAVO

HAVO

WWO

Totaal

$\begin{array}{rrrrrrrrr}0 & 17 & 0 & 0 & 4 & 73 & 0 & 0 & 5 \\ 0 & 2 & 10 & 0 & 2 & 25 & 60 & 0 & 0 \\ 0 & 0 & 2 & 0 & 0 & 1 & 32 & 65 & 0 \\ 0 & 8 & 3 & 0 & 2 & 40 & 26 & 18 & 2\end{array}$

VBO

landbouw

techniek

economie

gezondheidszorg

Totaal

$\begin{array}{lllllllll}0 & 0 & 0 & 2 & 16 & 80 & 0 & 0 & 1 \\ 3 & 0 & 0 & 3 & 28 & 66 & 0 & 0 & 1 \\ 1 & 1 & 0 & 1 & 29 & 67 & 1 & 0 & 0 \\ 0 & 0 & 0 & 2 & 28 & 71 & 0 & 0 & 0 \\ 1 & 0 & 0 & 2 & 27 & 69 & 0 & 0 & 0\end{array}$

MBO-kort

oriënteren en schakelen

landbouw

techniek

economie

gezondheidszorg

Totaal

$\begin{array}{rrrrrrrrr}0 & 1 & 0 & 1 & 30 & 63 & 2 & 0 & 5 \\ 0 & 27 & 0 & 0 & 0 & 71 & 2 & 0 & 0 \\ 0 & 0 & 0 & 0 & 24 & 67 & 1 & 0 & 7 \\ 1 & 1 & 0 & 0 & 11 & 77 & 9 & 0 & 2 \\ 0 & 0 & 0 & 0 & 6 & 93 & 1 & 0 & 0 \\ 0 & 1 & 0 & 0 & 22 & 70 & 3 & 0 & 4\end{array}$

MBO-tussen en -lang

landbouw

techniek

economie

gezondheidszorg

gedrag en maatschappi

Totaal

$\begin{array}{lllllllll}0 & 1 & 0 & 0 & 3 & 27 & 69 & 0 & 0 \\ 0 & 0 & 0 & 0 & 2 & 15 & 82 & 0 & 0 \\ 0 & 0 & 0 & 0 & 3 & 12 & 84 & 0 & 0 \\ 0 & 2 & 0 & 0 & 4 & 18 & 76 & 0 & 0 \\ 0 & 0 & 0 & 0 & 1 & 8 & 91 & 0 & 0 \\ 0 & 1 & 0 & 0 & 2 & 14 & 83 & 0 & 0\end{array}$

HBO

landbouw

onderwijs

techniek

economie

gezondheidszorg

gedrag en maatschappij

kunst en cultuur

Totaal

$\begin{array}{lllllllll}0 & 0 & 0 & 0 & 0 & 0 & 46 & 54 & 0 \\ 0 & 0 & 0 & 0 & 0 & 1 & 49 & 49 & 0 \\ 0 & 0 & 0 & 0 & 0 & 0 & 51 & 49 & 0 \\ 0 & 0 & 0 & 0 & 0 & 0 & 21 & 78 & 0 \\ 0 & 0 & 0 & 0 & 0 & 0 & 42 & 58 & 0 \\ 0 & 0 & 0 & 0 & 0 & 1 & 28 & 71 & 0 \\ 0 & 0 & 0 & 0 & 0 & 1 & 84 & 16 & 0 \\ 0 & 0 & 0 & 0 & 0 & 0 & 42 & 58 & 0 \\ 0 & 5 & 2 & 0 & 7 & 41 & 29 & 14 & 2\end{array}$

Toelichting

Het gaat hier alleen om schoolverlaters die een voltijd vervolgopleiding zijn gaan volgen, ongeacht of zij dit vervolgonderwijs al dan niet met succes hebben verlaten. Voor de doorstroom naar het leerlingwezen of het inservice onderwijs wordt verwezen naar tabel 2.4. 
Tabel A2.2

Belangrijkste opleidingen van schoolverlaters die een voltijd vervolgopleiding zijn gaan volgen

MAVO

HAVO

MBO Administratie

MBO Sociaal-pedagogisch werker (AW/SW)

MBO Handel

HAVO

WWO

HBO Leraar basis-/speciaalonderwijs

MBO Administratie

VWO

WO Geneeskunde

WO Recht en openbare orde

WO Psychologie (ook OU)

WO Economie

\section{VBO landbouw}

MBO Veehouderij

MBO Groene ruimte

MBO Plantenteelt (en handel)

MBO Bloemschikken

MBO Sociaal-pedagogisch werker (AW/SW)

VBO techniek

MBO Elektrotechniek

MBO Bouwkunde

MBO Werktuigbouwkunde

VBO economie

MBO Administratie

MBO Handel

MBO Kort Administratie

MBO Economie

MBO Kort Handel

VBO gezondheidszorg

MBO Sociaal-pedagogisch werker (AW/SW)

MBO Verzorging

MBO Kort Verzorging

MBO Uiterlijke verzorging

MBO Kort Oriënteren en schakelen

MBO-kort oriënteren en schakelen

MBO Sociaal-pedagogisch werker (AW/SW)

MBO Verzorging

MBO Kort Handel

MBO Kort Administratie

MBO Uiterlijke verzorging 
Tabel A2.2 (vervolg)

Belangrijkste opleidingen van schoolverlaters die een voltijd vervolgopleiding zijn gaan volgen

MBO-kort landbouw

HAVO

MBO Politie

MBO Dierenverzorging en veterinaire ondersteuning

MBO Grafische techniek

MBO-kort techniek

MBO Elektrotechniek

MBO Bouwkunde

MBO Kort Installatietechniek

VHBO

MBO Bedrijfsmanagement motorvoertuigen

MBO Kort Bouwkunde

MBO Textielhandel

MBO Houtbewerking en woninginrichting

MBO-kort economie

MBO Administratie

MBO Handel

MBO-kort gezondheidszorg

MBO Verzorging

MBO Sociaal-pedagogisch werker (AW/SW)

MBO Verpleging

MBO Civiele en consumptief technische diensten

MBO tussen- en -lang landbouw

HBO Agrarische bedrijfskunde

HBO Veehouderij

HBO Tuinbouw

HBO Docent plantenteelt en verwerking

HBO Tuin- en landschapsinrichting

MBO-tussen en -lang techniek

HBO Elektrotechniek

HBO Bouwkunde

HBO Werktuigbouwkunde

HBO Technische bedrijfskunde

MBO-tussen en -lang economie

HBO Commerciele economie

HBO Bedrijfseconomie (ook OU)

HBO Opleiding voor management, economie en rech

HBO Facilitaire dienstverlening

MBO Administratie

MBO-tussen en -lang gezondheidszorg

HBO Opleiding tot verpleegkundige 
Tabel A2.2 (vervolg)

Belangrijkste opleidingen van schoolverlaters die een voltijd vervolgopleiding zijn gaan volgen

\section{MBO-tussen en -lang gedrag en maatschappij}

$\begin{array}{lr}\text { HBO Sociaal-pedagogische hulpverlening } & 29 \\ \text { HBO Leraar basis-/speciaalonderwijs } & 22 \\ \text { HBO Maatschappelijk werk en dienstverlening } & 13 \\ \text { HBO Personeel en arbeid } & 6\end{array}$

\section{HBO landbouw}

HBO Technische bedrijfskunde

HBO Masters-opl. Landbouw

WO Bedrijfskunde (ook OU)

WO Bodem, water en atmosfeer

HBO Masters-opl. Economie

WO Zoötechniek

HBO onderwijs

HBO Leraar basis-/speciaalonderwijs

WO Pedagogische wetenschappen

WO Onderwijskunde (ook OU)

HBO Leraar VO maatschappij 1-vak (2e gr.)

HBO techniek

HBO Technische bedrijfskunde

WO Bedrijfskunde (ook OU)

HBO Masters-opl. Techniek

WO Bouwkunde

\section{HBO economie}

WO Bedrijfseconomie

WO Bedrijfskunde (ook OU)

HBO Masters-opl. Economie

WO Nederlands recht (ook OU)

WO Economie

PDO Accountant

HBO gezondheidszorg

WO Gezondheidswetenschappen

HBO Masters-opl. Gezondheidszorg

WO Pedagogische wetenschappen

$\mathrm{HBO}$ Opleiding tot verpleegkundige

WO Bewegingswetenschappen

HBO Opleiding van kader in de gezondheidszorg

\section{HBO gedrag en maatschappij}

WO Pedagogische wetenschappen

WO Sociologie

WO Psychologie (ook OU)

HBO Masters-opl. Gedrag en maatschappij

WO Algemene sociale wetenschappen

WO Beleids- en organisatiewetenschappen

\section{HBO kunst en cultuur}

HBO Uitvoerend musicus

HBO 2e fase Autonome beeldende kunst

HBO Masters-opl. Kunst en cultuur 
Tabel A2.3

Oordeel van schoolverlaters over de aansluiting van de afgesloten opleiding met de voltijd vervolgopleiding en het percentage schoolverlaters dat deze vervolgopleiding achteraf bezien opnieuw zou kiezen

\begin{tabular}{ccccc}
\hline Opleidingssector & goed & $\begin{array}{c}\text { oordeel } \\
\text { vol- } \\
\text { doende } \\
\%\end{array}$ & matig & slecht \\
$\%$ & $\%$ & $\%$ & $\begin{array}{c}\text { opnieuw } \\
\text { kiezen } \\
\%\end{array}$ \\
\hline
\end{tabular}

AVO

MAVO

HAVO

WWO

Totaal

$\begin{array}{ll}43 & 36 \\ 36 & 39 \\ 45 & 40 \\ 42 & 38\end{array}$

$\begin{array}{ll}36 & 15 \\ 39 & 18 \\ 40 & 11 \\ 38 & 15\end{array}$

$\begin{array}{ll}6 & 89 \\ 6 & 86\end{array}$

89

94
89

VBO

landbouw

techniek

economie

gezondheidszorg

Totaal

$\begin{array}{lll}35 & 40 & \\ 38 & 36 & 14 \\ 40 & 32 & 21 \\ 40 & 39 & \\ 39 & 36 & \end{array}$

$\begin{array}{rr}18 & 6 \\ 14 & 12 \\ 21 & 8 \\ 12 & 8 \\ 16 & 9\end{array}$

$\mathbf{x}$
87
79
72
81

MBO-kort

oriënteren en schakelen

landbouw

techniek

economie

gezondheidszorg

Totaal

$\begin{array}{ll}46 & 39 \\ 11 & 11 \\ 36 & 28 \\ 38 & 35 \\ 51 & 29 \\ 43 & 36\end{array}$

$\begin{array}{ll}39 & \\ 11 & 44 \\ 28 & 29 \\ 35 & 15 \\ 29 & 14 \\ 36 & \end{array}$

$\begin{array}{rr}14 & 2 \\ 44 & 33 \\ 29 & 8 \\ 15 & 11 \\ 14 & 6 \\ 16 & 5\end{array}$

$x$
$x$
$x$
$x$
$x$
$x$

MBO-tussen en -lang

landbouw

techniek

economie

gezondheidszorg

gedrag en maatschappij

Totaal

$\begin{array}{rrrr}31 & 29 & 24 & 16 \\ 43 & 39 & 14 & 5 \\ 38 & 37 & 17 & 8 \\ 28 & 40 & 23 & 10 \\ 35 & 46 & 14 & 5 \\ 39 & 39 & 16 & 7\end{array}$

16
5
8
10
5
7

HBO

landbouw

onderwijs

techniek

economie

gezondheidszorg

gedrag en maatschappij

kunst en cultuur

Totaal

$\begin{array}{llll}59 & 26 & 13 & 2 \\ 51 & 34 & 11 & 3 \\ 52 & 32 & 12 & 4 \\ 50 & 34 & 11 & 5 \\ 47 & 40 & 10 & 3 \\ 44 & 35 & 15 & 5 \\ 53 & 24 & 16 & 7 \\ 51 & 33 & 12 & 4\end{array}$

$\begin{array}{ll}2 & \mathrm{x} \\ 3 & \mathrm{x} \\ 4 & \mathrm{x} \\ 5 & \mathrm{x} \\ 3 & \mathrm{x} \\ 5 & \mathrm{x} \\ 7 & \mathrm{x} \\ 4 & \mathrm{x}\end{array}$

Totaal

41

37

15

6

88

$\mathrm{x}=$ vraag niet opgenomen

Toelichting

Vragen in de enquête:

- Hoe vindt $u$ de aansluiting tussen uw [...] opleiding en deze vervolgopleiding?

- Zou u achteraf bezien deze vervolgopleiding opnieuw kiezen?

Het gaat hier alleen om schoolverlaters die een reguliere vervolgopleiding zijn gaan volgen. 
Tabel A2.4

Doorstroom van schoolverlaters naar het duale onderwijs

$\%$

MAVO

SVB

In-service Ziekenverzorgende

$\mathrm{OCH}$

In-service verpleegkundige A

L-OVD

Transport en logistiek

SVS

ECABO

OVDB

VEV

SOM

INNOVAM

GOC

SH\&M

LOBAS

SVK

LLW/In-service rest

SVO

In-service Z-verpleegkundige

HAVO

In-service verpleegkundige $A$

ECABO

In-service Z-verpleegkundige

INNOVAM

$\mathrm{OCH}$

OVDB

In-service Operatie-assistent

In-service rest

VEV

VOC-car

Transport en logistiek

LOBAS

GOC

\section{vwo}

In-service verpleegkundige $A$ in-service Laborant

$\mathrm{OCH}$

LLW rest

In-service Operatie-assistent

\section{VBO landbouw}

LOBAS
SBW
Transport en logistiek
L-OVD
SOM
OCH
SVB
SVK
OVDB


Tabel A2.4 (vervolg)

Doorstroom van schoolverlaters naar het duale onderwijs

\section{VBO techniek}

SOM

$\mathrm{OCH}$

INNOVAM

SOBEB

SVB

Transport en logistiek

SVS

VEV

INTECHNIUM

SH\&M

LLW rest

SVO

L-OVD

LLW/In-service rest

LOBAS

OVDB

sVK

17

13

13

BO economie

L-OVD

ECABO

SVK

INNOVAM

$\mathrm{OCH}$

VBO gezondheidszorg

SVK

L-OVD

39

$\mathrm{OCH}$

21

In-service Ziekenverzorgende

OVDB

Transport en logistiek

In-service Z-verpleegkundige

LLW rest

10

MBO-kort oriënteren en schakelen

$\mathrm{OCH}$

OVDB

ECABO

L-OVD

SVK

In-service verpleegkundige A

In-service Ziekenverzorgende

LLW/In-service rest

BO-kort landbouw

LOBAS
SVB
SBW
SVO
SOM
Transport en logistiek


Tabel A2.4 (vervolg)

Doorstroom van schoolverlaters naar het duale onderwijs

$\%$

MBO-kort techniek

INNOVAM

VEV

25

SOM

INTECHNIUM

SVB

LLW rest

SOBEB

SH\&M

ECABO

$\mathrm{OCH}$

GOC

L-OVD

11
8

8

3

3

3

2

MBO-kort economie

ECABO

$\mathrm{OCH}$

L-OVD

SVB

VEV

LLW rest

In-service Ziekenverzorgende

MBO-kort gezondheidszorg

OVDB

In-service Ziekenverzorgende

SVK

$\mathrm{OCH}$

ECABO

SOBEB

44

29

21

3

MBO-tussen en -lang landbouw

LOBAS

SOM

SBW

LLW rest

Transport en logistiek

SVS

ECABO

OVDB

In-service Ziekenverzorgende

VAPRO

VOC-car 
Tabel A2.4 (vervolg)

Doorstroom van schoolverlaters naar het duale onderwijs

MBO-tussen en -lang techniek

VEV
INNOVAM
SOM
ECABO
SVB
Transport en logistiek
INTECHNIUM
LLW rest
VOC-car
In-service Ziekenverzorgende
SBW

MBO-tussen en -lang economie

ECABO

Transport en logistiek

L-OVD

SVB

LLW rest

OVDB

LOBAS

SOM

SVO

VEV

VOC/BETEX

In-service Ziekenverzorgende

MBO-tussen en -lang gezondheidszorg

In-service Ziekenverzorgende

In-service verpleegkundige A

In-service Z-verpleegkundige

OVDB

In-service verpleegkundige $B$

SVK

$\mathrm{OCH}$

In-service rest

ECABO

LOBAS

In-service Operatie-assistent

SVB

SVS

LLW rest

LLW/In-service rest

SVGB 
Tabel A2.4 (vervolg)

Doorstroom van schoolverlaters naar het duale onderwijs

$\%$

MBO-tussen en -lang gedrag en maatschappij

In-service Z-verpleegkundige

In-service Ziekenverzorgende

In-service verpleegkundige $B$

In-service verpleegkundige $A$

OVDB

SVGB

L-OVD

SVO

LOBAS

VOC-ca

In-service rest 
Tabel A2.5

Oordeel van schoolverlaters over de aansluiting van de afgesloten opleiding met de duale vervolgopleiding en het percentage schoolverlaters dat deze duale vervolgopleiding achteraf bezien opnieuw zou kiezen

\begin{tabular}{|c|c|c|c|c|c|}
\hline Opleidingssector & $\begin{array}{c}\text { goed } \\
\%\end{array}$ & $\begin{array}{c}\text { oordeel } \\
\text { vol- } \\
\text { doende } \\
\%\end{array}$ & $\begin{array}{l}\text { matig } \\
\%\end{array}$ & $\begin{array}{c}\text { slecht } \\
\%\end{array}$ & $\begin{array}{c}\text { opnieuw } \\
\text { kiezen } \\
\%\end{array}$ \\
\hline
\end{tabular}

AVO

MAVO

HAVO

WWO

42
55
60
45

27
28
28
27

$19 \quad 13$

38

97

Totaal

$18 \quad 10$

VBO

landbouw

techniek

economie

gezondheidszorg

Totaal

$\begin{array}{ll}36 & 49 \\ 46 & 33 \\ 54 & 20 \\ 43 & 31 \\ 45 & 33\end{array}$

3

$14 \quad 7$

$12 \quad 14$

21

14

0
10

89

MBO-kort

oriënteren en schakelen

landbouw

techniek

economie

gezondheidszorg

Totaal

$\begin{array}{ll}46 & 38 \\ 62 & 12 \\ 41 & 33 \\ 34 & 39 \\ 43 & 46 \\ 40 & 37\end{array}$

$\begin{array}{rr}9 & 8 \\ 12 & 14 \\ 15 & 11 \\ 17 & 9 \\ 11 & 0 \\ 14 & 9\end{array}$

$\mathbf{x}$
80
53
75
77

MBO-tussen en -lang

\begin{tabular}{|c|c|c|c|c|}
\hline $\begin{array}{l}\text { landbouw } \\
\text { techniek } \\
\text { economie } \\
\text { gezondheidszorg } \\
\text { gedrag en maatschappij } \\
\text { Totaal }\end{array}$ & $\begin{array}{l}31 \\
34 \\
37 \\
53 \\
47 \\
43\end{array}$ & $\begin{array}{l}32 \\
31 \\
48 \\
32 \\
35 \\
34\end{array}$ & $\begin{array}{l}16 \\
23 \\
10 \\
10 \\
10 \\
14\end{array}$ & $\begin{array}{r}21 \\
12 \\
5 \\
5 \\
7 \\
8\end{array}$ \\
\hline Totaal & 51 & 27 & 15 & 7 \\
\hline
\end{tabular}

$\mathrm{x}=$ vraag niet opgenomen

Toelichting

Vragen in de enquête:

- Hoe vindt $u$ de aansluiting tussen uw [...] opleiding en deze vervolgopleiding?

- Zou $u$ achteraf bezien deze vervolgopleiding opnieuw kiezen?

Het gaat hier alleen om schoolverlaters die een opleiding in het leerlingwezen of het in-service onderwijs zijn gaan volgen. 
Tabel A3.1

Werkloosheid en gemiddelde intredewerkloosheid van schoolverlaters die zich aanbieden op de arbeidsmarkt

\begin{tabular}{lcc}
\hline Opleidingssector & $\begin{array}{c}\text { werkloosheid } \\
\%\end{array}$ & $\begin{array}{c}\text { intredewerkloosheid } \\
\text { maanden }\end{array}$ \\
\hline
\end{tabular}

AVo

MAVO

HAVO

WWO

10

1100,5

Totaal

VBO

landbouw

techniek

economie

gezondheidszorg

Totaal

MBO-kort

oriënteren en schakelen

landbouw

techniek

economie

gezondheidszorg

Totaal

MBO-tussen en -lang

landbouw
techniek
economie
gezondheidszorg
gedrag en maatschappij
Totaal

$4 \quad 0,7$

$\begin{array}{ll}4 & 0,9 \\ 6 & 0,9\end{array}$

$8 \quad 1,1$

$\begin{array}{rr}8 \\ 10 & 1,3 \\ 7 & 1,0\end{array}$

Totaal

HBO

landbouw

onderwijs

techniek

economie

gezondheidszorg

gedrag en maatschappij

kunst en cultuur

Totaal

9

$8-1,4$

6

40,8

9

9
18
7

Totaal

\section{Toelichting}

Het werkloosheidspercentage betreft hier de werkloze beroepsbevolking: schoolverlaters zonder werk (of met werk minder dan 12 uur per week) die minstens 12 uur per week willen werken, daarvoor direct beschikbaar zijn en bovendien actief zoeken naar werk (ongeacht of men bij een arbeidsbureau staat ingeschreven). De intredewerkloosheid betreft het aantal maanden dat schoolverlaters zichzelf als werkloos beschouwen.

Het betreft hier alleen schoolverlaters die tot de beroepsbevolking behoren en zichzelf niet in de eerste plaats als student beschouwen. 


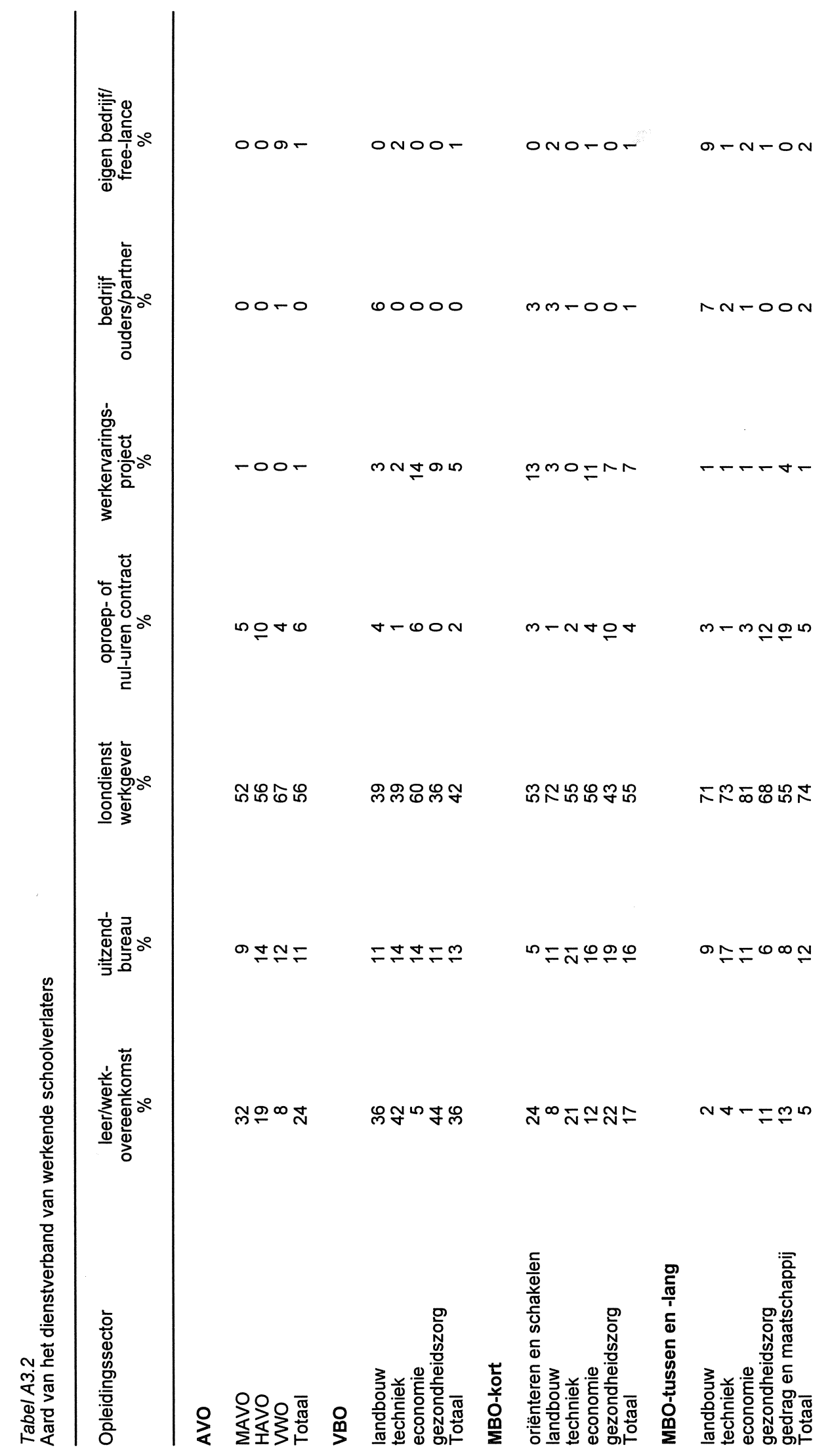




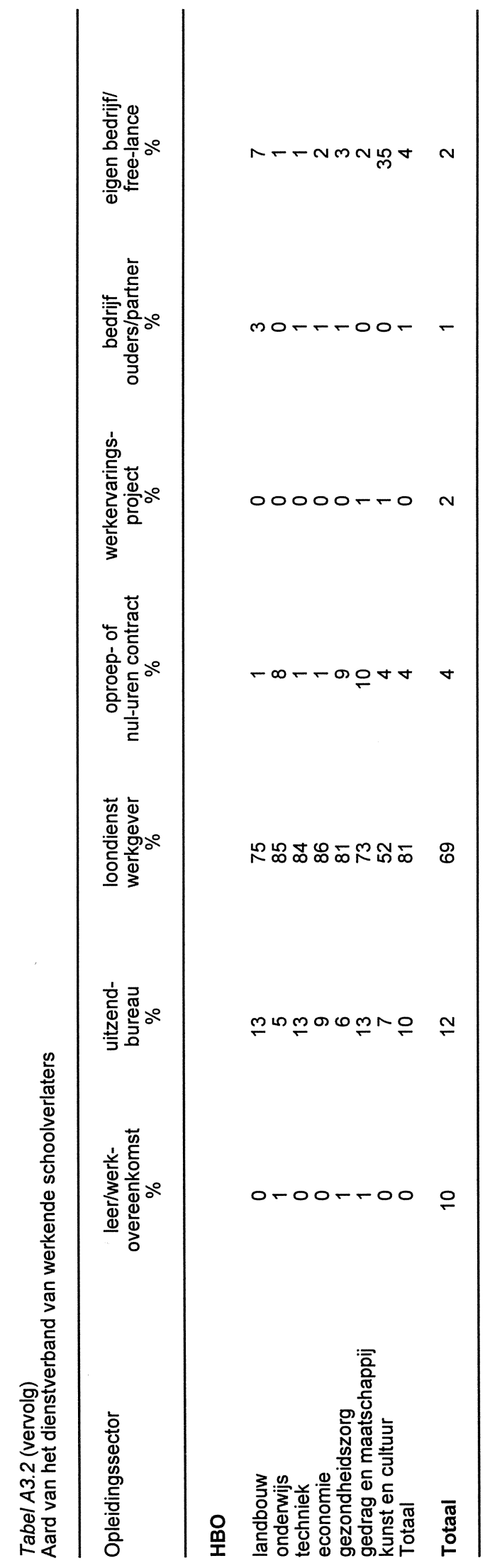


Tabel A3.3

Percentage werkende schoolverlaters met een flexibele aanstelling

Opleidingssector

AVo

MAVO

HAVO

WWO

Totaal

vBO

landbouw

techniek

economie

gezondheidszorg

MBO-kort

oriënteren en schakelen

landbouw

techniek

economie

gezondheidszorg

32

Totaal

MBO-tussen en -lang

$\begin{array}{lr}\text { landbouw } & 27 \\ \text { techniek } & 25 \\ \text { economie } & 25 \\ \text { gezondheidszorg } & 28 \\ \text { gedrag en maatschappij } & 36 \\ \text { Totaal } & 26\end{array}$

HBO

landbouw

onderwijs

techniek

economie

gezondheidszorg

gedrag en maatschappij

$\begin{array}{ll}\text { kunst en cultuur } & 21 \\ \text { Total } & 23\end{array}$

Totaal 26

Toelichting

Een flexibele aanstelling betreft een aanstelling als uitzendkracht, oproepkracht e.d. of een aanstelling in tijdelijke dienst met een contract korter dan een jaar. 


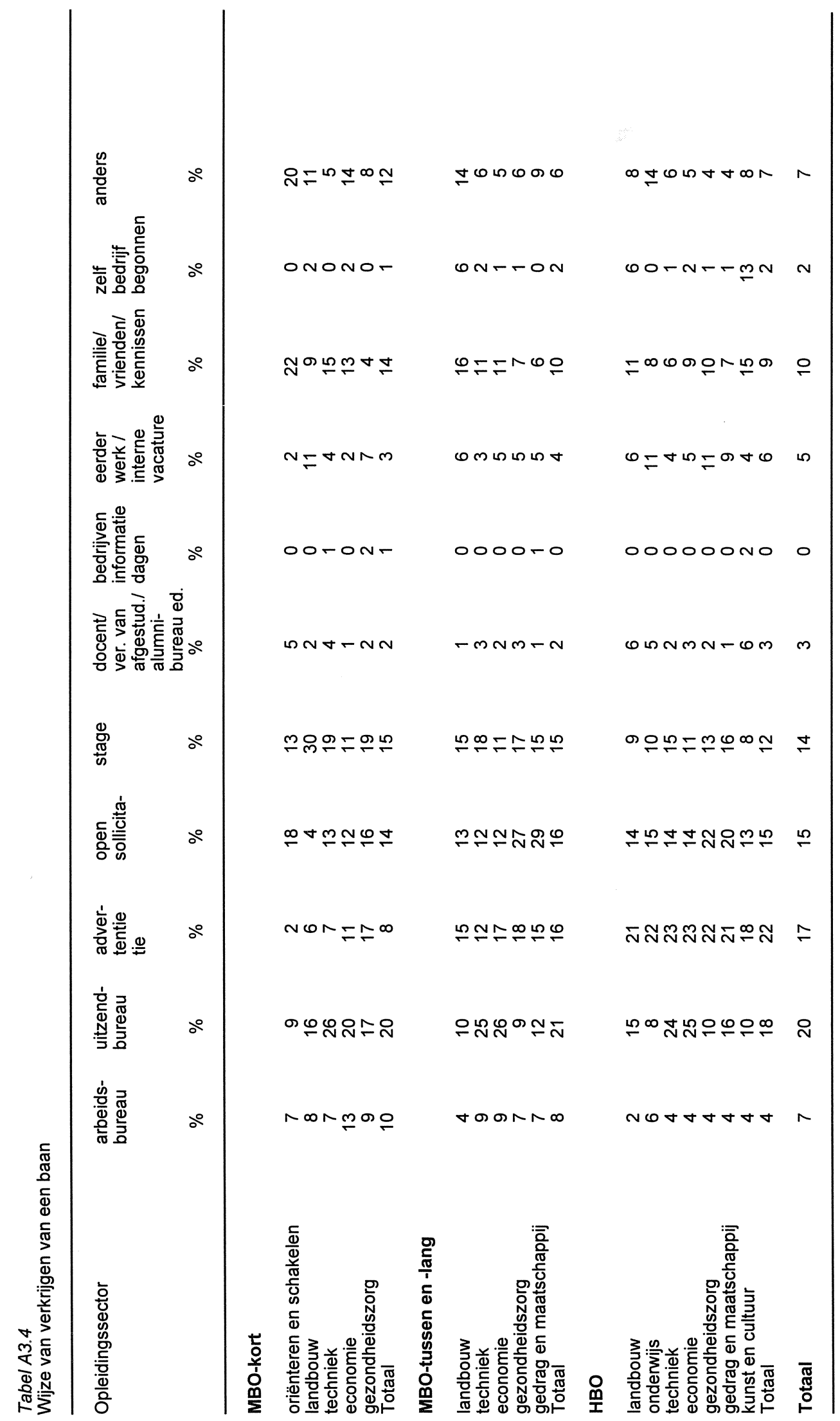


Tabel A3.5

Belangrijkste bedrijfsgroepen waarin schoolverlaters werkzaam zijn

MAVO

Ov. gespec. detailh. in winke

Niet-gespec. detailh. in winkel

Gespec. detailh. voed.-/genotmid. in winkel

Burgerl./utilit.;grond-/water-/wegenb. (excl. grondverz.)

Welzijnszorg

Vervoer over weg

Gezondheidszorg

HAVO

Ov. gespec. detailh. in winkel

Gezondheidszorg

Niet-gespec. detailh. in winkel

Geldscheppende financ. instell.

Welzijnszorg

Restaurants/cafetaria's/snackbars ed

VWO

Rechtsk. dienstverl./account./belastingconsul./holdings ed

Grooth. ov. consumentenart.

Reiniging gebouwen/transportmid. ed

Gezondheidszorg

Overig amusement/kunst

\section{VBO landbouw}

Ov. gespec. detailh. in winkel

Dienstverl. tbv landb. (excl. veterin.dienst.)

Burgerl./utilit.;grond-/water-/wegenb. (excl. grondverz.)

Niet-gespec. detailh. in winkel

Vervoer over weg

Akker-/tuinbouw

Restaurants/cafetaria's/snackbars ed

\section{VBO techniek}

Burgerl./utilit.;grond-/water-/wegenb. (excl. grondverz.)

Bouwinstallatie

Afwerken gebouwen

Restaurants/cafetaria's/snackbars ed

Overheidsdienst.

Handel in/repar. auto's (1)

Vervaard. ov. voedingsmid.

\section{VBO economie}

Niet-gespec. detailh. in winkel

Ov. gespec. detailh. in winkel

Gespec. detailh. voed.-/genotmid. in winkel

Ov. dienstverlening

VBO gezondheidszorg

Ov. dienstverlening

Welzijnszorg

Niet-gespec. detailh. in winkel

Restaurants/cafetaria's/snackbars ed

Grooth. ov. consumentenart. 
Tabel A3.5 (vervolg)

Belangrijkste bedrijfsgroepen waarin schoolverlaters werkzaam zijn

\section{MBO-kort oriënteren en schakelen}

Niet-gespec. detailh. in winkel

Welzijnszorg

Restaurants/cafetaria's/snackbars ed

Ov. gespec. detailh. in winkel

Gezondheidszorg

Vervaard. med. appar./instrum./orthop./prothese-art.

Afwerken gebouwen

Grooth. intermediaire goederen (excl. agrar.)/afval/schroot

Detailh. farmac./med. art./parfum/cosmet. in winkel

Vervoer over weg

Basisonderwijs voor leerplichtingen/speciaal onderwijs

MBO-kort landbouw

Akker-/tuinbouw

Dienstverl. tbv landb. (excl. veterin.dienst.)

Niet-gespec. detailh. in winkel

Logies-/maaltijden-/drankenverstrek.

Sport

Fokken/houden dieren

Ov. gespec. detailh. in winkel

Vervaard. elektr. componenten

MBO-kort techniek

Bouwinstallatie

Burgerl./utilit.;grond-/water-/wegenb. (excl. grondverz.)

Handel in/repar. auto s (1)

Overheidsdienst.

MBO-kort economie

Ov. gespec. detailh. in winkel

Niet-gespec. detailh. in winkel

Restaurants/cafetaria's/snackbars ed

Openbaar bestuur

MBO-kort gezondheidszorg

Welzijnszorg

Ov. dienstverlening

Niet-gespec. detailh. in winkel

MBO-tussen en -lang landbouw

Akker-/tuinbouw

Dienstverl. tbv landb. (excl. veterin.dienst.)

Ov. gespec. detailh. in winke

Fokken/houden dieren

MBO-tussen en -lang techniek

Bouwinstallatie

Burgerl./utilit.;grond-/water-/wegenb. (excl. grondverz.)

Architecten-/ingenieurs-/ov. techn.ontw.-/teken-/adviesbur.

Drukkerijen/aanverwante activ. 
Tabel A3.5 (vervolg)

Belangrijkste bedrijfsgroepen waarin schoolverlaters werkzaam zijn

\section{MBO-tussen en -lang economie}

Ov. gespec. detailh. in winkel

Hotels/pensions/conferentie-oorden

Rechtsk. dienstverl./account./belastingconsul./holdings ed

Niet-gespec. detailh. in winkel

Reisorgan./-bemid.;informatieverstrek. op gebied toerisme

MBO-tussen en -lang gezondheidszorg

Welzijnszorg

Gezondheidszorg

Detailh. farmac./med. art./parfum/cosmet. in winkel

Ov. gespec. detailh. in winkel

MBO-tussen en -lang gedrag en maatschappij

Welzijnszorg

Basisonderwijs voor leerplichtingen/speciaal onderwijs

\section{HBO landbouw}

Architecten-/ingenieurs-/ov. techn.ontw.-/teken-/adviesbur.

Openbaar bestuur

Akker-/tuinbouw

Fokken/houden dieren

\section{HBO onderwijs}

Basisonderwijs voor leerplichtingen/speciaal onderwijs

Voortgezet onderwijs

Ov. dienstverlening

\section{HBO techniek}

Adviesbur. op gebied automat./systeemh.

Architecten-/ingenieurs-/ov. techn.ontw.-/teken-/adviesbur.

Burgerl./utilit.;grond-/water-/wegenb. (excl. grondverz.)

\section{HBO economie}

Rechtsk. dienstverl./account./belastingconsul./holdings ed Geldscheppende financ. instell.

Uitzendbur./uitleenbedr./arbeidsbemid./testen/werven/select.

Adviesbur. op gebied automat./systeemh.

HBO gezondheidszorg

Gezondheidszorg

Welzijnszorg

HBO gedrag en maatschappij

Welzijnszorg

Gezondheidszorg

Uitzendbur./uitleenbedr./arbeidsbemid./testen/werven/select. Verpl. soc. verzekeringen 
Tabel A3.5 (vervolg)

Belangrijkste bedrijfsgroepen waarin schoolverlaters werkzaam zijn

$\%$

\section{HBO kunst en cultuur}

Overig amusement/kunst

Reklamebureaus ed

Ov. zakelijke dienstverl. n.e.g.

Ov. gespec. detailh. in winkel

Voortgezet onderwijs

Toelichting

De bedrijven waarin de schoolverlaters werkzaam zijn, zijn geclassificeerd volgens de Standaard Bedrijfs Indeling van het CBS. Op het hier gepresenteerde niveau van bedrijfsgroepen worden in totaal 211 categorieën onderscheiden.

In de tabel zijn alleen die bedrijfsgroepen weergegeven, waarin ten minste $5 \%$ van de schoolverlaters werkzaam zijn. 
Tabel A3.6

Belangrijkste beroepsgroepen waarin schoolverlaters werkzaam zijn

\title{
MAVO
}

Verkopers

Hulpkrachten horeca en verzorging

Interieurverzorger

Vakkenvuller

Kantoorhulpen, inpakkers en colporteurs

Agrarische arbeider

\section{HAVO}

\author{
Verkopers \\ Hulpkrachten horeca en verzorging \\ Interieurverzorger \\ Vakkenvuller \\ Receptionisten en administratieve employés \\ Agrarische arbeider
}

\section{VWO}

Verkopers

Hulpkrachten horeca en verzorging

Interieurverzorger

Vakkenvuller

Receptionisten en administratieve employés

\section{VBO landbouw}

Agrarische arbeider

Verkopers

Hulpkrachten horeca en verzorging

Interieurverzorger

\section{VBO techniek}

Bouwvakkers

Hulpkrachten horeca en verzorging

Verkopers

Metaalarbeiders

Laders en lossers

Assembleurs

Chauffeurs

\section{VBO economie}

Verkopers

Hulpkrachten horeca en verzorging

Receptionisten en administratieve employés

VBO gezondheidszorg

Hulpkrachten horeca en verzorging

Verkopers

Interieurverzorger

Agrarische arbeider

Kantoorhulpen, inpakkers en colporteurs

Vakkenvuller

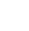

\section{MBO-kort oriënteren en schakelen}

\section{Verkopers}

Hulpkrachten horeca en verzorging

Interieurverzorger

Verpleeghulpen en leerling-verpleegkundigen 
Tabel A3.6 (vervolg)

Belangrijkste beroepsgroepen waarin schoolverlaters werkzaam zijn

\section{MBO-kort landbouw}

Agrarische arbeider

Verkopers

Interieurverzorger

Agrarische bedrijfshoofden

Agrarische vakkrachten

Sportinstructeurs

Laboranten

Bedrijfshoofden horeca

Productiemedewerker

MBO-kort techniek

Aannemers en installateurs

Monteurs

Elektromonteurs

Laders en lossers

Bouwvakkers

Bankwerkers en lassers

Metaalarbeiders

BBO-kort economie

Verkopers

Receptionisten en administratieve employés

Hulpkrachten horeca en verzorging

Boekhouders en secretaresses

MBO-kort gezondheidszorg

Verzorgend personeel

Hulpkrachten horeca en verzorging

Verkopers

Verpleeghulpen en leerling-verpleegkundigen

Interieurverzorger

BBO-tussen en -lang landbouw

Agrarische arbeider

Verkopers

Agrarische bedrijfshoofden

MBO-tussen en -lang techniek

Monteurs

Aannemers en installateurs

Elektromonteurs

Verkopers

\section{MBO-tussen en -lang economie}

Verkopers

Boekhouders en secretaresses

Receptionisten en administratieve employés

Commercieel employes

Hulpkrachten horeca en verzorging

Winkeliers 
Tabel A3.6 (vervolg)

Belangrijkste beroepsgroepen waarin schoolverlaters werkzaam zijn

\title{
MBO-tussen en -lang gezondheidszorg
}

Verzorgend personeel

Verplegenden en doktersassistenten

Verkopers

Verpleeghulpen en leerling-verpleegkundigen

Hulpkrachten horeca en verzorging

Apothekersassistenten en medisch laboranten

Ziekenverzorgenden

Activiteitenbegeleiders en medewerkers arbeidsbemiddeling

MBO-tussen en -lang gedrag en maatschappij

$\begin{array}{lr}\text { Verzorgend personeel } & 34 \\ \text { Hulpkrachten horeca en verzorging } & 18 \\ \text { Verkopers } & 13 \\ \text { Activiteitenbegeleiders en medewerkers arbeidsbemiddeling } & 12 \\ \text { Interieurverzorger } & 5\end{array}$

\section{HBO landbouw}

Milieuhygienisten en agrarisch vertegenwoordigers

Agrarische bedrijfshoofden

Commercieel medewerkers

Commercieel employes

Organisatie-adviseurs

HBO onderwijs

Leraar basisonderwijs

Docenten talen en expressie

\section{HBO techniek}

Systeemanalisten

Werktuigbouwkundig ontwerpers en hoofden technische dienst

Architecten en bouwkundig projectleiders

Technisch systeemanalisten

Technisch-bedrijfskundig medewerkers

\section{HBO economie}

\author{
Assistent accountants \\ Commercieel medewerkers \\ Commercieel employes \\ Boekhouders en secretaresses \\ Systeemanalisten \\ Activiteitenbegeleiders en medewerkers arbeidsbemiddeling
}

\section{HBO gezondheidszorg}

Therapeuten en verpleegkundigen

Verzorgend personeel

Verplegenden en doktersassistenten

HBO gedrag en maatschappij

Sociaal-cultureel werkers

Activiteitenbegeleiders en medewerkers arbeidsbemiddeling 
Tabel A3.6 (vervolg)

Belangrijkste beroepsgroepen waarin schoolverlaters werkzaam zijn

HBO kunst en cultuur

Kunstenaars

Docenten talen en expressie

44

\section{Toelichting}

De beroepen waarin de schoolverlaters werkzaam zijn, zijn geclassificeerd volgens de Standaard Beroepenclassificatie 1992 van het CBS. Binnen de elementaire beroepen is hierbij door het ROA een nader onderscheid gemaakt. Bovendien zijn de namen van de beroepen verduidelijkt. Op het hier gepresenteerde niveau van beroepsgroepen worden in totaal 127 categorieën onderscheiden.

In de tabel zijn alleen die beroepsgroepen weergegeven, waarin ten minste $5 \%$ van de schoolverlaters werkzaam zijn. 
Tabel A3. 7

Grootte van de organisatie waarin schoolverlaters werkzaam zijn

\begin{tabular}{|c|c|c|c|c|c|}
\hline Opleidingssector & $\begin{array}{c}1 \text { pers } \\
\%\end{array}$ & $\begin{array}{c}2 \mathrm{t} / \mathrm{m} 9 \\
\text { pers } \\
\%\end{array}$ & $\begin{array}{l}10 \mathrm{t} / \mathrm{m} 99 \\
\text { pers } \\
\%\end{array}$ & $\begin{array}{c}100 \mathrm{t} / \mathrm{m} \\
999 \text { pers } \\
\%\end{array}$ & $\begin{array}{c}>=1000 \\
\text { pers } \\
\%\end{array}$ \\
\hline
\end{tabular}

\section{MBO-kort}

$\begin{array}{llllrr}\text { oriënteren en schakelen } & 0 & 28 & 60 & 8 & 5 \\ \text { landbouw } & 2 & 45 & 32 & 4 & 16 \\ \text { techniek } & 0 & 21 & 50 & 20 & 10 \\ \text { economie } & 1 & 18 & 46 & 15 & 20 \\ \text { gezondheidszorg } & 2 & 21 & 36 & 27 & 14 \\ \text { Totaal } & 0 & 22 & 48 & 16 & 14\end{array}$

MBO-tussen en -lang

landbouw
techniek
economie
gezondheidszorg
gedrag en maatschappij

$\begin{array}{lll}6 & 48 & 29 \\ 1 & 16 & 41 \\ 1 & 16 & 39 \\ 1 & 21 & 28 \\ 1 & 11 & 41 \\ 1 & 18 & 37\end{array}$

$\begin{array}{rrr}29 & 9 & 7 \\ 41 & 23 & 20 \\ 39 & 24 & 21 \\ 28 & 33 & 16 \\ 41 & 35 & 13 \\ 37 & 25 & 18\end{array}$

HBO

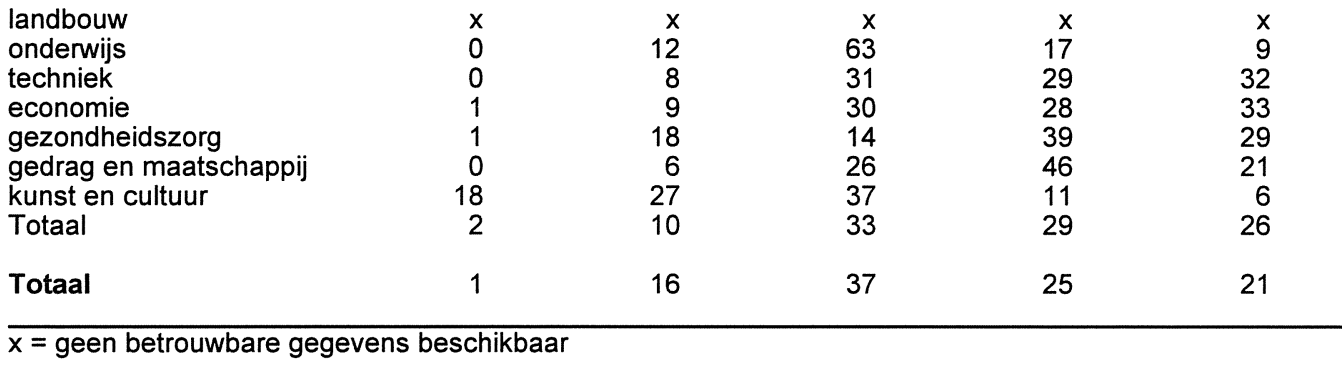

Toelichting

Vraag in de enquête: Hoeveel mensen werken er bij de organisatie of het bedrijf waar u werkzaam bent. Het gaat hier om alle werknemers van het totale concern (hoofd- en nevenvestigingen samen). 
Tabel A3. 8

Beloning van werkende schoolverlaters

\begin{tabular}{lcc}
\hline Opleidingssector & $\begin{array}{c}\text { gemiddeld } \\
\text { bruto maandloon } \\
\text { guldens }\end{array}$ & $\begin{array}{c}\text { gemiddeld } \\
\text { bruto uurloon } \\
\text { guldens }\end{array}$ \\
\hline
\end{tabular}

AVo

MAVO

$\begin{array}{ll}1.218 & 8,27\end{array}$

HAVO

1.334

9,48

WWO

1.825

9,48
11,29

Totaal

1.340

9,12

VBO

landbouw

techniek

$1.146 \quad 8,00$

$1.252 \quad 8,42$

$1.231 \quad 8,34$

economie

1.000

8,34
7,04

Totaal

1.196

8,13

MBO-kort

oriënteren en schakelen

1.219

1.902

2.034

1.724

1.332

1.723

8,22

11,56

techniek

economie

gezondheidszorg

11,82

11,23

9,70

10,86

\section{MBO-tussen en -lang}

$\begin{array}{llr}\text { landbouw } & 2.213 & 13,63 \\ \text { techniek } & 2.516 & 14,93 \\ \text { economie } & 2.158 & 13,33 \\ \text { gezondheidszorg } & 1.890 & 13,32 \\ \text { gedrag en maatschappij } & 1.813 & 13,24 \\ \text { Totaal } & 2.212 & 13,85 \\ \text { HBO } & & \\ & & \\ \text { landbouw } & 3.148 & 18,60 \\ \text { onderwijs } & 2.821 & 19,25 \\ \text { techniek } & 3.393 & 19,69 \\ \text { economie } & 3.231 & 19,16 \\ \text { gezondheidszorg } & 2.969 & 20,87 \\ \text { gedrag en maatschappij } & 2.728 & 18,96 \\ \text { kunst en cultuur } & 2.119 & 17,78 \\ \text { Totaal } & 3.084 & 19,30 \\ & & \\ \text { Totaal } & 2.298 & 14,50\end{array}$

\section{Toelichting}

Dit betreft het bruto inkomen in de baan waarin men het hoogste aantal uren werkt. Dit is inclusief toeslagen voor ploegendienst, fooien, provisie e.d., maar exclusief inkomen uit overwerk, vakantiegeld, 13e maand, uitkering, e.d. 
Tabel A3.9

Vereist opleidingsniveau voor de huidige functie volgens de schoolverlaters en de werkgever

\begin{tabular}{|c|c|c|c|c|c|c|}
\hline \multirow[t]{2}{*}{ Opleidingssector } & \multicolumn{3}{|c|}{ volgens de schoolverlater } & \multicolumn{3}{|c|}{ volgens de werkgever } \\
\hline & $\underset{\%}{\text { lager }}$ & $\begin{array}{c}\text { zelfde } \\
\%\end{array}$ & $\underset{\%}{\text { hoger }}$ & $\begin{array}{c}\text { lager } \\
\%\end{array}$ & $\begin{array}{c}\text { zelfde } \\
\%\end{array}$ & hoge \\
\hline \multicolumn{7}{|l|}{ AVO } \\
\hline $\begin{array}{l}\text { MAVO } \\
\text { HAVO } \\
\text { WWO } \\
\text { Totaal }\end{array}$ & $\begin{array}{l}18 \\
50 \\
35 \\
31\end{array}$ & $\begin{array}{l}71 \\
31 \\
59 \\
55\end{array}$ & $\begin{array}{r}12 \\
19 \\
6 \\
13\end{array}$ & $\begin{array}{l}20 \\
51 \\
42 \\
33\end{array}$ & $\begin{array}{l}72 \\
32 \\
51 \\
55\end{array}$ & $\begin{array}{r}8 \\
16 \\
7 \\
11\end{array}$ \\
\hline
\end{tabular}

VBO

landbouw

techniek

economie

gezondheidszorg

Totaal

$\begin{array}{rl}x & \\ 25 & 68 \\ 25 & 58 \\ 20 & 68 \\ 24 & 67\end{array}$

$\begin{array}{rrrrr}\mathbf{x} & \mathbf{x} & 26 & 71 & 3 \\ 68 & 7 & 27 & 66 & 8 \\ 58 & 17 & 15 & 58 & 27 \\ 68 & 12 & 23 & 65 & 12 \\ 67 & 10 & 24 & 65 & 11\end{array}$

MBO-kort

\begin{tabular}{|c|c|c|c|c|c|}
\hline $\begin{array}{l}\text { oriënteren en schakelen } \\
\text { landbouw } \\
\text { techniek } \\
\text { economie } \\
\text { gezondheidszorg } \\
\text { Totaal }\end{array}$ & $\begin{array}{l}83 \\
50 \\
46 \\
48 \\
59 \\
54\end{array}$ & $\begin{array}{r}5 \\
23 \\
36 \\
32 \\
31\end{array}$ & $\begin{array}{l}12 \\
27 \\
19 \\
20 \\
10\end{array}$ & $\begin{array}{l}87 \\
47 \\
46 \\
49 \\
56 \\
55\end{array}$ & $\begin{array}{r}5 \\
15 \\
33 \\
28 \\
29 \\
26\end{array}$ \\
\hline
\end{tabular}

MBO-tussen en -lang

\begin{tabular}{|c|c|c|c|c|c|}
\hline $\begin{array}{l}\text { landbouw } \\
\text { techniek } \\
\text { economie } \\
\text { gezondheidszorg } \\
\text { gedrag en maatschappij } \\
\text { Totaal }\end{array}$ & $\begin{array}{l}44 \\
30 \\
35 \\
31 \\
24 \\
32\end{array}$ & $\begin{array}{l}56 \\
68 \\
64 \\
68 \\
74 \\
66\end{array}$ & $\begin{array}{l}0 \\
2 \\
2 \\
1 \\
2 \\
1\end{array}$ & $\begin{array}{l}47 \\
26 \\
31 \\
34 \\
29 \\
30\end{array}$ & $\begin{array}{l}53 \\
72 \\
67 \\
66 \\
69 \\
68\end{array}$ \\
\hline
\end{tabular}

HBO

\begin{tabular}{|c|c|c|c|c|c|c|}
\hline $\begin{array}{l}\text { landbouw } \\
\text { onderwijs } \\
\text { techniek } \\
\text { economie } \\
\text { gezondheidszorg } \\
\text { gedrag en maatschappij } \\
\text { kunst en cultuur } \\
\text { Totaal }\end{array}$ & $\begin{array}{r}35 \\
17 \\
27 \\
34 \\
17 \\
39 \\
\times \\
29\end{array}$ & $\begin{array}{r}63 \\
83 \\
72 \\
65 \\
83 \\
61 \\
\times \\
70\end{array}$ & $\begin{array}{l}2 \\
0 \\
1 \\
1 \\
0 \\
0 \\
x \\
1\end{array}$ & $\begin{array}{l}33 \\
16 \\
19 \\
24 \\
18 \\
42 \\
37 \\
24\end{array}$ & $\begin{array}{l}66 \\
84 \\
80 \\
76 \\
82 \\
58 \\
40 \\
74\end{array}$ & $\begin{array}{r}1 \\
0 \\
1 \\
1 \\
0 \\
0 \\
22 \\
2\end{array}$ \\
\hline Totaal & 32 & 63 & 5 & 30 & 64 & 5 \\
\hline
\end{tabular}

$x=$ vraag niet opgenomen

Toelichting

Vragen in de enquête.

- Welk opleidingsniveau is volgens uzelf voor deze functie minimaal vereist?

- Welk opleidingsniveau werd door uw werkgever voor deze functie minimaal vereist? 
Tabel A3.10

Vereiste opleidingsrichting voor de huidige functie volgens de schoolverlaters en de werkgever

\begin{tabular}{|c|c|c|c|c|c|c|}
\hline \multirow[t]{2}{*}{ Opleidingssector } & \multicolumn{3}{|c|}{ volgens de schoolverlater } & \multicolumn{3}{|c|}{ volgens de werkgever } \\
\hline & $\begin{array}{l}\text { eigenl } \\
\text { verwante } \\
\text { richting } \\
\%\end{array}$ & $\begin{array}{c}\text { andere } \\
\text { richting } \\
\%\end{array}$ & $\begin{array}{c}\text { geen } \\
\text { richting } \\
\%\end{array}$ & $\begin{array}{l}\text { eigen/ } \\
\text { verwante } \\
\text { richting } \\
\%\end{array}$ & $\begin{array}{c}\text { andere } \\
\text { richting } \\
\%\end{array}$ & $\begin{array}{c}\text { geen } \\
\text { richting } \\
\%\end{array}$ \\
\hline
\end{tabular}

VBO

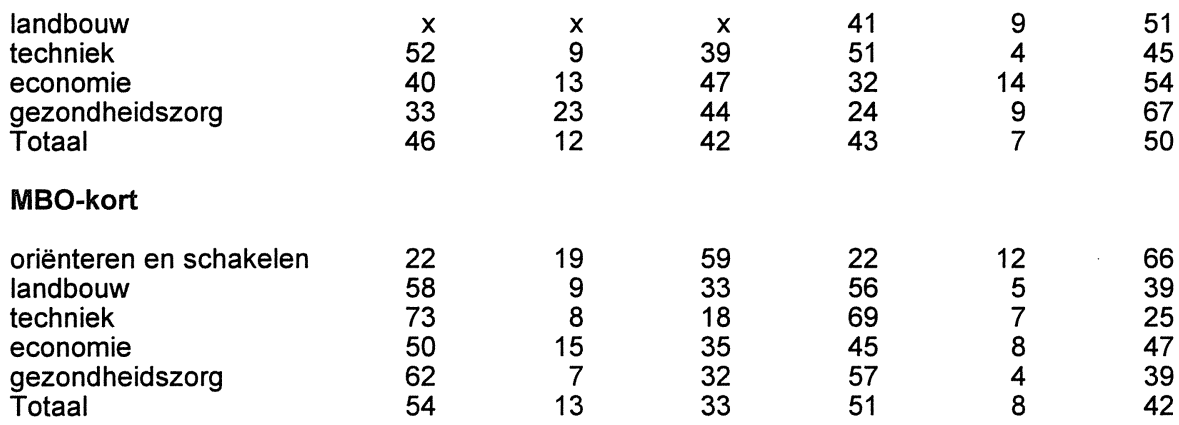

MBO-tussen en -lang

$\begin{array}{lrrrrrr}\text { landbouw } & 65 & 8 & 27 & 58 & 5 & 37 \\ \text { techniek } & 83 & 8 & 10 & 80 & 4 & 16 \\ \text { economie } & 68 & 10 & 23 & 63 & 5 & 31 \\ \text { gezondheidszorg } & 80 & 6 & 14 & 75 & 4 & 22 \\ \text { gedrag en maatschappij } & 77 & 5 & 17 & 72 & 4 & 24 \\ \text { Totaal } & 75 & 8 & 17 & 71 & 5 & 25\end{array}$

HBO

\begin{tabular}{|c|c|c|c|c|c|}
\hline landbouw & 77 & 7 & 16 & 74 & 6 \\
\hline onderwijs & 85 & 4 & 10 & 83 & 4 \\
\hline techniek & 86 & 5 & 10 & 83 & 4 \\
\hline economie & 78 & 6 & 15 & 72 & 5 \\
\hline gezondheidszorg & 95 & 2 & 3 & 94 & 2 \\
\hline gedrag en maatschappij & 83 & 6 & 11 & 79 & 6 \\
\hline kunst en cultuur & $x$ & $\mathrm{x}$ & $x$ & 71 & 5 \\
\hline Totaal & 83 & 5 & 12 & 79 & 5 \\
\hline Totaal & 71 & 8 & 20 & 68 & 5 \\
\hline
\end{tabular}

$x=$ vraag niet opgenomen

Toelichting

Vragen in de enquête

- Welke opleidingsrichting is volgens uzelf voor deze functie vereist?

- Welke opleidingsrichting werd door uw werkgever voor deze functie vereist? 
Tabel A3.11

Gewenste en feitelijke wekelijkse arbeidsduur van werkende schoolverlaters

\begin{tabular}{ccc}
\hline Opleidingssector & $\begin{array}{c}\text { gewenste wekelijkse } \\
\text { arbeidsduur } \\
\text { uren }\end{array}$ & $\begin{array}{c}\text { feitelijke wekelijkse } \\
\text { arbeidsduur } \\
\text { uren }\end{array}$ \\
\hline
\end{tabular}

AVo

MAVO

35,9

33,8

HAVO

33,9

33,3

32,8

Totaal

34,9

33,6

VBO

landbouw

38,1

techniek

38,1
37,5
36,7

35,9

35,3

economie

37,2

32,4

Totaal

34,1

\section{MBO-kort}

oriënteren en schakelen

landbouw

techniek

40,0

39,1

37,6

economie

35,5

37,5

34,3

40,4

39,1

35,0

gezondheidszorg

31,4

Totaal

36,0

\section{MBO-tussen en -lang}

$\begin{array}{ll}\text { landbouw } & 41 \\ \text { techniek } & 39 \\ \text { economie } & 38 \\ \text { gezondheidszorg } & 35 \\ \text { gedrag en maatschappij } & 35 \\ \text { Totaal } & 38\end{array}$

41,2

$39,3 \quad 39,6$

$38,4 \quad 38,2$

$35,8 \quad 33,7$

33,5

$\begin{array}{ll}38,2 & 37,7\end{array}$

HBO

landbouw

onderwijs

techniek

$39,9 \quad 41,8$

$35,0 \quad 34,9$

$38,9 \quad 40,4$

economie

$38,2 \quad 39,7$

gezondheidszorg

$\begin{array}{ll}38,2 & 39,7 \\ 35,2 & 35,0\end{array}$

gedrag en maatschappij $\quad 34,3 \quad 34,6$

kunst en cultuur $\quad 32,3 \quad 37,1$

$\begin{array}{lll}\text { Totaal } & 37,1 & 38,4\end{array}$

$\begin{array}{llr}\text { Totaal } & 37,4 & 36,8\end{array}$

Toelichting

De gewenste wekelijkse arbeidsduur is bepaald op basis van de vraag in de enquête: Als u zelf zou mogen kiezen, hoeveel uren per week zou u dan het liefst betaald werk willen hebben? (besef hoe minder u werkt, hoe minder $u$ verdient).

De feitelijke wekelijkse arbeidsduur betreft zowel het aantal uren in de hoofdfunctie als het aantal uren in eventuele nevenfuncties. 
Tabel A3.12

Oordeel van de werkende schoolverlaters over de aansluiting tussen de afgesloten opleiding en de huidige functie

\begin{tabular}{|c|c|c|c|c|}
\hline Opleidingssector & $\underset{\%}{\text { goed }}$ & $\begin{array}{c}\text { voldoende } \\
\%\end{array}$ & $\underset{\%}{\operatorname{matig}}$ & $\begin{array}{c}\text { slecht } \\
\%\end{array}$ \\
\hline
\end{tabular}

\section{MBO-kort}

$\begin{array}{lllll}\text { oriënteren en schakelen } & 13 & 49 & 18 & 20 \\ \text { landbouw } & 31 & 30 & 10 & 30 \\ \text { techniek } & 26 & 42 & 18 & 14 \\ \text { economie } & 24 & 41 & 20 & 16 \\ \text { gezondheidszorg } & 33 & 44 & 12 & 11 \\ \text { Totaal } & 23 & 42 & 18 & 16\end{array}$

MBO-tussen en -lang

$\begin{array}{ll}\text { landbouw } & 39 \\ \text { techniek } & 29 \\ \text { economie } & 35 \\ \text { gezondheidszorg } & 4 \\ \text { gedrag en maatschappij } & 34 \\ \text { Totaal } & 34\end{array}$

$\begin{array}{rrrr}39 & 33 & 16 & 13 \\ 29 & 44 & 19 & 8 \\ 35 & 42 & 15 & 8 \\ 41 & 37 & 13 & 8 \\ 34 & 43 & 13 & 10 \\ 34 & 41 & 16 & 9\end{array}$

HBO

\begin{tabular}{lllll} 
landbouw & 35 & 43 & 15 & 8 \\
onderwijs & 27 & 48 & 17 & 8 \\
techniek & 35 & 47 & 14 & 4 \\
economie & 39 & 45 & 12 & 4 \\
gezondheidszorg & 34 & 44 & 18 & 4 \\
gedrag en maatschappij & 33 & 43 & 18 & 6 \\
kunst en cultuur & 29 & 31 & 24 & 15 \\
Totaal & 34 & 45 & 15 & 8 \\
Totaal & 33 & 43 & 16 & \\
\hline
\end{tabular}

Toelichting

Vraag in de enquête: Hoe vindt u de aansluiting tussen uw [...] opleiding en uw huidige functie? 
Tabel A3.13

Percentage werkende schoolverlaters dat op zoek is naar een andere baan

Opleidingssector

AVo

MAVO

HAVO

WWO

Totaal

VBO

landbouw

techniek

economie

17

gezondheidszorg

20

Totaal

MBO-kort

oriënteren en schakelen

landbouw

techniek

economie

gezondheidszorg

Totaal

MBO-tussen en -lang

$\begin{array}{lr}\text { landbouw } & 20 \\ \text { techniek } & 20 \\ \text { economie } & 25 \\ \text { gezondheidszorg } & 25 \\ \text { gedrag en maatschappij } & 32 \\ \text { Totaal } & 24\end{array}$

HBO

landbouw

onderwijs

techniek

economie

gezondheidszorg

gedrag en maatschappij 34

kunst en cultuur

Totaal 26

Totaal 25

Toelichting

Vraag in de enquête: Heeft $u$ in de afgelopen vier weken iets gedaan om aan ander werk te komen? 
Tabel A3.14

Deelname aan een cursus of bedrijfsopleiding door werkende schoolverlaters

Opleidingssector

VBO

landbouw

15

techniek

economie

gezondheidszorg

Totaal

11

19

MBO-kort

oriënteren en schakelen

landbouw

techniek

economie

gezondheidszorg

Totaal

15

18

22

22

11
20

MBO-tussen en -lang

landbouw

techniek

economie

gezondheidszorg

gedrag en maatschappij

Totaal

25

32

41

20

17

HBO

landbouw

onderwijs

techniek

economie

gezondheidszorg

gedrag en maatschappij

kunst en cultuur

Totaal

Totaal

Toelichting

Vraag in de enquête: Heeft u na het verlaten van de [...] opleiding een cursus of bedrijfsopleiding gevolgd? 
Tabel A3.15

Belangrijkste cursussen of bedrijfsopleidingen waaraan werkende schoolverlaters deelnemen

\section{VBO landbouw}

Techniek
Horeca
Landbouw
Veeteelt
Bouwkunde
Grafische techniek
Weg-, railvervoer
Secretarieel (incl. tekstverwerking, steno)
Bedrijfsadministratie, accountancy
Persoonlijke ontplooiing

17

17

8

8

8

8
8

\section{VBO techniek}

Weg-, railvervoer

Economie

Telecommunicatie/datacommunicatie

Computer en informatica

Horeca

Politie

\section{VBO economie}

Marketing, reclame

Communicatieve vaardigheden

$\mathrm{BB}$, bedrijfszelfbescherming

Landmacht

Techniek

Bedrijfsadministratie, accountancy

Commercieel

20

\section{VBO gezondheidszorg}

Uiterlijke verzorging

Ziekenverzorging

Techniek

\section{MBO-kort oriënteren en schakelen}

Administratief

Recht en openbare orde

Secretarieel (incl. tekstverwerking, steno)

Uiterlijke verzorging

\section{MBO-kort landbouw}

Techniek

Bedrijfskunde, management, efficiency

Weg-, railvervoer

Landbouw

Secretarieel (incl. tekstverwerking, steno)

\section{MBO-kort techniek}

Techniek

Elektrotechniek

Weg-, railvervoer

Secretarieel (incl. tekstverwerking, steno)

Metaalbewerking 
Tabel A3.15 (vervolg)

Belangrijkste cursussen of bedrijfsopleidingen waaraan werkende schoolverlaters deelnemen

\section{MBO-kort economie}

Detailhandel (incl. middenstanddiploma)

Secretarieel (incl. tekstverwerking, steno)

Bedrijfsadministratie, accountancy

Commercieel

Administratief

Verzekeringswezen

Techniek

Bedrijfskunde, management, efficiency

Toerisme

MB-kort gezondheidszorg

Administratief

Horeca

Commercieel

Verpleging

Gezondheidszorg

Techniek

Bedrijfskunde, management, efficiency

Zeemacht

\section{MBO-tussen en -lang landbouw}

Veeteelt

Landbouw

Weg-, railvervoer

Tuinbouw

Computer en informatica

Bedrijfskunde, management, efficiency

Techniek

\section{MBO-tussen en -lang techniek}

Techniek

Computer en informatica

Elektrotechniek

Bedrijfstechniek, technische bedrijfsvoering

Bedrijfskunde, management, efficiency

Bouwkunde

MBO-tussen en -lang economie

Marketing, reclame

Bedrijfsadministratie, accountancy

Commercieel

Bedrijfskunde, management, efficiency

Toerisme

Computer en informatica

Verzekeringswezen

Secretarieel (incl. tekstverwerking, steno)

5

MBO-tussen en -lang gezondheidszorg

Verpleging
Farmacie
Commercieel
Uiterlijke verzorging
Gezondheidszorg
Medisch secretarieel
Detailhandel (incl. middenstanddiploma)
Secretarieel (incl. tekstverwerking, steno)


Tabel A3.15 (vervolg)

Belangrijkste cursussen of bedrijfsopleidingen waaraan werkende schoolverlaters deelnemen

$\%$

MBO-tussen en -lang gedrag en maatschappij

Maatschappelijk werk

Computer en informatica

Verpleging

Secretarieel (incl. tekstverwerking, steno)

Personeelswerk

Communicatieve vaardigheden

12

9

6

5

\section{HBO landbouw}

\section{Commercieel}

Computer en informatica

Bedrijfsadministratie, accountancy

Bedrijfskunde, management, efficiency

Veeteelt

Geld- en bankzaken

12

9

7

6

5

HBO onderwijs

Basisonderwijs/onderwijzers (incl. remedial teacher)

28

Pedagog.-didactische Cursus/bedrijfsopl.sen voor leerkrachte

Computer en informatica

Bedrijfskunde, management, efficiency

Verpleging

5

HBO techniek

Computer en informatica

Techniek

Bedrijfskunde, management, efficiency

Commercieel

Bedrijfstechniek, technische bedrijfsvoering

\section{HBO economie}

Computer en informatica

Geld-en bankzaken

Commercieel

Bedrijfsadministratie, accountancy

Verzekeringswezen

Bedrijfskunde, management, efficiency

Marketing, reclame

\section{HBO gezondheidszorg}

Fysiotherapie, bewegingsleer

Verpleging

Logo-/akoepedie, orthopedie

Gezondheidszorg

HBO gedrag en maatschappij

Maatschappelijk werk

Personeelswerk

Computer en informatica

Commercieel

Bedrijfskunde, management, efficiency

Communicatieve vaardigheden 
Tabel A3.15 (vervolg)

Belangrijkste cursussen of bedrijfsopleidingen waaraan werkende schoolverlaters deelnemen

HBO kunst en cultuur

Muziek

Computer en informatica

16

Bedrijfskunde, management, efficiency

Administratief

Communicatieve vaardigheden

14

14

5 
B. Tabellen per opleidingsrichting 
$\ldots$ 
Tabel B1.1

De uitstroom van schoolverlaters verbijzonderd naar geslacht, etniciteit en gemiddelde leeftijd

\begin{tabular}{lccc}
\hline Opleidingsrichting & vrouw & $\begin{array}{c}\text { alloch- } \\
\text { toon } \\
\%\end{array}$ & gem. \\
& $\%$ & leeftijd \\
\hline
\end{tabular}

\section{VBO}

Landbouw en natuurlijke omgeving

Bouwtechniek

Consumptieve techniek

Handel

Verzorging

47
2
25
61
92

MBO-kort

Oriënteren en schakelen $\quad 70$

Plantenteelt (en handel) 20

Veehouderij 38

Dierenverzorging en veterinaire ondersteuning 81

Groene ruimte

Werktuigbouwkunde

Motorvoertuigen en carrosserietechniek

Elektrotechniek

Administratie

Handel

Horeca

Verzorging

Civiele en consumptief technische diensten

\section{MBO-tussen en -lang}

Plantenteelt (en handel)

Veehouderij

Levensmiddelentechnologie

Bloemschikken

$11 \quad 18,3$

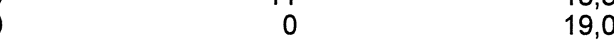

$0 \quad 19,5$

18,8

19,4

20,1

19,4

20,0

19,4

19,0

19,4

19,3

19,5

Dierenverzorging en veterinaire ondersteuning 84

Groene ruimte

Bouwkunde

Werktuigbouwkunde

Elektrotechniek

Technische informatica

Installatietechniek

Houtbewerking en woninginrichting

Weg-en waterbouwkunde

Grafische techniek

Administratie

Handel

Horeca

Toerisme en recreatie

Verpleging

Verzorging

Activiteitenbegeleiding 90

Civiele en consumptief technische diensten 57

Uiterlijke verzorging

Mode en kleding

Sociaal-juridische dienstverlening (AW/SA)

Sociaal-cultureel werker (AW/CW)

Sociaal-pedagogisch werker (AW/SW)

\begin{tabular}{|c|c|c|}
\hline 14 & 0 & 20,1 \\
\hline 24 & 0 & 20,2 \\
\hline 44 & 0 & 20,9 \\
\hline 92 & 1 & 20,0 \\
\hline 84 & 0 & 20,8 \\
\hline 7 & 3 & 21,3 \\
\hline 10 & 2 & 20,8 \\
\hline 2 & 1 & 21,1 \\
\hline 1 & 1 & 19,9 \\
\hline 3 & 3 & 21,0 \\
\hline 1 & 3 & 21,6 \\
\hline 0 & 0 & 20,3 \\
\hline 41 & 2 & 22,8 \\
\hline 5 & 0 & 20,9 \\
\hline 51 & 1 & 21,4 \\
\hline 40 & 3 & 21,4 \\
\hline 53 & 4 & 20,2 \\
\hline 36 & 3 & 20,5 \\
\hline 54 & 1 & 22,1 \\
\hline 89 & 1 & 21,2 \\
\hline 89 & 1 & 20,0 \\
\hline 98 & 3 & 20,1 \\
\hline 99 & 6 & 20,3 \\
\hline 90 & 0 & 22,1 \\
\hline 57 & 4 & 20,7 \\
\hline 99 & 2 & 20,5 \\
\hline 96 & 4 & 20,2 \\
\hline 75 & 10 & 21,3 \\
\hline 93 & 5 & 20,6 \\
\hline & 1 & \\
\hline
\end{tabular}

Zie ook toelichting bladzijde 3 
Tabel B1.2

Vooropleiding van schoolverlaters

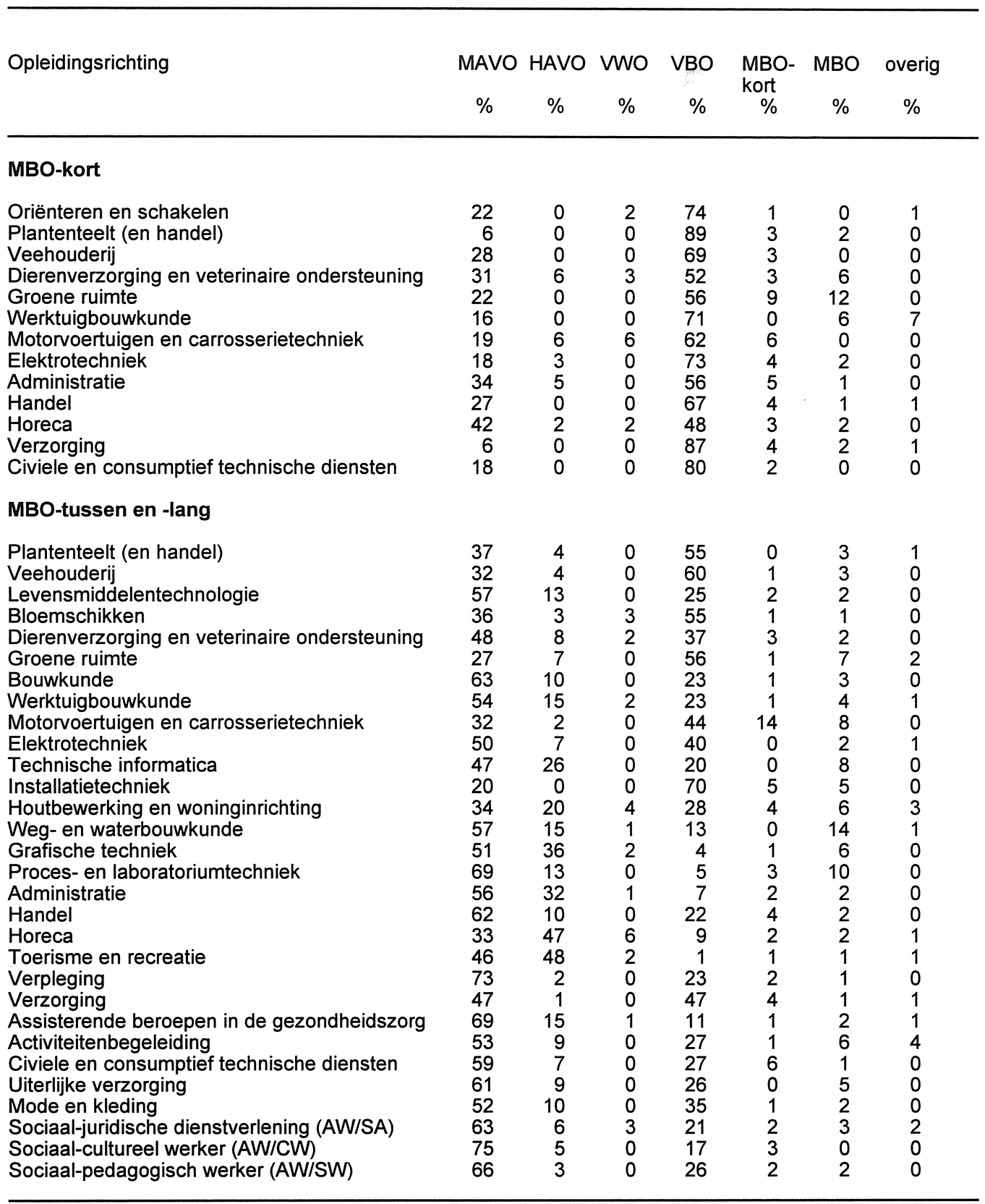


Tabel B1.3

Bestemming van schoolverlaters

\begin{tabular}{lcccccc}
\hline Opleidingsrichting & studie & $\begin{array}{c}\text { LLW/ } \\
\text { in-serv } \\
\%\end{array}$ & $\begin{array}{c}\text { betaald } \\
\text { werk } \\
\%\end{array}$ & $\begin{array}{c}\text { werkloos } \\
\%\end{array}$ & $\begin{array}{c}\text { anders } \\
\%\end{array}$ & \\
\hline
\end{tabular}

VBO

Landbouw en natuurlijke omgeving

Bouwtechniek

Consumptieve techniek

Handel

Verzorging

$\begin{array}{rrrrr}67 & 12 & 18 & 1 & 2 \\ 34 & 23 & 39 & 2 & 2 \\ 39 & 31 & 19 & 10 & 2 \\ 58 & 2 & 30 & 8 & 2 \\ 64 & 11 & 18 & 2 & 5\end{array}$

MBO-kort

Oriënteren en schakelen

Plantenteelt (en handel)

Veehouderij

Dierenverzorging en veterinaire ondersteuning 28

Groene ruimte

Werktuigbouwkunde

Motorvoertuigen en carrosserietechniek

Elektrotechniek

Administratie

Handel

Horeca

Verzorging

Civiele en consumptief technische diensten

$\begin{array}{rrrrr}57 & 8 & 24 & 8 & 3 \\ 6 & 9 & 72 & 10 & 2 \\ 0 & 7 & 87 & 7 & 0 \\ 28 & 3 & 69 & 0 & 0 \\ 21 & 24 & 55 & 0 & 0 \\ 13 & 10 & 62 & 14 & 1 \\ 18 & 6 & 76 & 0 & 0 \\ 14 & 15 & 57 & 6 & 8 \\ 28 & 7 & 54 & 7 & 4 \\ 28 & 8 & 52 & 7 & 4 \\ 19 & 35 & 41 & 2 & 2 \\ 36 & 16 & 40 & 5 & 4 \\ 15 & 35 & 27 & 13 & 10\end{array}$

\section{MBO-tussen en -lang}

Plantenteelt (en handel)

Veehouderij

Levensmiddelentechnologie

Bloemschikken

Dierenverzorging en veterinaire ondersteuning 20

Groene ruimte

Bouwkunde

Werktuigbouwkunde

Motorvoertuigen en carrosserietechniek

Elektrotechniek

Technische informatica

Installatietechniek

Houtbewerking en woninginrichting

Weg- en waterbouwkunde

Grafische techniek

Proces- en laboratoriumtechniek

Administratie

Handel

Horeca

Toerisme en recreatie

Verpleging

Verzorging

Assisterende beroepen in de gezondheidszorg

Activiteitenbegeleiding

Civiele en consumptief technische diensten

Uiterlijke verzorging

Mode en kleding

Sociaal-juridische dienstverlening (AW/SA)

Sociaal-cultureel werker (AW/CW)

Sociaal-pedagogisch werker (AW/SW)

$\begin{array}{rrrrr}20 & 4 & 67 & 7 & 1 \\ 18 & 4 & 71 & 4 & 2 \\ 41 & 2 & 52 & 4 & 0 \\ 12 & 0 & 82 & 5 & 1 \\ 20 & 0 & 72 & 7 & 2 \\ 26 & 2 & 67 & 5 & 1 \\ 41 & 1 & 56 & 2 & 0 \\ 34 & 2 & 61 & 0 & 3 \\ 5 & 24 & 52 & 14 & 5 \\ 42 & 3 & 52 & 2 & 1 \\ 37 & 0 & 62 & 0 & 1 \\ 5 & 15 & 75 & 0 & 5 \\ 15 & 2 & 74 & 5 & 4 \\ 45 & 0 & 52 & 2 & 1 \\ 21 & 0 & 73 & 5 & 1 \\ 39 & 1 & 55 & 4 & 0 \\ 35 & 1 & 58 & 4 & 1 \\ 30 & 2 & 61 & 6 & 2 \\ 26 & 0 & 70 & 3 & 1 \\ 17 & 1 & 79 & 4 & 0 \\ 39 & 17 & 41 & 2 & 1 \\ 13 & 21 & 63 & 2 & 1 \\ 12 & 2 & 80 & 5 & 1 \\ 20 & 4 & 68 & 7 & 1 \\ 21 & 3 & 67 & 4 & 5 \\ 4 & 2 & 81 & 10 & 3 \\ 32 & 2 & 59 & 7 & 1 \\ 45 & 0 & 45 & 6 & 4 \\ 47 & 6 & 41 & 3 & 2 \\ 32 & 9 & 53 & 6 & 0\end{array}$

Zie ook toelichting bladzijde 5 


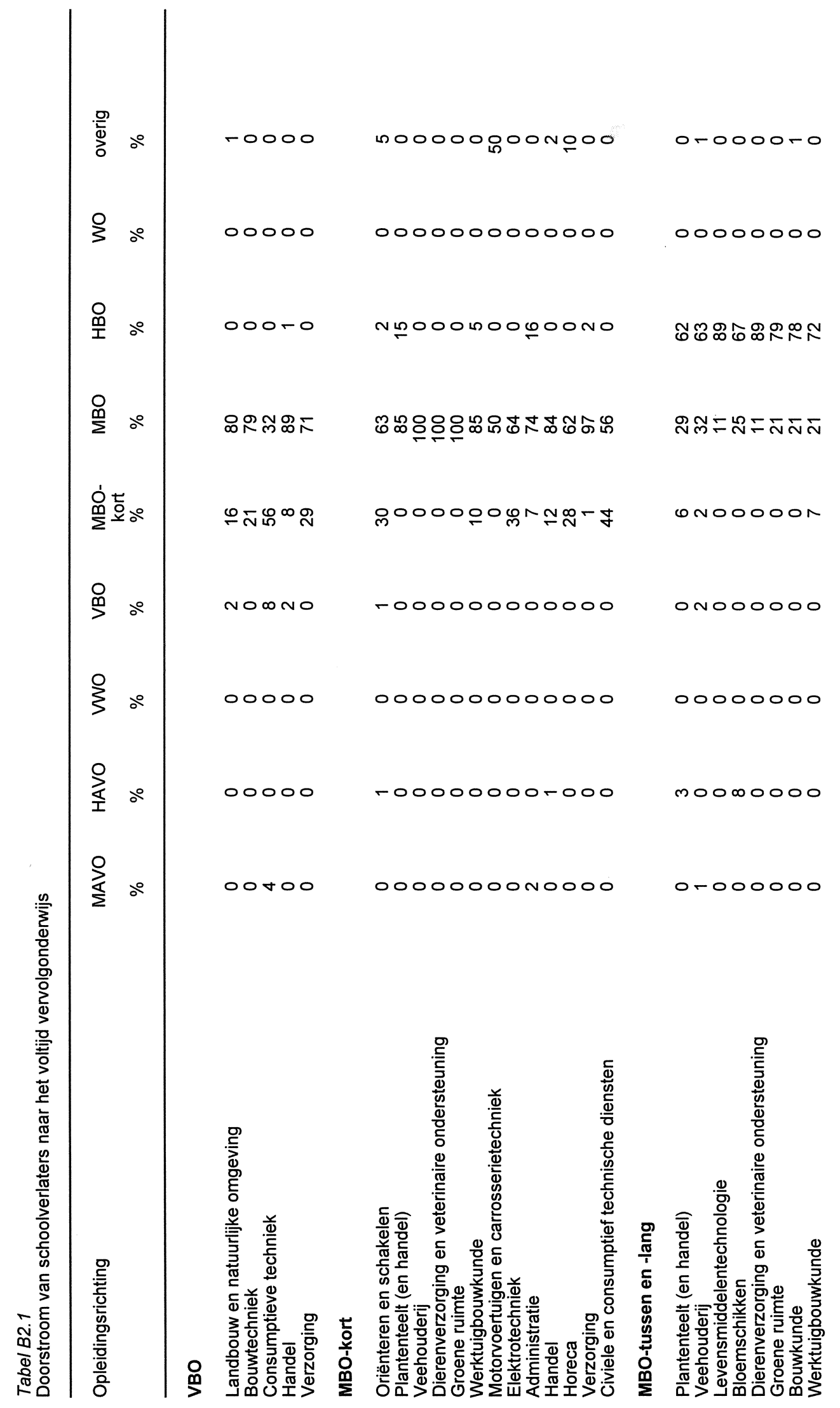




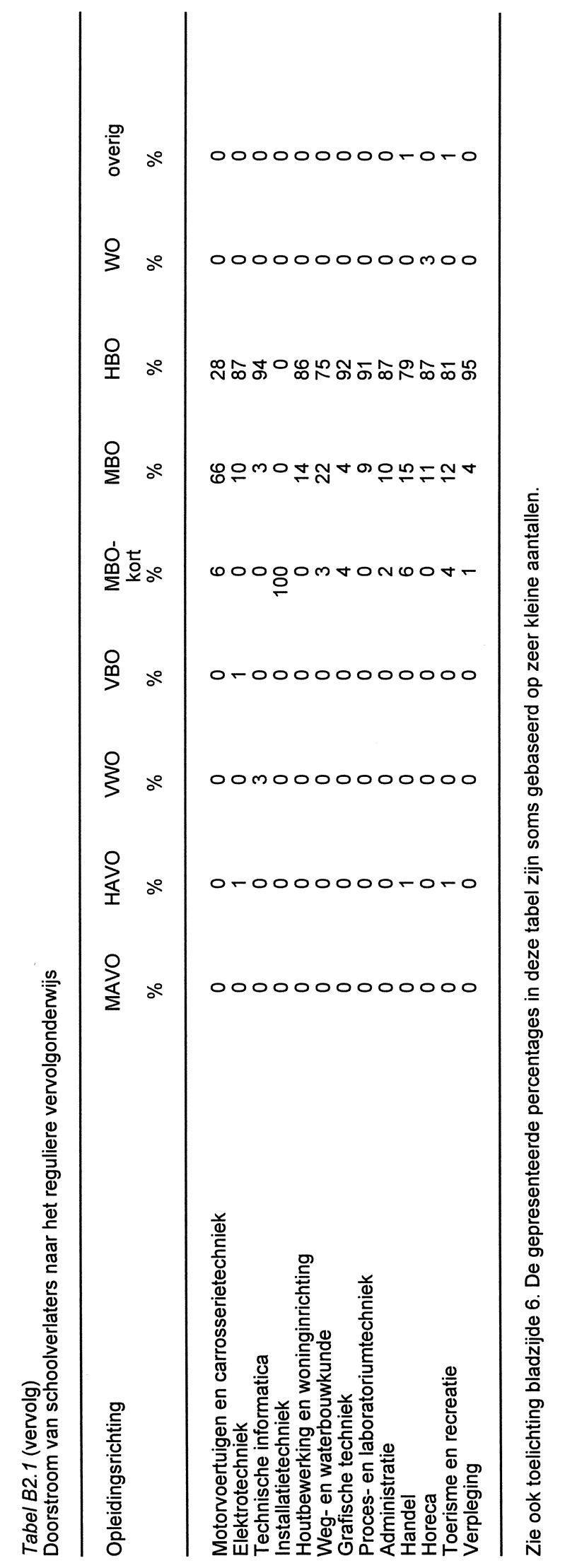


Tabel B2.2

Belangrijkste opleidingen van schoolverlaters die een voltijd vervolgopleiding zijn gaan volgen

VBO Landbouw en natuurlijke omgeving

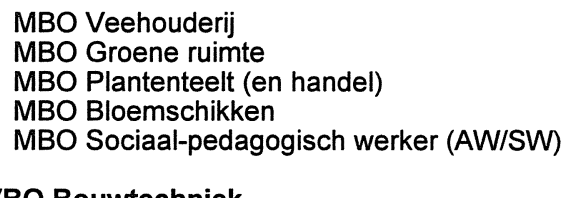

\section{VBO Bouwtechniek}

MBO Bouwkunde

MBO Houtbewerking en woninginrichting

MBO Kort Houtbewerking en woninginrichting

VBO Consumptieve techniek

MBO Kort Brood- en banketbakken

MBO Kort Horeca

MBO Horeca

VBO Consumptieve techniek

MBO Horeca

VBO Handel

MBO Handel

MBO Administratie

MBO Sociaal-pedagogisch werker (AW/SW)

MBO Mode en kleding

MBO Economie

\section{VBO Verzorging}

MBO Sociaal-pedagogisch werker (AW/SW)

MBO Verzorging

MBO Kort Verzorging

MBO Uiterlijke verzorging

MBO Kort Oriënteren en schakelen

MBO Assisterende beroepen in de gezondheidszorg

MBO Verpleging

MBO Kort Oriënteren en schakelen orienteren en schakelen

MBO Sociaal-pedagogisch werker (AW/SW)

MBO Verzorging

MBO Kort Handel

MBO Kort Administratie

MBO Uiterlijke verzorging

MBO Kort Plantenteelt (en handel)

MBO Landbouw

MBO Veehouderij

MBO Administratie

HBO Leraar VO maatschappij 1-vak (2e gr.)

MBO Kort Veehouderij

MBO Plantenteelt (en handel)

MBO Handel

MBO Sociaal-pedagogisch werker (AW/SW) 
Tabel B2.2 (vervolg)

Belangrijkste opleidingen van schoolverlaters die een voltijd vervolgopleiding zijn gaan volgen

$\%$

MBO Kort Dierenverzorging en veterinaire ondersteuning

MBO Dierenverzorging en veterinaire ondersteuning 67

MBO Milieutoezicht 22

MBO Dierenverzorging en veterinaire ondersteuning 11

MBO Kort Groene ruimte

MBO Grafische techniek

MBO Groene ruimte

MBO Kort Werktuigbouwkunde

MBO Elektrotechniek

MBO Werktuigbouwkunde

MBO Kort Elektrotechniek

MBO

MBO Nautische opleidingen

HBO Opleiding tot verpleegkundige

MBO Kort Motorvoertuigen en carrosserietechniek

VHBO

MBO Bedrijfsmanagement motorvoertuigen

MBO Kort Elektrotechniek

$\begin{array}{lr}\text { MBO Elektrotechniek } & 40 \\ \text { MBO Kort Installatietechniek } & 24 \\ \text { MBO Kort Mode en kleding } & 11 \\ \text { MBO Horeca } & 11 \\ \text { MBO Motorvoertuigen en carrosserietechniek } & 7 \\ \text { MBO Politie } & 7\end{array}$

MBO Kort Administratie

MBO Administratie

HBO Commerciele economie

HBO Facilitaire dienstverlening

MBO Toerisme en recreatie

57

MBO Kort Handel

MBO Handel

MBO Textielhandel

MBO Administratie

MBO Mode en kleding

MBO Kort Horeca

MBO Horeca

MBO Kort Civiele en consumptief technische diensten

VHBO

MBO Kort Techniek

MBO Handel

MBO Levensmiddelenhandel

MBO Kort Verzorging

MBO Economie

MBO Sociaal-juridische dienstverlening (AW/SA) 
Tabel B2.2 (vervolg)

Belangrijkste opleidingen van schoolverlaters die een voltijd vervolgopleiding zijn gaan volgen

$\%$

$\begin{array}{lr}\text { MBO Kort Verzorging } & \\ \text { MBO Verzorging } & 64 \\ \text { MBO Sociaal-pedagogisch werker (AW/SW) } & 23 \\ \text { MBO Verpleging } & 7\end{array}$

MBO Kort Civiele en consumptief technische diensten

MBO Civiele en consumptief technische diensten

MBO Kort Civiele en consumptief technische diensten 22

MBO Kort Brood- en banketbakken 17

7

MBO Kort Verzorging

MBO Handel

\section{MBO Plantenteelt (en handel)}

HBO Tuinbouw

HBO Plantenteelt

HBO Agrarische bedrijfskunde

MBO Plantenteelt (en handel)

HBO Landbouw

MBO Veehouderij

HBO Veehouderij

23

HBO Agrarische bedrijfskunde

HBO Landbouw

MBO Veehouderij

MBO Veehouderij

MBO Handel

MBO Levensmiddelentechnologie

HBO Levensmiddelentechnologie

HBO Voeding en marketing 16

HBO Voeding en dietetiek 13

MBO Bloemschikken

HBO Biotechnologie $\quad 17$

HBO Docent plantenteelt en verwerking

HBO Sociaal-pedagogische hulpverlening 17

MBO Plantenteelt (en handel)

MBO Bloemschikken $\quad 9$

MBO Vliegtuigtechniek $\quad 8$

$\begin{array}{lr}\text { HBO Internationale agrarische handel } & 8 \\ \text { HBO Leraar basis-/speciaalonderwijs } & 8\end{array}$

MBO Dierenverzorging en veterinaire ondersteuning

HBO Leraar VO exact 1-vak (2e gr.)

HBO Veehouderij 11

HBO Diermanagement 11

HBO Docent veehouderij en verwerking 11

MBO Levensmiddelentechnologie $\quad 6$

MBO Levensmiddelentechnologie 6

$\begin{array}{ll}\text { HBO Initieel } & 6 \\ \text { HBO Analytische proces- en laboratoriuminstrumentatie } & 6\end{array}$ 
Tabel B2.2 (vervolg)

Belangrijkste opleidingen van schoolverlaters die een voltijd vervolgopleiding zijn gaan volgen

\section{MBO Groene ruimte}

HBO Tuin- en landschapsinrichting

HBO Land, water en milieubeheer

MBO Groene ruimte

HBO Bos- en natuurbeheer

HBO Docent plantenteelt en verwerking

MBO Administratie

\section{MBO Bouwkunde}

HBO Bouwkunde

MBO Weg-en waterbouwkunde

MBO Administratie

MBO Werktuigbouwkunde

HBO Werktuigbouwkunde

MBO Motorvoertuigen en carrosserietechniek

MBO Motorvoertuigen en carrosserietechniek

MBO Bedrijfsmanagement motorvoertuigen

HBO Autotechniek

MBO Motorvoertuigen en carrosserietechniek

MBO Elektrotechniek

\section{MBO Elektrotechniek}

HBO Elektrotechniek

HBO Technische bedrijfskunde

HBO Computertechniek

HBO Hogere informatica

MBO Technische informatica

HBO Hogere informatica

HBO Elektrotechniek

HBO Informatica en informatiekunde

HBO Kort Techniek

MBO Installatietechniek

MBO Kort Oriënteren en schakelen

MBO Houtbewerking en woninginrichting

HBO Architectonische vormgeving

HBO Bouwkunde

HBO Leraar VO expressie 1-vak (2e gr.)

HBO Sociaal-pedagogische hulpverlening

HBO Kunst en cultuur

MBO Techniek

MBO Activiteitenbegeleiding

MBO Sociaal-juridische dienstverlening (AW/SA)

HBO Opleiding voor management, economie en recht

HBO Commerciele economie

HBO Communicatie

HBO Algemene industriele vormgeving

HBO Museologie 
Tabel B2.2 (vervolg)

Belangrijkste opleidingen van schoolverlaters die een voltijd vervolgopleiding zijn gaan volgen

MBO Weg- en waterbouwkunde

HBO Civiele techniek

MBO Weg- en waterbouwkunde

HBO Geodesie

MBO Grafische techniek

HBO Publiciteits- c.q. grafische vormgeving

HBO Technische bedrijfskunde

HBO Leraar VO expressie 1-vak (2e gr.)

20

12

8

MBO Proces- en laboratoriumtechniek

HBO Chemische technologie

HBO Chemische laboratoriumopleiding

HBO Milieukunde

HBO Analytische proces- en laboratoriuminstrumentatie

HBO Medische laboratoriumopleiding

HBO Biologische laboratoriumopleiding

MBO Administratie

HBO Commerciele economie

HBO Bedrijfseconomie (ook OU)

HBO Opleiding voor management, economie en recht

MBO Administratie

HBO Accountancy

HBO Logistiek en economie

\section{MBO Handel}

HBO Commerciele economie

HBO Small business

HBO Opleiding voor management, economie en recht

HBO Facilitaire dienstverlening

\section{MBO Horeca}

HBO Hoger hotelonderwijs

HBO Facilitaire dienstverlening

MBO Administratie

HBO Communicatie

HBO Publiciteits- c.q. grafische vormgeving

HBO Kort Techniek

HBO Bedrijfseconomie (ook OU)

HBO Commerciele economie

\section{MBO Toerisme en recreatie}

HBO Kort Toeristisch en recreatief onderwijs HBO Facilitaire dienstverlening

HBO Culturele en maatschappelijke vorming

HBO Communicatie

HBO Hoger toeristisch en recreatief onderwijs

HBO Journalistiek en voorlichting

HBO Kort Techniek

MBO Verpleging

HBO Opleiding tot verpleegkundige 
Tabel B2.2 (vervolg)

Belangrijkste opleidingen van schoolverlaters die een voltijd vervolgopleiding zijn gaan volgen

\section{MBO Verzorging}

HBO Opleiding tot verpleegkundige

MBO Verpleging

MBO Verzorging

MBO Assisterende beroepen in de gezondheidszorg

MBO Assisterende beroepen en de gezondheidszorg

HBO Opleiding tot verpleegkundige

MBO Assisterende beroepen in de gezondheidszorg

HBO Mondhygiënist

HAVO

HBO Voeding en dietetiek

HBO Maatschappelijk werk en dienstverlening

MBO Activiteitenbegeleiding

$$
\begin{aligned}
& \text { HBO Sociaal-pedagogische hulpverlening } \\
& \text { HBO Culturele en maatschappelijke vorming } \\
& \text { HBO Maatschappelijk werk en dienstverlening } \\
& \text { HBO Leraar basis-/speciaalonderwijs } \\
& \text { HBO Leraar VO expressie 1-vak (2e gr.) } \\
& \text { HBO Opleiding voor ergotherapie }
\end{aligned}
$$

MBO Civele en consuptief technische diensten

HBO Facilitaire dienstverlening

HBO

HBO Leraar basis-/speciaalonderwijs

MBO Horeca

MBO Toerisme en recreatie

MBO Uiterlijke verzorging

HBO Communicatie

MBO Uiterlijke verzorging

HAVO

MBO Kort Administratie

MBO Administratie

MBO Uiterlijke verzorging

HBO Leraar basis-/speciaalonderwijs

MBO Mode en Kleding

HBO Beeldende Kunst en Vormgeving - vrij HBO Modevormgeving

HBO Leraar VO expressie 1-vak (2e gr.)

HBO Kunst en cultuur

HBO Textiele vormgeving

MBO Sociaal-juridische dienstverlening (AWISA)

HBO Personeel en arbeid

HBO Maatschappelijk werk en dienstverlening

HBO Sociaal-juridische dienstverlening

HBO Sociaal-pedagogische hulpverlening

MBO Sociaal-cultureel werker (AW/CW)

HBO Sociaal-pedagogische hulpverlening HBO Leraar basis-/speciaalonderwijs 
Tabel B2.2 (vervolg)

Belangrijkste opleidingen van schoolverlaters die een voltijd vervolgopleiding zijn gaan volgen

$\%$

MBO Sociaal-pedagogisch werker (AWISW)

HBO Sociaal-pedagogische hulpverlening

HBO Leraar basis-/speciaalonderwijs

34

HBO Maatschappelijk werk en dienstverlening

HBO Opleiding tot verpleegkundige

De gepresenteerde percentages in deze tabel zijn soms gebaseerd op zeer kleine aantallen. 
Tabel B2.3

Oordeel van schoolverlaters over de aansluiting van de afgesloten opleiding met de voltijd vervolgopleiding en het percentage schoolverlaters dat deze vervolgopleiding achteraf bezien opnieuw zou kiezen

\begin{tabular}{cccccc}
\hline & \multicolumn{3}{c}{ oordeel } & & \\
Opleidingsrichting & goed & $\begin{array}{c}\text { vol- } \\
\text { doende }\end{array}$ & matig & slecht & $\begin{array}{c}\text { opnieuw } \\
\text { kiezen } \\
\%\end{array}$ \\
\hline
\end{tabular}

VBO

Landbouw en natuurlijke omgeving

Bouwtechniek

Consumptieve techniek

Handel

Verzorging

$\begin{array}{llr}35 & 40 & 18 \\ 46 & 29 & 17 \\ 50 & 42 & 8 \\ 41 & 29 & 16 \\ 39 & 41 & 12\end{array}$

$\begin{array}{rr}6 & x \\ 8 & 90 \\ 0 & 82 \\ 14 & 80 \\ 8 & 71\end{array}$

MBO-kort

Oriënteren en schakelen

Plantenteelt (en handel)

Veehouderij

Dierenverzorging en veterinaire

ondersteuning

Groene ruimte

Werktuigbouwkunde

Motorvoertuigen en carrosserietechniek

Elektrotechniek

Administratie

Handel

Horeca

Verzorging

Civiele en consumptief technische

diensten

$\begin{array}{rrrrr}46 & 39 & 14 & 2 & \mathrm{x} \\ 0 & 35 & 35 & 30 & \mathrm{x} \\ 67 & 0 & 0 & 33 & \mathrm{x} \\ & & & & \mathrm{x} \\ 11 & 22 & 56 & 11 & \mathrm{x} \\ 66 & 0 & 34 & 0 & \mathrm{x} \\ 55 & 25 & 20 & 0 & \mathrm{x} \\ 0 & 0 & 50 & 50 & \mathrm{x} \\ 46 & 22 & 32 & 0 & \mathrm{x} \\ 35 & 32 & 17 & 16 & \mathrm{x} \\ 50 & 33 & 14 & 3 & \mathrm{x} \\ 4 & 69 & 8 & 18 & \\ 53 & 25 & 17 & 6 & \\ & & & & \\ 49 & 39 & 0 & 12 & \end{array}$

MBO-tussen en -lang

Plantenteelt (en handel)

Veehouderij

Levensmiddelentechnologie

Bloemschikken

Dierenverzorging en veterinaire

ondersteuning

Groene ruimte

Bouwkunde

Werktuigbouwkunde

carrosserietechniek 53

Elektrotechniek

Technische informatica

Installatietechniek

Houtbewerking en woninginrichting

Weg- en waterbouwkunde

Grafische techniek

Proces- en laboratoriumtechniek

Administratie

Handel

Horeca

$\begin{array}{rrrrl}24 & 51 & 12 & 12 & \mathrm{x} \\ 23 & 27 & 37 & 13 & \mathrm{x} \\ 49 & 29 & 12 & 10 & \mathrm{x} \\ 18 & 0 & 45 & 36 & \mathrm{x} \\ & & & & \mathrm{x} \\ 24 & 24 & 29 & 24 & \mathrm{x} \\ 22 & 52 & 19 & 8 & \mathrm{x} \\ 46 & 38 & 12 & 4 & \mathrm{x} \\ 44 & 45 & 8 & 3 & \mathrm{x} \\ 53 & 35 & 3 & 9 & \mathrm{x} \\ 36 & 42 & 16 & 6 & \mathrm{x} \\ 50 & 28 & 19 & 3 & \mathrm{x} \\ 0 & 100 & 0 & 0 & \mathrm{x} \\ 41 & 35 & 18 & 6 & \mathrm{x} \\ 45 & 46 & 6 & 3 & \mathrm{x} \\ 20 & 44 & 20 & 16 & \mathrm{x} \\ 57 & 23 & 18 & 3 & 7 \\ 44 & 34 & 15 & 10 & \\ 28 & 43 & 19 & 10 & 3 \\ 32 & 41 & 25 & 3 & \end{array}$

$\mathrm{x}=$ vraag niet opgenomen

Zie ook toelichting bladzijde 10. De gepresenteerde percentages in deze tabel zijn soms gebaseerd op zeer kleine aantallen. 
Tabel B2.4

Doorstroom van schoolverlaters naar het duale vervolgonderwijs

VBO Landbouw en natuurlijke omgeving

LOBAS
SBW
Transport en logistiek
L-OVD
SOM
OCH
SVB
SVK
OVDB

VBO Bouwtechniek

$\begin{array}{lr}\text { SVB } & 31 \\ \text { SVS } & 31 \\ \text { SH\&M } & 12 \\ \text { INNOVAM } & 6 \\ \text { Transport en logistiek } & 6 \\ \text { LLW rest } & 6 \\ \text { LLW/In-service rest } & 6\end{array}$

VBO Consumptieve techniek

$\mathrm{OCH}$

SOBEB

L-OVD

SVO

SVK

LLW rest

VBO Handel

L-OVD

INNOVAM

$\mathrm{OCH}$

ECABO

SVK

VBO Verzorging

$\mathrm{OCH}$

SVK

L-OVD

In-service Ziekenverzorgende

OVDB

MBO Kort Oriënteren en schakelen

$\mathrm{OCH}$

OVDB

ECABO

L-OVD

SVK

In-service verpleegkundige A

In-service Ziekenverzorgende

LLW/In-service rest

MBO Kort Plantenteelt (en handel)

LOBAS

SBW 
Tabel B2.4 (vervolg)

Doorstroom van schoolverlaters naar het duale vervolgonderwijs

MBO Kort Veehouderij

LOBAS

Transport en logistiek

MBO Kort Dierenverzorging en veterinaire ondersteuning

SVO

MBO Kort Groene ruimte

LOBAS

82

SVB

MBO Kort Werktuigbouwkunde

SOM

INNOVAM

LLW rest

84

10
5

MBO Kort Motorvoertuigen en carrosserietechniek

INNOVAM

SOM

MBO Kort Elektrotechniek

VEV

INTECHNIUM

LLW rest

SOM

L-OVD

MBO Kort Administratie

ECABO

L-OVD

MBO Kort Handel

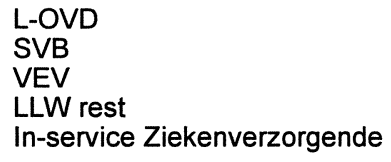

SVB

In-service Ziekenverzorgende

MBO Kort Horeca

$\mathrm{OCH}$

SVB

MBO Kort Verzorging

OVDB

In-service Ziekenverzorgende

MBO Kort Civiele en consumptief technische diensten

$\mathrm{OCH}$

ECABO

SOBEB

In-service Ziekenverzorgende 
MBO Plantenteelt (en handel)

$\begin{array}{lr}\text { LOBAS } & 55 \\ \text { SOM } & 18 \\ \text { SVS } & 9 \\ \text { ECABO } & 9 \\ \text { LLW rest } & 9\end{array}$

MBO Veehouderij

$\begin{array}{lr}\text { LOBAS } & 37 \\ \text { SOM } & 24 \\ \text { SBW } & 15 \\ \text { Transport en logistiek } & 10 \\ \text { SVS } & 5 \\ \text { ECABO } & 5 \\ \text { OVDB } & 3 \\ \text { In-service Ziekenverzorgende } & 3\end{array}$

MBO Levensmiddelentechnologie

VAPRO

In-service Ziekenverzorgende

MBO Bloemschikken

LOBAS

OVDB

MBO Groene ruimte

LOBAS

LLW rest

VOC-car

SBW

MBO Bouwkunde

SVB

ECABO

MBO Werktuigbouwkunde

SOM

INNOVAM

VEV

MBO Motorvoertuigen en carrosserietechniek

$\begin{array}{lr}\text { INNOVAM } & 59 \\ \text { VEV } & 27 \\ \text { Transport en logistiek } & 13 \\ \text { VOC-car } & 1\end{array}$

$$
\text { VOC-car }
$$

MBO Elektrotechniek

VEV

ECABO

SOM

LLW rest 
Tabel B2.4 (vervolg)

Doorstroom van schoolverlaters naar het duale vervolgonderwijs

$\%$

MBO Installatietechniek

VEV

INTECHNIUM

38

LLW rest

25

SBW

MBO Houtbewerking en woninginrichting

In-service Ziekenverzorgende

MBO Proces- en laboratoriumtechniek

ECABO

SVB

INTECHNIUM

SOM

40

MBO Administratie

ECABO

Transport en logistiek

SVB

LLW rest

OVDB

61

MBO Handel

ECABO
L-OVD
LOBAS
SOM
SVO
VEV
VOC/BETEX
OVDB

50

12

LOBAS

VOC/BETEX

OVDB

17

MBO Toerisme en recreatie

In-service Ziekenverzorgende

MBO Verpleging

In-service Z-verpleegkundige

In-service verpleegkundige $A$

In-service verpleegkundige $B$

In-service Ziekenverzorgende

In-service rest

47

36

14

\section{MBO Verzorging}

In-service Ziekenverzorgende

In-service verpleegkundige A

In-service Z-verpleegkundige

OVDB

In-service rest

LOBAS

LLW rest

LLW/In-service rest 
Tabel B2.4 (vervolg)

Doorstroom van schoolverlaters naar het duale vervolgonderwijs

MBO Assisterende beroepen en de gezondheidszorg

In-service verpleegkundige $A$

OVDB

40

In-service Operatie-assistent

SVGB

MBO Activiteitenbegeleiding

In-service Z-verpleegkundige

In-service Ziekenverzorgende

In-service verpleegkundige $B$

In-service verpleegkundige $A$

LOBAS

MBO Civele en consumptief technische diensten

$\mathrm{OCH}$

In-service verpleegkundige $A$

MBO Uiterlijke verzorging

SVK

60

ECABO

20

In-service Ziekenverzorgende

MBO Mode en Kleding

SVS

ECABO

$\mathrm{OCH}$

MBO Sociaal-juridische dienstverlening (AW/SA)

VOC-car

MBO Sociaal-cultureel werker (AW/CW)

In-service Z-verpleegkundige

MBO Sociaal-pedagogisch werker (AWISW)

In-service Z-verpleegkundige

In-service Ziekenverzorgende

In-service verpleegkundige B

In-service verpleegkundige $A$

OVDB

SVGB

L-OVD

SVO

LOBAS

In-service rest

De gepresenteerde percentages in deze tabel zijn soms gebaseerd op zeer kleine aantallen. 
Tabel B2.5

Oordeel van schoolverlaters over de aansluiting van de afgesloten opleiding met de duale vervolgopleiding en het percentage schoolverlaters dat deze duale vervolgopleiding achteraf bezien opnieuw zou kiezen

\begin{tabular}{|c|c|c|c|c|c|}
\hline \multirow[b]{2}{*}{ Opleidingsrichting } & \multicolumn{4}{|c|}{ oordeel } & \multirow[b]{2}{*}{$\begin{array}{c}\text { opnieuw } \\
\text { kiezen } \\
\%\end{array}$} \\
\hline & $\begin{array}{c}\text { goed } \\
\%\end{array}$ & $\begin{array}{c}\text { vol- } \\
\text { doende } \\
\%\end{array}$ & $\begin{array}{c}\text { matig } \\
\%\end{array}$ & $\begin{array}{c}\text { slecht } \\
\%\end{array}$ & \\
\hline
\end{tabular}

VBO

Landbouw en natuurlijke omgeving

Bouwtechniek

Consumptieve techniek

Handel

Verzorging

$\begin{array}{ll}36 & 49 \\ 56 & 31 \\ 52 & 18 \\ 40 & 42 \\ 37 & 32\end{array}$

$\begin{array}{rr}3 & 11 \\ 12 & 0 \\ 15 & 15 \\ 0 & 18 \\ 31 & 0\end{array}$

MBO-kort

Oriënteren en schakelen

Plantenteelt (en handel)

Veehouderij

$\begin{array}{lllll}46 & 38 & 9 & 8 & \mathrm{x}\end{array}$

Dierenverzorging en veterinaire

ondersteuning

Groene ruimte

57

32

9
11
0

0
50

$x$

Werktuigbouwkunde

Motorvoertuigen en carrosserietechniek 57

Elektrotechniek

Administratie

Handel

Horeca

Verzorging

Civiele en consumptief technische

diensten

0
9
28
29
59
43
34
38
46

$0 \quad 100$

$18 \quad 18$

$\begin{array}{rr}10 & 0 \\ 0 & 14\end{array}$

MBO-tussen en -lang

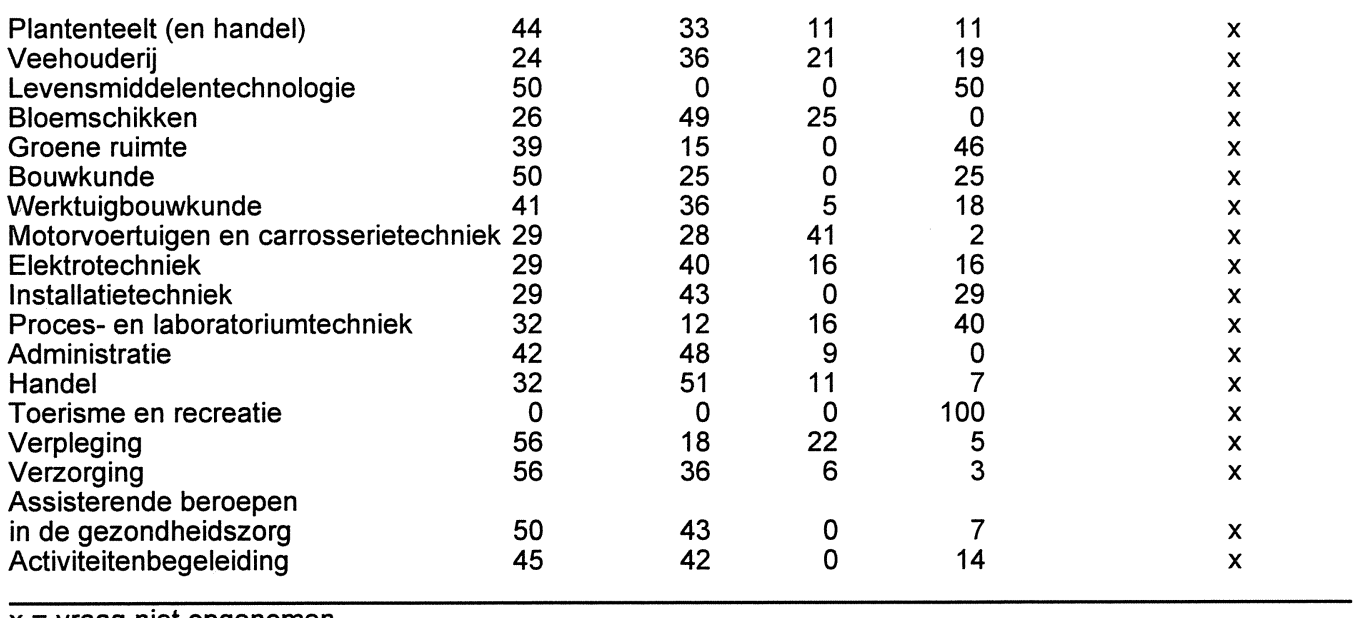

$\mathrm{x}=$ vraag niet opgenomen

Zie ook toelichting bladzijde 16. De gepresenteerde percentages in deze tabellen zijn soms gebaseerd op zeer kleine aantallen. 
Tabel B3.1

Werkloosheid en gemiddelde intredewerkloosheid van schoolverlaters die zich aanbieden op de arbeidsmarkt

\begin{tabular}{lcc}
\hline Opleidingsrichting & $\begin{array}{c}\text { werkloosheid } \\
\%\end{array}$ & $\begin{array}{c}\text { intredewerkloosheid } \\
\text { maanden }\end{array}$
\end{tabular}

VBO

Landbouw en natuurlijke omgeving

Bouwtechniek

Consumptieve techniek

Handel

Verzorging

$\begin{array}{rr}4 & 0,9 \\ 4 & 1,9 \\ 14 & 2,0 \\ 8 & 3,2 \\ 22 & 0,8\end{array}$

MBO-kort

Oriënteren en schakelen

Plantenteelt (en handel)

Veehouderij

Dierenverzorging en veterinaire ondersteuning

Groene ruimte

Werktuigbouwkunde

Motorvoertuigen en carrosserietechniek

Elektrotechniek

Administratie

Handel

Horeca

Verzorging

Civiele en consumptief technische diensten

$\begin{array}{rr}15 & 3,2 \\ 8 & 1,1 \\ 4 & 0,9 \\ 4 & 1,8 \\ 12 & 0,6 \\ 4 & 3,4 \\ 7 & 0,8 \\ 9 & 1,1 \\ 13 & 1,5 \\ 10 & 2,6 \\ 5 & 0,3 \\ 11 & 2,1 \\ 29 & 2,4\end{array}$

\section{MBO-tussen en -lang}

Plantenteelt (en handel)

Veehouderij

Levensmiddelentechnologie

Bloemschikken

Dierenverzorging en veterinaire ondersteuning

Groene ruimte

Bouwkunde

Werktuigbouwkunde

Motorvoertuigen en carrosserietechniek

Elektrotechniek

Technische informatica

Installatietechniek

Houtbewerking en woninginrichting

Weg-en waterbouwkunde

Grafische techniek

Proces- en laboratoriumtechniek

Administratie

Handel

Horeca

Toerisme en recreatie

Verpleging

Verzorging

Assisterende beroepen in de gezondheidszorg

Activiteitenbegeleiding

Civiele en consumptief technische diensten

Uiterlijke verzorging

Mode en kleding

Sociaal-juridische dienstverlening (AW/SA)

Sociaal-cultureel werker (AW/CW)

Sociaal-pedagogisch werker (AW/SW)

\begin{tabular}{rr}
7 & 0,8 \\
2 & 0,4 \\
10 & 0,9 \\
4 & 0,6 \\
6 & 1,5 \\
6 & 1,1 \\
4 & 0,6 \\
2 & 0,3 \\
21 & 3,2 \\
6 & 0,8 \\
2 & 0,4 \\
0 & 0,3 \\
9 & 1,0 \\
1 & 0,4 \\
9 & 0,9 \\
6 & 1,5 \\
6 & 0,9 \\
8 & 1,0 \\
4 & 0,6 \\
5 & 0,9 \\
4 & 0,8 \\
6 & 0,8 \\
7 & 1,0 \\
7 & 1,1 \\
5 & 1,5 \\
13 & 1,7 \\
11 & 1,3 \\
17 & 2,3 \\
6 & 1,4 \\
10 & 1,1 \\
\hline & 1,1
\end{tabular}

Zie ook toelichting bladzijde 17 


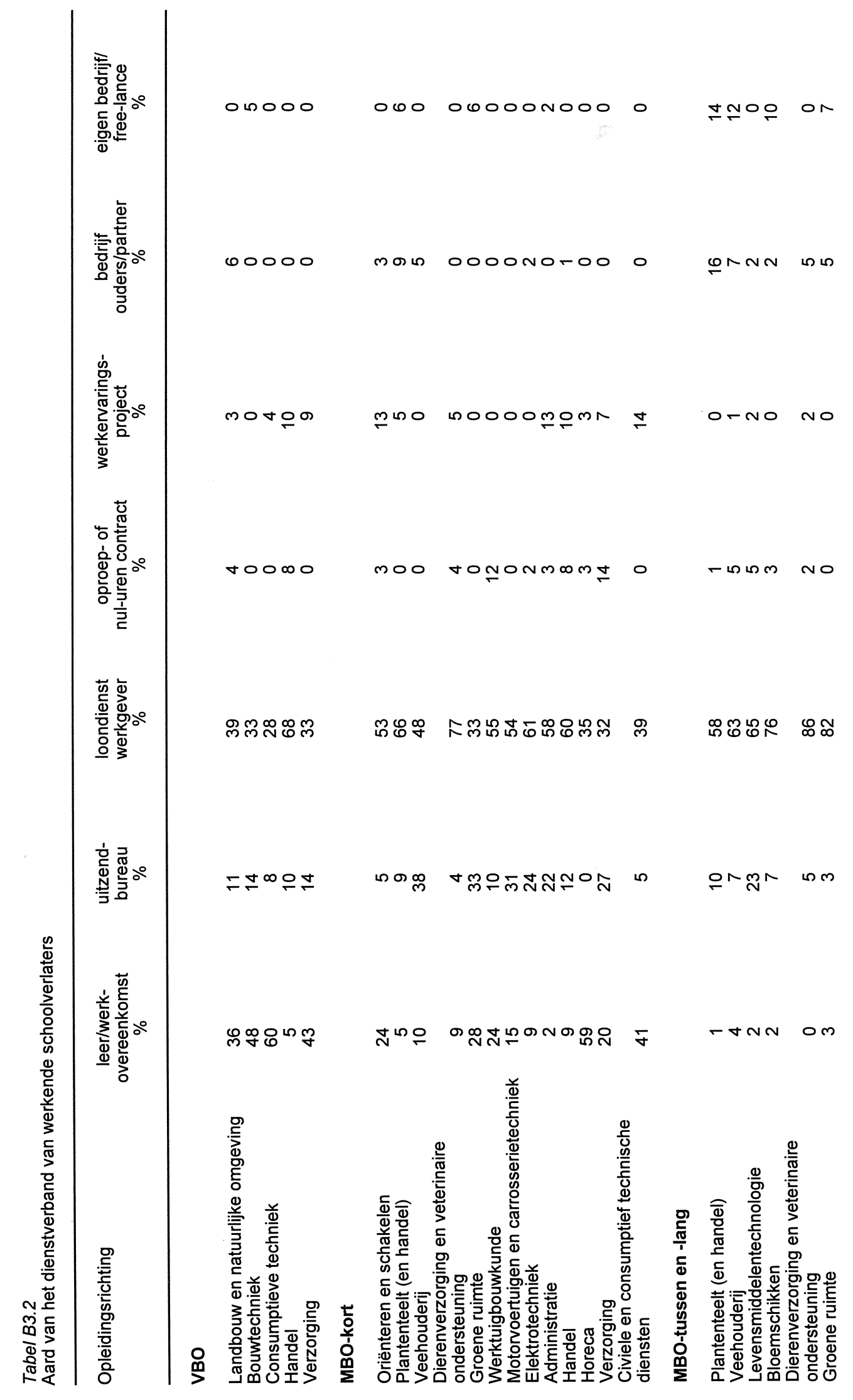




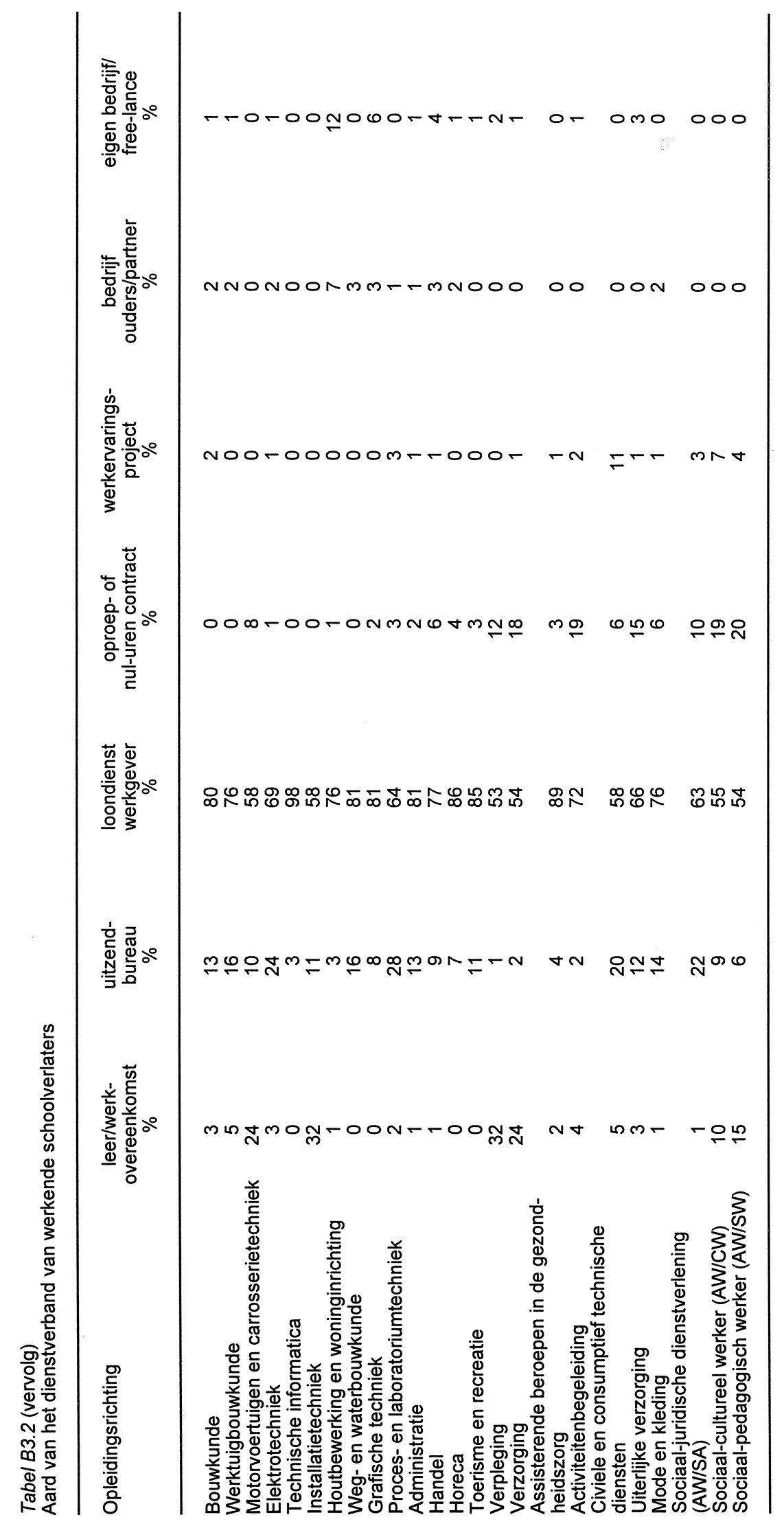


Tabel B3.3

Percentage werkende schoolverlaters met een flexibele aanstelling

Opleidingsrichting

VBO

Landbouw en natuurlijke omgeving

Bouwtechniek

Consumptieve techniek

Handel

Verzorging

MBO-kort

Oriënteren en schakelen Orienteren en schakelen Plantenteelt (en handel)

Veehouderij

Dierenverzorging en veterinaire ondersteuning

Groene ruimte

Werktuigbouwkunde

Motorvoertuigen en carrosserietechniek

Elektrotechniek

Administratie

Handel

Horeca

Verzorging

Civiele en consumptief technische diensten

MBO-tussen en -lang

Plantenteelt (en handel)

Veehouderij

Levensmiddelentechnologie

Bloemschikken

Dierenverzorging en veterinaire ondersteuning

Groene ruimte

Bouwkunde

Werktuigbouwkunde

Motorvoertuigen en carrosserietechniek

Elektrotechniek

Technische informatica

Installatietechniek

Houtbewerking en woninginrichting

Weg- en waterbouwkunde

Grafische techniek

Proces- en laboratoriumtechniek

Administratie

Handel

Horeca

Toerisme en recreatie

Verpleging

Verzorging

Assisterende beroepen in de gezondheidszorg

Activiteitenbegeleiding

Civiele en consumptief technische diensten

Uiterlijke verzorging

Mode en kleding

Sociaal-juridische dienstverlening (AW/SA)

Sociaal-cultureel werker (AW/CW)

Sociaal-pedagogisch werker (AW/SW)

Zie ook toelichting bladzijde 20 


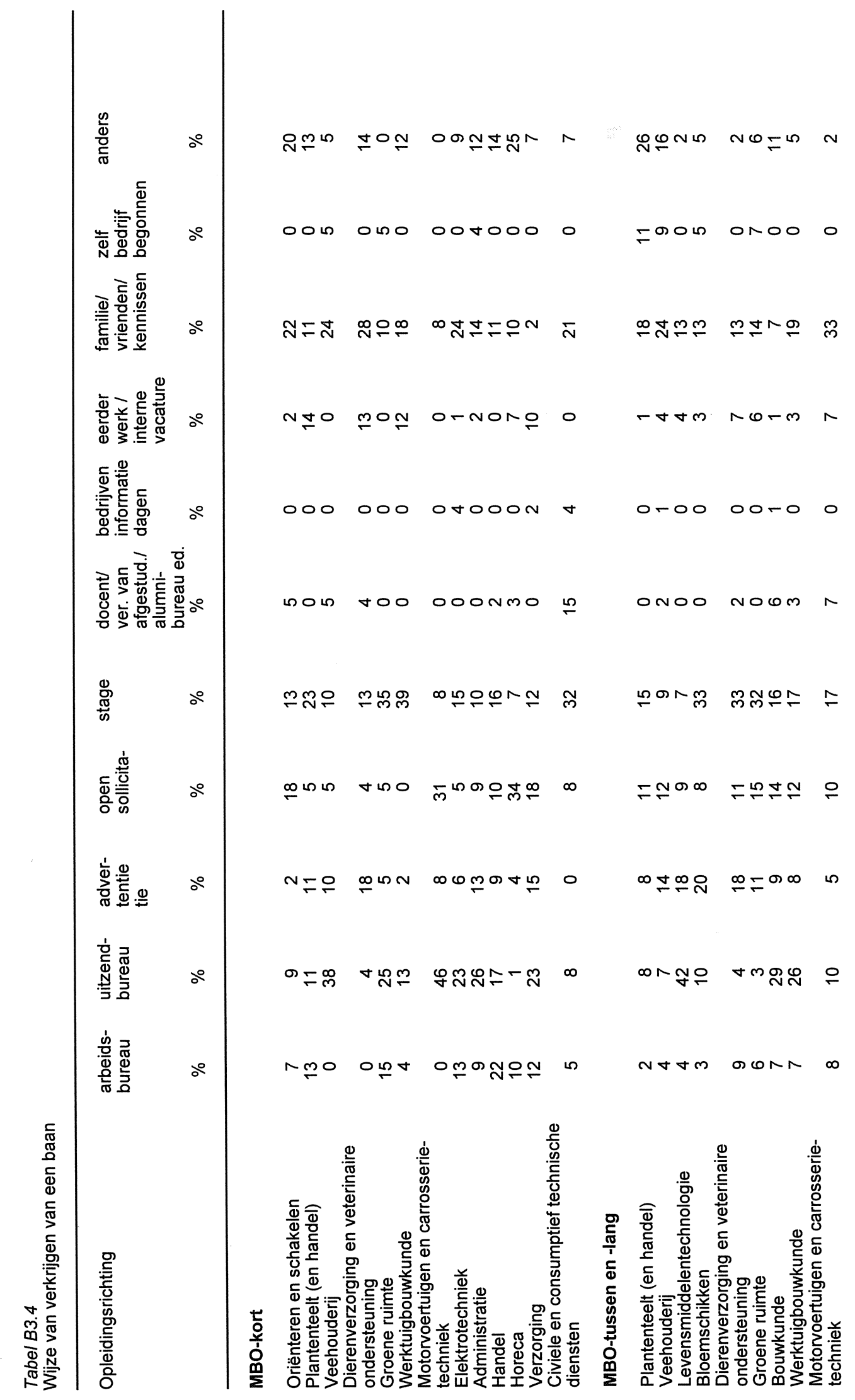




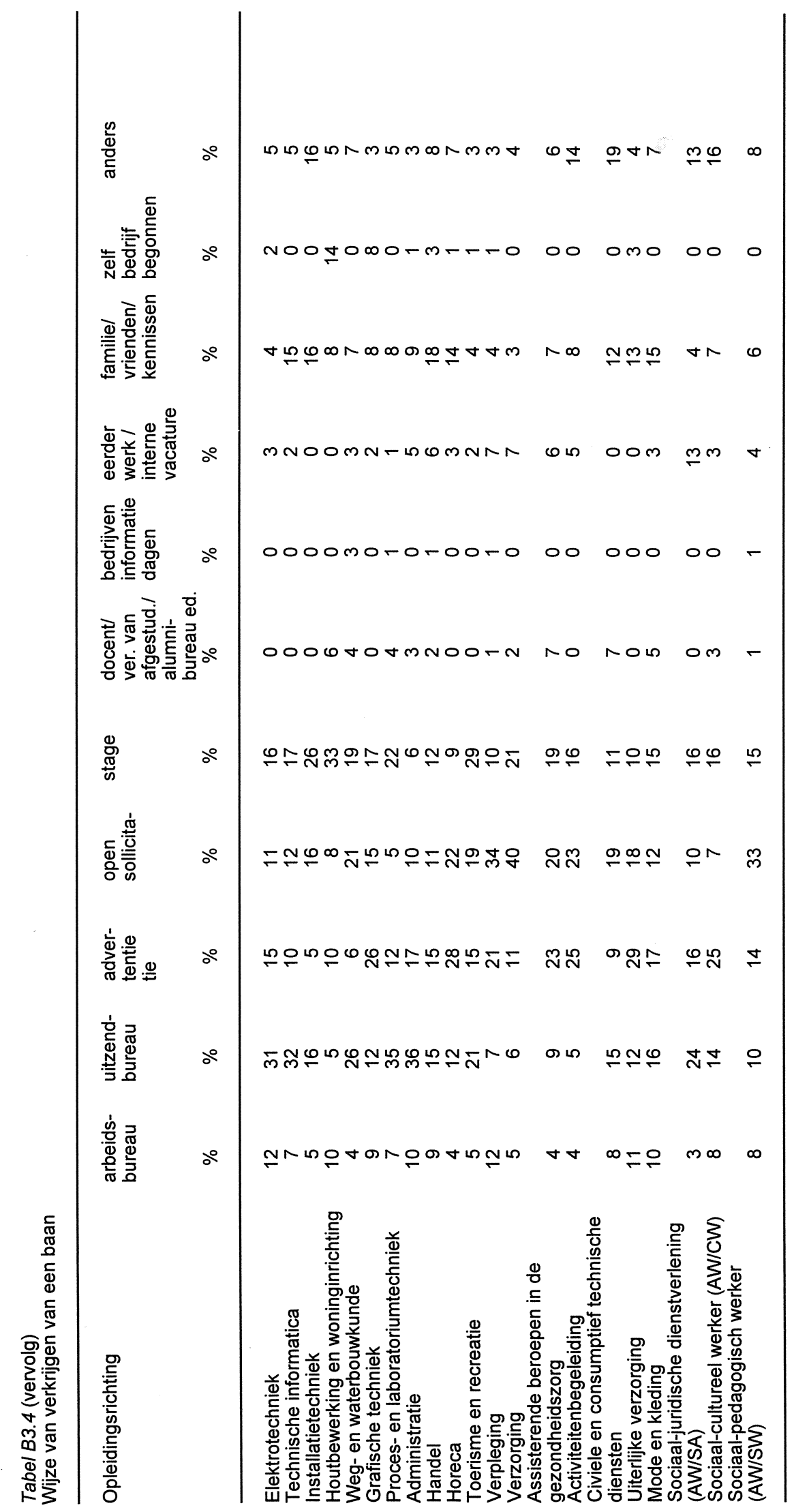


Tabel B3.5

Belangrijkste bedrijfsgroepen waarin schoolverlaters werkzaam zijn

\section{VBO Landbouw en natuurlijke omgeving}

Ov. gespec. detailh. in winkel

Dienstverl. tbv landb. (excl. veterin.dienst.)

Burgerl./utilit.;grond-/water-/wegenb. (excl. grondverz.)

Niet-gespec. detailh. in winkel

Vervoer over weg

Akker-/tuinbouw

Restaurants/cafetaria's/snackbars ed

\section{VBO Bouwtechniek}

Burgerl./utilit.;grond-/water-/wegenb. (excl. grondverz.)

Afwerken gebouwen

Vervaard. meubels

Bouwnijverheid

Akker-/tuinbouw

Uitgeverijen

Handel in/repar. auto s (1)

Niet-gespec. detailh. in winkel

Ov. gespec. detailh. in winkel

Activ. tbv of verwant aan financ. instell. (niet verzek. ed)

\section{VBO Consumptieve techniek}

Vervaard. ov. voedingsmid.

Restaurants/cafetaria's/snackbars ed

Hotels/pensions/conferentie-oorden

Overheidsdienst.

Welzijnszorg

5

VBO Handel

Ov. gespec. detailh. in winkel

Niet-gespec. detailh. in winkel

Post-/koeriersdiensten

Ov. zakelijke dienstverl. n.e.g.

VBO Verzorging

Welzijnszorg

Ov. dienstverlening

Restaurants/cafetaria's/snackbars ed

Niet-gespec. detailh. in winkel

\section{MBO Kort Oriënteren en schakelen}

Niet-gespec. detailh. in winkel

Welzijnszorg

Restaurants/cafetaria's/snackbars ed

Ov. gespec. detailh. in winkel

Gezondheidszorg

Vervaard. med. appar./instrum./orthop./prothese-art.

Afwerken gebouwen

Grooth. intermediaire goederen (excl. agrar.)/afval/schroot

Detailh. farmac./med. art./parfum/cosmet. in winkel

Vervoer over weg

Basisonderwijs voor leerplichtingen/speciaal onderwijs 
Tabel B3.5 (vervolg)

Belangrijkste bedrijfsgroepen waarin schoolverlaters werkzaam zijn

MBO Kort Plantenteelt (en handel)

Akker-/tuinbouw

Dienstverl. tbv landb. (excl. veterin.dienst.)

Grooth. landbouwprod./lev. dieren

Ov. dienstverlening

Verhuur bouw-/sloopmachines met bedienend personeel

MBO Kort Veehouderij

Slachterijen/vleesverwerking

Akker-/tuinbouw

Dienstverl. tbv landb. (excl. veterin.dienst.)

Niet-gespec. detailh. in winkel

Ov. gespec. detailh. in winkel

Fokken/houden dieren

Akker- en/of tuinb. comb. met fokken/houden dieren

Vervaard. diervoeder

Vervaard. houten emballage

Vervaard. mach./appar.

Vervaard. landbouwmach./-werkt.

Handel in/repar. auto s (1)

Grooth. intermediaire goederen (excl. agrar.)/afval/schroot

Veterinaire diensten

MBO Kort Dierenverzorging en veterinaire ondersteuning

Veterinaire diensten

Niet-gespec. detailh. in winkel

Akker-/tuinbouw

Ov. gespec. detailh. in winkel

Sport

\section{MBO Kort Groene ruimte}

Dienstverl. tbv landb. (excl. veterin.dienst.)

Akker-/tuinbouw

Ov. gespec. detailh. in winkel

Openbaar bestuur

Vervaard. diervoeder

Laad-/los-/overslagactiv./opslag

MBO Kort Werktuigbouwkunde

Vervaard. mach.prod./toepas.mech.energ.(excl.motorvoert.ed)

Vervaard. prod. metaal (excl. mach./transportmid.)

Industrie onbekend

Burgerl./utilit.;grond-/water-/wegenb. (excl. grondverz.)

Hotels/pensions/conferentie-oorden

Overheidsdienst.

Vervaard. ov. mach./appar. voor alg. gebr.

MBO Kort Motorvoertuigen en carrosserietechniek

Handel in/repar. auto s (1)

Aardolieverw.

Vervaard. metalen constructiew./ramen/deuren/kozijnen

Handel in/repar. auto s/motorfiets.;benzineservicestations

Grooth. voedings-/genotmid.

Vervoer over weg

Openbaar bestuu

Overheidsdienst. 
Tabel B3.5 (vervolg)

Belangrijkste bedrijfsgroepen waarin schoolverlaters werkzaam zijn

\section{MBO Kort Elektrotechniek}

Bouwinstallatie

Overheidsdienst.

Ov. gespec. detailh. in winkel

Gezondheidszorg

Milieudienstverlening

MBO Kort Administratie

Openbaar bestuur

Rechtsk. dienstverl./account./belastingconsul./holdings ed

Ov. gespec. detailh. in winkel

Vervaard. ov. voedingsmid.

Overheidsdienst.

MBO Kort Handel

Ov. gespec. detailh. in winkel

Niet-gespec. detailh. in winkel

Gespec. detailh. voed.-/genotmid. in winkel

\section{MBO Kort Horeca}

Restaurants/cafetaria's/snackbars ed 30

Hotels/pensions/conferentie-oorden $\quad 30$

$\begin{array}{ll}\text { Niet-gespec. detailh. in winkel } & 10\end{array}$

\section{MBO Kort Verzorging}

Welzijnszorg

Niet-gespec. detailh. in winkel

MBO Kort Civiele en consumptief technische diensten

Welzijnszorg
Restaurants/cafetaria's/snackbars ed
Vervaard. ov. voedingsmid.

Hotels/pensions/conferentie-oorden

Niet-gespec. detailh. in winkel

MBO Plantenteelt (en handel)

Akker-/tuinbouw

Dienstverl. tbv landb. (excl. veterin.dienst.)

MBO Veehouderij

Fokken/houden dieren

Dienstverl. tbv landb. (excl. veterin.dienst.)

Akker-/tuinbouw

BO Levensmiddelentechnologie

Vervaard. ov. voedingsmid.

Slachterijen/vleesverwerking

Groente-/fruitverwerking

Vervaard. zuivelprodukten

Niet-gespec. detailh. in winkel

\section{MBO Bloemschikken}

Ov. gespec. detailh. in winkel

Akker-/tuinbouw 
Tabel B3.5 (vervolg)

Belangrijkste bedrijfsgroepen waarin schoolverlaters werkzaam zijn

MBO Dierenverzorging en veterinaire ondersteuning

Ov. gespec. detailh. in winke

Veterinaire diensten

Natuurwet. speur-/ontwikkelingsw.

Cult. uitl.centra/openb. arch./musea/dieren-/plantentuin ed

Fokken/houden dieren

\section{MBO Groene ruimte}

Dienstverl. tbv landb. (excl. veterin.dienst.)

Ov. gespec. detailh. in winkel

\section{MBO Bouwkunde}

Burgerl./utilit.;grond-/water-/wegenb. (excl. grondverz.)

Architecten-/ingenieurs-/ov. techn.ontw.-/teken-/adviesbur.

Vervaard. timmerw.

Openbaar bestuur

\section{MBO Werktuigbouwkunde}

Vervaard. metalen constructiew./ramen/deuren/kozijnen

Bouwinstallatie

Vervaard. mach./appar

Vervaard. ov. mach./appar. voor alg. gebr.

Grooth. mach./appar./toebehoren

\section{MBO Motorvoertuigen en carrosserietechniek}

Handel in/repar. auto s (1)

Vervaard. schakel-/verdeelinricht.

Grooth. mach./appar./toebehoren

Bouwinstallatie

Vervoer over weg

Architecten-/ingenieurs-/ov. techn.ontw.-/teken-/adviesbur.

Grooth. intermediaire goederen (excl. agrar.)/afval/schroot

Reiniging gebouwen/transportmid. ed

Overheidsdienst.

\section{MBO Elektrotechniek}

Bouwinstallatie

Telecommunicatie

Grooth. mach./appar./toebehoren

Overheidsdienst.

\section{MBO Technische informatica}

Systeemontwikkelings-/systeemanalyse-/programmeerdienst.

Adviesbur. op gebied automat./systeemh

Grooth. mach./appar./toebehoren

Ov. gespec. detailh. in winke

Overheidsdienst

Bouwinstallatie

Onderwijs 
Tabel B3.5 (vervolg)

Belangrijkste bedrijfsgroepen waarin schoolverlaters werkzaam zijn

\section{MBO Installatietechniek}

Bouwinstallatie

Burgerl./utilit.;grond-/water-/wegenb. (excl. grondverz.)

Vervaard. ov. mach./appar. voor alg. gebr.

Vervaard. landbouwmach./-werkt.

Vervaard. ov. elektr. benodigdh. n.e.g

Vervoer per spoor

Telecommunicatie

Verhuur onroerend goed

MBO Houtbewerking en woninginrichting

Vervaard. meubels

Ov. gespec. detailh. in winke

Grooth. intermediaire goederen (excl. agrar.)/afval/schroot

Vervaard. timmerw.

Scheepsbouw/-reparatie

MBO Weg- en waterbouwkunde

Burgerl./utilit.;grond-/water-/wegenb. (excl. grondverz.)

Architecten-/ingenieurs-/ov. techn.ontw.-/teken-/adviesbur.

Openbaar bestuur

Overheidsdienst.

\section{MBO Grafische techniek}

Drukkerijen/aanverwante activ.

Reklamebureaus ed

Uitgeverijen

51

31
6

\section{MBO Proces- en laboratoriumtechniek}

Gezondheidszorg

Vervaard. farmac. prod.

Natuurwet. speur-/ontwikkelingsw.

Vervaard. chem. prod.

\section{MBO Administratie}

Rechtsk. dienstverl./account./belastingconsul./holdings ed

Ov. gespec. detailh. in winkel

Geldscheppende financ. instell.

\section{MBO Handel}

Ov. gespec. detailh. in winkel

\section{MBO Horeca}

Hotels/pensions/conferentie-oorden

\section{MBO Toerisme en recreatie}

Reisorgan./-bemid.;informatieverstrek. op gebied toerisme Hotels/pensions/conferentie-oorden 
Tabel B3.5 (vervolg)

Belangrijkste bedrijfsgroepen waarin schoolverlaters werkzaam zijn

MBO Verpleging

Welzijnszorg

Gezondheidszorg

MBO Verzorging

Welzijnszorg

Gezondheidszorg

MBO Assisterende beroepen en de gezondheidszorg

Gezondheidszorg

Detailh. farmac./med. art./parfum/cosmet. in winkel

\section{MBO Activiteitenbegeleiding}

Welzijnszorg

Gezondheidszorg

MBO Civele en consuptief technische diensten

Welzijnszorg

Gezondheidszorg

Restaurants/cafetaria's/snackbars ed

Kantines/catering

Overheidsdienst.

Hotels/pensions/conferentie-oorden

Burgerl./utilit.;grond-/water-/wegenb. (excl. grondverz.)

Reiniging gebouwen/transportmid. ed

MBO Uiterlijke verzorging

Ov. dienstverlening

Detailh. farmac./med. art./parfum/cosmet. in winkel

Ov. gespec. detailh. in winkel

\section{MBO Mode en Kleding}

Ov. gespec. detailh. in winkel

Grooth. ov. consumentenart.

Niet-gespec. detailh. in winkel

MBO Sociaal-juridische dienstverlening (AWISA)

Verpl. soc. verzekeringen

Uitzendbur./uitleenbedr./arbeidsbemid./testen/werven/select.

Openbaar bestuur

Ov. gespec. detailh. in winkel

Welzijnszorg

Vervoer over weg

Vervaard. ov. voedingsmid.

Gezondheidszorg

MBO Sociaal-cultureel werker (AWICW)

Welzijnszorg

Basisonderwijs voor leerplichtingen/speciaal onderwijs

Slachterijen/vleesverwerking

Vervaard. med. appar./instrum./orthop./prothese-art.

Cafes ed 
Tabel B3.5 (vervolg)

Belangrijkste bedrijfsgroepen waarin schoolverlaters werkzaam zijn

MBO Sociaal-pedagogisch werker (AWISW)

Welzijnszorg

Basisonderwijs voor leerplichtingen/speciaal onderwijs

70

Zie ook toelichting bladzijde 25 
Tabel B3.6

Belangrijkste beroepsgroepen waarin schoolverlaters werkzaam zijn

VBO Landbouw en natuurlijke omgeving

$\begin{array}{lr}\text { Verkopers } & 25 \\ \text { Agrarische arbeider } & 22 \\ \text { Elementaire beroepen } & 10 \\ \text { Hulpkrachten horeca en verzorging } & 7 \\ \text { Weg- en waterbouwkundige vakkrachten } & 7\end{array}$

VBO Bouwtechniek

Bouwvakkers

Aannemers en installateurs

Elementaire beroepen

Agrarische arbeider

Assembleurs

Chauffeurs

Verkopers

Commercieel employes

VBO Consumptieve techniek

Hulpkrachten horeca en verzorging

Bakkers en slagers

Elementaire beroepen

Verkopers

Aspirant politieagenten, soldaten en beveiligingshulpkrachten

VBO Handel

Verkopers

Receptionisten en administratieve employés

Chauffeurs

Hulpkrachten horeca en verzorging

BO Verzorging

Hulpkrachten horeca en verzorging

Elementaire beroepen

Verkopers

Receptionisten en administratieve employés

MBO Kort Oriënteren en schakelen

Elementaire beroepen

Hulpkrachten horeca en verzorging

Verkopers

Verpleeghulpen en leerling-verpleegkundigen

Agrarische arbeider

Receptionisten en administratieve employés

Productiemedewerker

Confectie-arbeiders

Monteurs

MBO Kort Plantenteelt (en handel)

Agrarische arbeider

Landbouwmachinebestuurders en vissers

Elementaire beroepen

Kantoorhulpen, inpakkers en colporteurs

Chauffeurs

Agrarische bedrijfshoofden

Weg-en waterbouwkundige vakkrachten 
Tabel B3.6 (vervolg)

Belangrijkste beroepsgroepen waarin schoolverlaters werkzaam zijn

MBO Kort Veehouderij

$\begin{array}{lr}\text { Agrarische arbeider } & 24 \\ \text { Productiemedewerker } & 19 \\ \text { Verkopers } & 14 \\ \text { Elementaire beroepen } & 10 \\ \text { Landbouwmachinebestuurders en vissers } & 10 \\ \text { Bouwvakkers } & 5 \\ \text { Assembleurs } & 5 \\ \text { Monteurs en controleurs elektrotechnische producten } & 5 \\ \text { Mechanisch operators } & 5 \\ \text { Verplegenden en doktersassistenten } & 5\end{array}$

MBO Kort Dierenverzorging en veterinaire ondersteuning

Verplegenden en doktersassistenten

Agrarische arbeider

Verkopers

Receptionisten en administratieve employés

Hulpkrachten horeca en verzorging

MBO Kort Groene ruimte

$\begin{array}{lr}\text { Agrarische bedrijfshoofden } & 53 \\ \text { Agrarische arbeider } & 32 \\ \text { Landbouwmachinebestuurders en vissers } & 10 \\ \text { Kantoorhulpen, inpakkers en colporteurs } & 5\end{array}$

MBO Kort Werktuigbouwkunde

Bankwerkers en lassers

Metaalarbeiders

Monteurs

Bouwvakkers

Weg-en waterbouwkundige arbeiders

Aannemers en installateurs

MBO Kort Motorvoertuigen en carrosserietechniek

$\begin{array}{lr}\text { Monteurs } & 46 \\ \text { Elementaire beroepen } & 31 \\ \text { Metaalarbeiders } & 8 \\ \text { Chauffeurs } & 8 \\ \text { Aannemers en installateurs } & 8\end{array}$

Aannemers en installateurs 8

\section{MBO Kort Elektrotechniek}

Elektromonteurs

Monteurs en controleurs elektrotechnische producten 13

9

Aspirant politieagenten, soldaten en beveiligingshulpkrachten

Elektronicamonteurs

Elementaire beroepen

Aannemers en installateurs

\section{MBO Kort Administratie}

Receptionisten en administratieve employés 36

Boekhouders en secretaresses 16

(2) 12

Elementaire beroepen 8 
Tabel B3.6 (vervolg)

Belangrijkste beroepsgroepen waarin schoolverlaters werkzaam zijn

\section{MBO Kort Handel}

Verkopers

Chauffeurs

Hulpkrachten horeca en verzorging

Elementaire beroepen

\section{MBO Kort Horeca}

Hulpkrachten horeca en verzorging

Verzorgend personeel

Verkopers

Aspirant politieagenten, soldaten en beveiligingshulpkrachten

MBO Kort Verzorging

Verzorgend personeel

Verpleeghulpen en leerling-verpleegkundigen

Hulpkrachten horeca en verzorging

Verkopers

Elementaire beroepen

Productiemedewerker

MBO Kort Civiele en consumptief technische diensten

Hulpkrachten horeca en verzorging

Bakkers en slagers

Verzorgend personeel

Elementaire beroepen

MBO Plantenteelt (en handel)

Agrarische arbeider

Agrarische bedrijfshoofden

Elementaire beroepen

Verkopers

Landbouwmachinebestuurders en vissers

MBO Veehouderij

Agrarische arbeider

Landbouwmachinebestuurders en vissers

Agrarische bedrijfshoofden

Verkopers

Chauffeurs

\section{MBO Levensmiddelentechnologie}

Procesoperators

Laboranten

Mechanisch operators

Elementaire beroepen

Verkopers

Kantoorhulpen, inpakkers en colporteurs

MBO Bloemschikken

\section{Verkopers}

Agrarische vakkrachten

Winkeliers

Agrarische arbeider

Agrarische bedrijfshoofden

Hulpkrachten horeca en verzorging

.


Tabel B3.6 (vervolg)

Belangrijkste beroepsgroepen waarin schoolverlaters werkzaam zijn

MBO Dierenverzorging en veterinaire ondersteuning

Verkopers

Verplegenden en doktersassistenten

Agrarische arbeider

Agrarische vakkrachten

MBO Groene ruimte

Agrarische bedrijfshoofden

Agrarische arbeider

Landbouwmachinebestuurders en vissers

MBO Bouwkunde

Aannemers en installateurs

Productieplanners

Bouwvakkers

\section{MBO Werktuigbouwkunde}

Monteurs

Metaalarbeiders

Bankwerkers en lassers

Aannemers en installateurs

Elektromonteurs

MBO Motorvoertuigen en carrosserietechniek

Monteurs

Elektromonteurs

Elementaire beroepen

Metaalarbeiders

Weg- en waterbouwkundige vakkrachten

Receptionisten en administratieve employés

Monteurs en controleurs elektrotechnische producten

Aspirant politieagenten, soldaten en beveiligingshulpkrachte

MBO Elektrotechniek

Elektromonteurs

Monteurs

Elektronicamonteurs

Programmeurs

MBO Technische informatica

Programmeurs

Elektronicamonteurs

Monteurs

MBO Installatietechniek

Elektromonteurs

Bouwvakkers

Aannemers en installateurs

Productiemedewerker

Metaalarbeiders

Monteurs en controleurs elektrotechnische producten

Monteurs

Elektronicamonteurs 
Tabel B3.6 (vervolg)

Belangrijkste beroepsgroepen waarin schoolverlaters werkzaam zijn

MBO Houtbewerking en woninginrichting

Aannemers en installateurs

Verkopers

Commercieel employes

Bouwvakkers

Confectie-arbeiders

Monteurs

MBO Weg- en waterbouwkunde

Weg- en waterbouwkundige vakkrachten 43

Aannemers en installateurs

MBO Grafische techniek

Grafisch productiepersoneel

Grafische vakkrachten

Grafisch ontwerpers

MBO Proces- en laboratoriumtechniek

Laboranten
Apothekersassistenten en medisch laboranten
Procesoperators
Bouwvakkers

Apothekersassistenten en medisch laboranten $\quad 15$

MBO Administratie

Boekhouders en secretaresses

Receptionisten en administratieve employés

Commercieel employes

Verkopers

\section{MBO Handel}

Verkopers

Winkeliers

Receptionisten en administratieve employés

Commercieel employes

Elementaire beroepen

Boekhouders en secretaresses

\section{MBO Horeca}

Hulpkrachten horeca en verzorging

Bedrijfshoofden horeca

Receptionisten en administratieve employés

Verzorgend personeel

Stewards

Activiteitenbegeleiders en medewerkers arbeidsbemiddeling

MBO Toerisme en recreatie

Commercieel employes

Receptionisten en administratieve employés

Stewards

Boekhouders en secretaresses 
Tabel B3.6 (vervolg)

Belangrijkste beroepsgroepen waarin schoolverlaters werkzaam zijn

MBO Verpleging

Verpleeghulpen en leerling-verpleegkundigen

Verplegenden en doktersassistenten

Ziekenverzorgenden

Hulpkrachten horeca en verzorging

15

BO Verzorging

Verzorgend personee

Verpleeghulpen en leerling-verpleegkundigen

Verplegenden en doktersassistenten

Ziekenverzorgenden

Hulpkrachten horeca en verzorging

MBO Assisterende beroepen en de gezondheidszorg

Verplegenden en doktersassistenten

Apothekersassistenten en medisch laboranten

Verkopers

MBO Activiteitenbegeleiding

Activiteitenbegeleiders en medewerkers arbeidsbemiddeling

Verzorgend personee

MBO Civele en consumptief technische diensten

Hulpkrachten horeca en verzorging

Elementaire beroepen

MBO Uiterlijke verzorging

Verzorgend personeel

Verkopers

Receptionisten en administratieve employés

Hulpkrachten horeca en verzorging

\section{MBO Mode en Kleding}

Verkopers

Confectie-arbeiders

Receptionisten en administratieve employés

Schoen- en kleermakers

Elementaire beroepen

MBO Sociaal-juridische dienstverlening (AWISA)

Activiteitenbegeleiders en medewerkers arbeidsbemiddeling

Boekhouders en secretaresses

Receptionisten en administratieve employés

Verkopers

Commercieel employes

Productiemedewerker

MBO Sociaal-cultureel werker (AWICW)

Verzorgend personeel

Hulpkrachten horeca en verzorging

Receptionisten en administratieve employés

Productiemedewerker

Elementaire beroepen

Mechanisch operators 
Tabel B3.6 (vervolg)

Belangrijkste beroepsgroepen waarin schoolverlaters werkzaam zijn

$\%$

MBO Sociaal-pedagogisch werker (AW/SW)

Verzorgend personeel

Hulpkrachten horeca en verzorging

Activiteitenbegeleiders en medewerkers arbeidsbemiddeling

Verkopers

47

21

8

Zie ook toelichting bladzijde 29 
Tabel B3.7

Grootte van de organisatie waarin schoolverlaters werkzaam zijn

\begin{tabular}{|c|c|c|c|c|c|}
\hline Opleidingsrichting & $\begin{array}{c}1 \text { pers } \\
\%\end{array}$ & $\begin{array}{c}2 \mathrm{t} / \mathrm{m} 9 \\
\text { pers } \\
\%\end{array}$ & $\begin{array}{l}10 \mathrm{t} / \mathrm{m} 99 \\
\text { pers } \\
\%\end{array}$ & $\begin{array}{c}100 \mathrm{t} / \mathrm{m} \\
999 \text { pers } \\
\%\end{array}$ & $\begin{array}{c}>=1000 \\
\text { pers } \\
\%\end{array}$ \\
\hline
\end{tabular}

MBO-kort

Oriënteren en schakelen

Plantenteelt (en handel)

Veehouderij

$0 \quad 28 \quad 60$

Dierenverzorging en veterinaire

ondersteuning

Groene ruimte

Werktuigbouwkunde

0

38

43

$8 \quad 5$

Motorvoert

Elektrotechniek

Administratie

Handel

Horeca

Verzorging

Civiele en consumptief technische

diensten

1

$\begin{array}{rr}14 & 14 \\ 6 & 0\end{array}$

MBO-tussen en -lang

Plantenteelt (en handel)

Veehouderij

Levensmiddelentechnologie

Bloemschikken

Dierenverzorging en veterinaire

ondersteuning

Groene ruimte

Bouwkunde

Werktuigbouwkunde

Motorvoertuigen en carrosserie-

techniek

Elektrotechniek

Technische informatica

Installatietechniek

Houtbewerking en woninginrichting

Weg-en waterbouwkunde

Grafische techniek

Proces- en laboratoriumtechniek

Administratie

Handel

Horeca

Toerisme en recreatie

Verpleging

Verzorging

Assisterende beroepen in de

gezondheidszorg

Activiteitenbegeleiding

Civiele en consumptief technische

diensten

Uiterlijke verzorging

Mode en kleding

Sociaal-juridische dienstverlening

(AW/SA)

Sociaal-cultureel werker (AW/CW)

Sociaal-pedagogisch werker

(AW/SW)

Zie ook toelichting bladzijde 30 
Tabel B3.8

Beloning van werkende schoolverlaters

\begin{tabular}{lcc}
\hline Opleidingsrichting & $\begin{array}{c}\text { gemiddeld } \\
\text { bruto maandloon } \\
\text { guldens }\end{array}$ & $\begin{array}{c}\text { gemiddeld } \\
\text { bruto uurloon } \\
\text { guldens }\end{array}$ \\
\hline
\end{tabular}

\section{VBO}

Landbouw en natuurlijke omgeving

Bouwtechniek

Consumptieve techniek

Handel

Verzorging

$\begin{array}{ll}1.146 & 8,00 \\ 1.363 & 9,35 \\ 1.220 & 8,32 \\ 1.256 & 8,87 \\ 1.041 & 7,59\end{array}$

MBO-kort

Oriënteren en schakelen Orienteren en schakelen

1.219

Plantenteelt (en handel)

1.874

1.625

1.393

Dierenverzorging en veterinaire ondersteuning

1.393

Groene ruimte

1.728
2.043

$\begin{array}{ll}\text { Motorvoertuigen en carrosserietechniek } & 2.267 \\ \text { Elektrotechniek } & 1.894\end{array}$

Elektrotechniek

Administratie

1.812

1.568

Handel 1.692

$\begin{array}{lr}\text { Horeca } & 1.692 \\ \text { Verzorging } & 1.225\end{array}$

Civiele en consumptief technische diensten $\quad 1.878$

8,22

11,40

10,66

11,16

9,96

11,63

11,75

11,57

11,65

10,33

11,45

9,08

12,34

\section{MBO-tussen en -lang}

\begin{tabular}{llr} 
Plantenteelt (en handel) & 2.351 & 14,15 \\
Veehouderij & 2.155 & 13,42 \\
Levensmidddelentechnologie & 2.503 & 15,08 \\
Bloemschikken & 1.831 & 11,45 \\
Dierenverzorging en veterinaire ondersteuning & 2.023 & 12,33 \\
Groene ruimte & 2.325 & 13,95 \\
Bouwkunde & 2.835 & 16,53 \\
Werktuigbouwkunde & 2.516 & 14,52 \\
Motorvoertuigen en carrosserietechniek & 1.925 & 11,70 \\
Elektrotechniek & 2.432 & 14,43 \\
Technische informatica & 2.760 & 16,03 \\
Installatietechniek & 1.744 & 11,07 \\
Houtbewerking en woninginrichting & 2.545 & 15,19 \\
Weg-en waterbouwkunde & 2.622 & 15,34 \\
Grafische techniek & 2.371 & 14,55 \\
Proces- en laboratoriumtechniek & 2.545 & 15,97 \\
Administratie & 2.115 & 13,05 \\
Handel & 2.011 & 12,54 \\
Horeca & 2.707 & 16,44 \\
Toerisme en recreatie & 2.258 & 13,97 \\
Verpleging & 2.094 & 14,18 \\
Verzorging & 1.745 & 12,71 \\
Assisterende beroepen in de gezondheidszorg & 2.093 & 13,95 \\
Activiteitenbegeleiding & 2.020 & 15,85 \\
Civiele en consumptief technische diensten & 2.155 & 14,49 \\
Uiterlijke verzorging & 1.605 & 11,62 \\
Mode en kleding & 1.625 & 10,97 \\
Sociaal-juridische dienstverlening (AW/SA) & 2.263 & 15,08 \\
Sociaal-cultureel werker (AW/CW) & 1.886 & 13,78 \\
Sociaal-pedagogisch werker (AW/SW) & 1.730 & 12,87 \\
\hline
\end{tabular}

Zie ook toelichting bladzijde 31 
Tabel B3.9

Vereist opleidingsniveau voor de huidige functie volgens de schoolverlaters en de werkgever

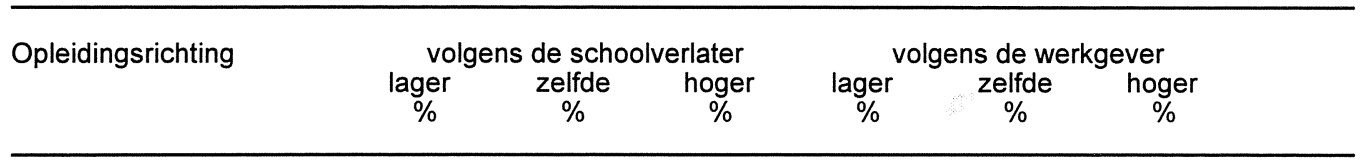

VBO

Landbouw en natuurlijke

omgeving

Bouwtechniek

Consumptieve techniek

Handel

Verzorging

$x \quad x$

0

12

20

MBO-kort

Oriënteren en schakelen 83

Plantenteelt (en handel)

Veehouderij

45

Dierenverzorging en veterinaire

ondersteuning

Groene ruimte

Werktuigbouwkunde

Motorvoertuigen en carrosserie-

techniek

Elektrotechniek

Administratie

Handel

Horeca

Verzorging

Civiele en consumptief

technische diensten

\section{MBO-tussen en -lang}

Plantenteelt (en handel)

Veehouderij

Levensmiddelentechnologie 44

Bloemschikken 27

Dierenverzorging en veterinaire

ondersteuning

Groene ruimte

Bouwkunde

Werktuigbouwkunde

Motorvoertuigen en carrosserie-

techniek

Elektrotechniek

Installatietechniek

Houtbewerking en woning-

inrichting

Weg-en waterbouwkunde

Grafische techniek

Proces- en laboratorium-

techniek

Administratie

Handel

Horeca

en recreatie

Verpleging

Verzorging

Assisterende beroepen in de

gezondheidszorg

Activiteitenbegeleiding

Civiele en consumptief

technische diensten

$\begin{array}{ll}45 & 54 \\ 49 & 5 \\ 44 & 5 \\ 27 & 73 \\ 39 & 61 \\ 37 & 63 \\ 21 & 76 \\ 35 & 65 \\ 68 & \\ 26 & 32 \\ 15 & 72 \\ 58 & 75 \\ 26 & 42 \\ 17 & 74 \\ 20 & 77 \\ 38 & \\ 32 & 62 \\ 43 & 56 \\ 42 & 57 \\ 25 & 73 \\ 23 & 77 \\ 28 & 72 \\ 24 & 76 \\ 21 & 76 \\ 52 & \end{array}$

$x$
62
92
65

65

70

$x$
14
8
23
10

26
35
0
12
26

$\begin{array}{lr}71 & 3 \\ 55 & 10 \\ 87 & 13 \\ 62 & 26 \\ 58 & 16\end{array}$

12

$\begin{array}{llll}0 & 28 & 71 & 1 \\ 3 & 13 & 87 & 0 \\ 3 & 10 & 86 & 5\end{array}$

$47 \quad 0$


Tabel B3.9 (vervolg)

Vereist opleidingsniveau voor de huidige functie volgens de schoolverlaters en de werkgever

\begin{tabular}{lcccccc}
\hline Opleidingsrichting & \multicolumn{3}{c}{ volgens de schoolverlater } & \multicolumn{3}{c}{ volgens de werkgever } \\
& $\begin{array}{l}\text { lager } \\
\%\end{array}$ & $\begin{array}{c}\text { zelfde } \\
\%\end{array}$ & $\begin{array}{c}\text { hoger } \\
\%\end{array}$ & $\begin{array}{c}\text { lager } \\
\text { zelfde } \\
\%\end{array}$ & $\begin{array}{c}\text { hoger } \\
\%\end{array}$ \\
\hline $\begin{array}{l}\text { Uiterlijke verzorging } \\
\begin{array}{l}\text { Mode en kleding } \\
\text { Sociaal-juridische dienst- }\end{array}\end{array}$ & 45 & 53 & 1 & 47 & 51 & 2 \\
$\begin{array}{l}\text { verlening (AW/SA) } \\
\text { Sociaal-cultureel werker }\end{array}$ & 21 & 72 & 7 & 23 & 68 & 9 \\
$\begin{array}{l}\text { (AW/CW) } \\
\text { Sociaal-pedagogisch werker }\end{array}$ & 32 & 65 & 3 & 32 & 68 & 0 \\
(AW/SW) & 23 & 75 & 1 & 29 & 70 & 1 \\
Totaal & 34 & 60 & 6 & 33 & 60 & 7 \\
\hline
\end{tabular}

$\mathrm{x}=$ vraag niet opgenomen

Zie ook toelichting bladzijde 32 
Tabel B3.10

Vereiste opleidingsrichting voor de huidige functie volgens de schoolverlaters en de werkgever

\begin{tabular}{|c|c|c|c|c|c|c|}
\hline \multirow[t]{2}{*}{ Opleidingsrichting } & \multicolumn{3}{|c|}{ volgens de schoolverlater } & \multicolumn{3}{|c|}{ volgens de werkgever } \\
\hline & $\begin{array}{l}\text { eigen/ } \\
\text { verwante } \\
\text { richting } \\
\%\end{array}$ & $\begin{array}{c}\text { andere } \\
\text { richting } \\
\%\end{array}$ & $\begin{array}{l}\text { geen } \\
\text { richting } \\
\%\end{array}$ & $\begin{array}{l}\text { eigen/ } \\
\text { verwante } \\
\text { richting } \\
\%\end{array}$ & $\begin{array}{c}\text { andere } \\
\text { richting } \\
\%\end{array}$ & $\begin{array}{c}\text { geen } \\
\text { richting } \\
\%\end{array}$ \\
\hline
\end{tabular}

VBo

Landbouw en natuurlijke omgeving

Bouwtechniek

Consumptieve techniek

Handel

Verzorging

$x$

55

64

56
37

MBO-kort

Oriënteren en schakelen

Plantenteelt (en handel)

Veehouderij

62
43

Dierenverzorging en

veterinaire ondersteuning

Groene ruimte

Werktuigbouwkunde

Motorvoertuigen en carrosserie-

techniek

Elektrotechniek $\quad 64$

Administratie $\quad 49$

Hande

Horeca

Verzorging

Civiele en consumptief

technische diensten

$\begin{array}{rr}x & x \\ 9 & 36 \\ 0 & 36 \\ 5 & 39 \\ 18 & 45\end{array}$

$\begin{array}{lrl}41 & 9 & 51 \\ 57 & 0 & 43 \\ 56 & 4 & 40 \\ 49 & 12 & 39 \\ 24 & 14 & 62\end{array}$

MBO-tussen en -lang

Plantenteelt (en handel)

Veehouderij

Levensmiddelentechnologie $\quad 59$

Bloemschikken

Dierenverzorging en

veterinaire ondersteuning

Groene ruimte

Bouwkunde

Werktuigbouwkunde

Motorvoertuigen en carrosserie-

techniek

Elektrotechniek

Technische informatica

Installatietechniek

Houtbewerking en woning-

inrichting

Weg-en waterbouwkunde

Grafische techniek

Proces- en laboratorium-

techniek

Administratie

Handel

Horeca

Toerisme en recreatie

Verpleging

Verzorging

Assisterende beroepen in de

gezondheidszorg

Activiteitenbegeleiding

53
84
79
74
78
94
91
73
69
59
76
75
86
84
88
80

$\begin{array}{rrrrr}19 & 59 & 22 & 12 & 66 \\ 8 & 30 & 52 & 5 & 43 \\ 5 & 52 & 38 & 0 & 62 \\ 28 & 43 & 28 & 22 & 50 \\ 5 & 15 & 70 & 0 & 30 \\ 5 & 15 & 63 & 3 & 35 \\ 0 & 17 & 75 & 8 & 17 \\ 11 & 25 & 63 & 7 & 30 \\ 16 & 35 & 46 & 8 & 45 \\ 17 & 44 & 28 & 9 & 62 \\ 5 & 15 & 76 & 2 & 22 \\ 9 & 39 & 45 & 6 & 48 \\ 4 & 17 & 79 & 0 & 21\end{array}$

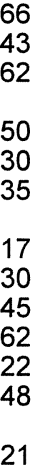

$\begin{array}{rrrrr}3 & 27 & 56 & 2 & 42 \\ 9 & 36 & 48 & 7 & 44 \\ 9 & 32 & 61 & 9 & 29 \\ 5 & 10 & 82 & 4 & 14 \\ 7 & 16 & 64 & 4 & 31 \\ 4 & 12 & 76 & 2 & 22 \\ 0 & 6 & 90 & 1 & 9 \\ 8 & 11 & 77 & 6 & 17\end{array}$

$29 \quad 17 \quad 52$

$\begin{array}{rr}9 & 85 \\ 14 & 70\end{array}$


Tabel B3.10 (vervolg)

Vereiste opleidingsrichting voor de huidige functie volgens de schoolverlaters en de werkgever

\begin{tabular}{|c|c|c|c|c|c|c|}
\hline Opleidingsrichting & $\begin{array}{l}\text { volgens } \\
\text { eigen/ } \\
\text { verwante } \\
\text { richting } \\
\%\end{array}$ & $\begin{array}{c}\text { de schoo } \\
\text { andere } \\
\text { richting } \\
\% \\
\%\end{array}$ & $\begin{array}{c}\text { erlater } \\
\text { geen } \\
\text { richting } \\
\% \\
\%\end{array}$ & $\begin{array}{l}\quad \text { volge } \\
\text { eigen/ } \\
\text { verwante } \\
\text { richting } \\
\%\end{array}$ & $\begin{array}{c}\text { רs de wer } \\
\text { andere } \\
\text { richting } \\
\% \\
\%\end{array}$ & $\begin{array}{c}\text { ever } \\
\text { geen } \\
\text { richting } \\
\%\end{array}$ \\
\hline \multirow{4}{*}{$\begin{array}{l}\text { Civiele en consumptief } \\
\text { technische diensten } \\
\text { Uiterlijke verzorging } \\
\text { Mode en kleding } \\
\text { Sociaal-juridische dienst- } \\
\text { verlening (AW/SA) } \\
\text { Sociaal-cultureel werker } \\
\text { (AW/CW) } \\
\text { Sociaal-pedagogisch werker } \\
\text { (AW/SW) }\end{array}$} & $\begin{array}{l}66 \\
68 \\
60\end{array}$ & $\begin{array}{r}13 \\
9 \\
9\end{array}$ & $\begin{array}{l}21 \\
23 \\
30\end{array}$ & $\begin{array}{l}49 \\
66 \\
52\end{array}$ & $\begin{array}{l}4 \\
9 \\
8\end{array}$ & $\begin{array}{l}48 \\
25 \\
40\end{array}$ \\
\hline & 75 & 4 & 21 & 67 & 9 & 24 \\
\hline & 81 & 3 & 16 & 75 & 3 & 22 \\
\hline & 78 & 5 & 17 & 72 & 4 & 24 \\
\hline
\end{tabular}

$\mathrm{x}=$ vraag niet opgenomen

Zie ook toelichting bladzijde 33 
Tabel B3.11

Gewenste en feitelijke wekelijkse arbeidsduur van werkende schoolverlaters

\begin{tabular}{lcc}
\hline Opleidingsrichting & $\begin{array}{c}\text { gewenste wekelijkse } \\
\text { arbeidsduur } \\
\text { uren }\end{array}$ & $\begin{array}{c}\text { feitelijke wekelijkse } \\
\text { arbeidsduur } \\
\text { uren }\end{array}$ \\
\hline
\end{tabular}

VBO

Landbouw en natuurlijke omgeving

Bouwtechniek

Consumptieve techniek

Handel

38,1

$36,0 \quad 34,2$

$37,6 \quad 34,0$

$36,6 \quad 28,8$

MBO-kort

Oriënteren en schakelen Orienteren en schakelen

35,6

Plantenteelt (en handel)

34,7

34,3

Veehouderij

Dierenverzorging en veterinaire ondersteuning

Groene ruimte

Werktuigbouwkunde

Motorvoertuigen en carrosserietechniek

Elektrotechniek

Administratie

Handel

Horeca

41,1

39,1

38,1

33,9

$42,0 \quad 38,3$

$37,4 \quad 40,1$

$37,7 \quad 41,5$

$41,0 \quad 39,2$

$37,5 \quad 36,3$

$37,2 \quad 32,4$

$39,3 \quad 35,3$

Verzorging

36,3

31,2

Civiele en consumptief technische diensten

33,2

36,3

MBO-tussen en -lang

Plantenteelt (en handel)

Veehouderij

Levensmiddelentechnologie

Bloemschikken

Dierenverzorging en veterinaire ondersteuning

Groene ruimte

Bouwkunde

Werktuigbouwkunde

Motorvoertuigen en carrosserietechniek

Elektrotechniek

Technische informatica

Installatietechniek

Houtbewerking en woninginrichting

Weg-en waterbouwkunde

Grafische techniek

Proces- en laboratoriumtechniek

Administratie

Handel

Horeca

Toerisme en recreatie

Verpleging

Verzorging

$42,5 \quad 42,2$

$43,3 \quad 42,9$

$40,6 \quad 38,9$

$36,4 \quad 37,5$

$35,8 \quad 38,2$

$40,9 \quad 39,8$

$40,1 \quad 40,1$

$40,6 \quad 40,8$

$40,5 \quad 37,2$

$38,8 \quad 39,7$

$37,8 \quad 40,4$

$38,7 \quad 37,2$

$38,1 \quad 39,5$

$40,8 \quad 40,5$

38,2

$36,9 \quad 37,5$

$38,3 \quad 38,5$

$38,6 \quad 37,4$

$40,1 \quad 39,3$

$37,4 \quad 38,2$

$35,2 \quad 35,7$

36,5

$\begin{array}{llr}\text { Assisterende beroepen in de gezondheidszorg } & 35,9 & 35,0 \\ \text { Activiteitenbegeleiding } & 33,1 & 30,7\end{array}$

Civiele en consumptief technische diensten $\quad 36,7 \quad 34,6$

$\begin{array}{lll}\text { Uiterlijke verzorging } & 35,4 & 32,3\end{array}$

36,3

Sociaal-juridische dienstverlening (AW/SA) $\quad 35,3 \quad 35,2$

Sociaal-cultureel werker (AW/CW) $34,9 \quad 33,6$

$\begin{array}{lll}\text { Sociaal-pedagogisch werker (AW/SW) } & 35,9 & 33,2\end{array}$

Zie ook toelichting bladzijde 34 
Tabel B3.12

Oordeel van de werkende schoolverlaters over de aansluiting tussen de afgesloten opleiding en de huidige functie

\begin{tabular}{lccc}
\hline Opleidingsrichting & goed \\
$\%$ & $\begin{array}{c}\text { voldoende } \\
\%\end{array}$ & $\begin{array}{c}\text { matig } \\
\%\end{array}$ & $\begin{array}{c}\text { slecht } \\
\%\end{array}$ \\
\hline
\end{tabular}

\section{MBO-kort}

Oriënteren en schakelen

Plantenteelt (en handel)

Veehouderij 25

Dierenverzorging en veterinaire ondersteuning 10

Groene ruimte

Werktuigbouwkunde

Motorvoertuigen en carrosserietechniek

Elektrotechniek 23

Administratie 23

Horeca

Verzorging

Civiele en consumptief technische diensten

$\begin{array}{ll}3 & 49 \\ 6 & 44 \\ 5 & 30 \\ 0 & 22 \\ 0 & 45 \\ 9 & 30 \\ 3 & 38 \\ 3 & 48 \\ 3 & 43 \\ 1 & 41 \\ 3 & 33 \\ 9 & 47 \\ 3 & 35\end{array}$

MBO-tussen en -lang

Plantenteelt (en handel)

Veehouderij

Levensmiddelentechnologie

$49-18-20$

Bloemschikken

44

30

Dierenverzorging en veterinaire ondersteuning

Groene ruimte

20
16
35
40
15
0
15
19
17
14
14
13
4

Werktuigbouwkunde

Motorvoertuigen en carrosserietechniek

Elektrotechniek

Technische informatica

Installatietechniek

Houtbewerking en woninginrichting

Grafische techniek

Proces- en laboratoriumtechniek

Administratie

Handel

Horeca

Toerisme en recreatie

Verpleging

Verzorging

$\begin{array}{llll}39 & 34 & 18 & 10\end{array}$

Assisterende beroepen in de gezondheidszor

Activiteitenbegeleiding

Civiele en consumptief technische diensten

Uiterlijke verzorging

Mode en kleding

Sociaal-juridische dienstverlening (AW/SA)

Sociaal-cultureel werker (AW/CW)

Zie ook toelichting bladzijde 35 
Tabel B3.13

Percentage werkende schoolverlaters dat op zoek is naar een andere baan

Opleidingsrichting

VBO

Landbouw en natuurlijke omgeving

Bouwtechniek

13

Consumptieve techniek

Handel

Verzorging

MBO-kort

Oriënteren en schakelen $\quad 38$

Plantenteelt (en handel) $\quad 19$

Veehouderij 15

Dierenverzorging en veterinaire ondersteuning 23

Groene ruimte $\quad 35$

Werktuigbouwkunde 16

Motorvoertuigen en carrosserietechniek $\quad 25$

$\begin{array}{ll}\text { Elektrotechniek } & 21\end{array}$

Administratie $\quad 37$

Handel

Horeca

Verzorging

Civiele en consumptief technische diensten

MBO-tussen en -lang

Plantenteelt (en handel)

Veehouderij

Levensmiddelentechnologie

Bloemschikken

Dierenverzorging en veterinaire ondersteuning 23

Groene ruimte 16

Bouwkunde

Werktuigbouwkunde

en carrosserietechniek

Elektrotechniek

Houtbewerking en woninginrichting

Weg-en waterbouwkunde $\quad 15$

Grafische techniek $\quad 24$

Proces- en laboratoriumtechniek $\quad 25$

Administratie $\quad 25$

\begin{tabular}{lr} 
Handel & 27 \\
\hline
\end{tabular}

$\begin{array}{ll}\text { Horeca } & 26\end{array}$

Toerisme en recreatie $\quad 23$

Verpleging 17

Verzorging

Assisterende beroepen in de gezondheidszorg

Activiteitenbegeleiding $\quad 26$

$\begin{array}{ll}\text { Civiele en consumptief technische diensten } & 27\end{array}$

$\begin{array}{ll}\text { Uiterlijke verzorging } & 41\end{array}$

Mode en kleding

Sociaal-juridische dienstverlening (AW/SA)

Sociaal-cultureel werker (AW/CW)

Sociaal-pedagogisch werker (AW/SW)

Zie ook toelichting bladzijde 36 
Tabel B3.14

Deelname aan een cursus of bedrijfsopleiding door werkende schoolverlaters

Opleidingsrichting

VBO

Landbouw en natuurlijke omgeving

Bouwtechniek

Consumptieve techniek

Handel

Verzorging

MBO-kort

$\begin{array}{ll}\text { Oriënteren en schakelen } & 15\end{array}$

Plantenteelt (en handel) 36

$\begin{array}{ll}\text { Veehouderij } & 10\end{array}$

$\begin{array}{lr}\text { Dierenverzorging en veterinaire ondersteuning } & 27 \\ \text { Groene ruimte } & 0\end{array}$

Werktuigbouwkunde

Motorvoertuigen en carrosserietechniek 31

27

Administratie 26

Handel 22

Horeca

Verzorging

Civiele en consumptief technische diensten

MBO-tussen en -lang

Plantenteelt (en handel)

Veehouderij

Levensmiddelentechnologie

Bloemschikken

Dierenverzorging en veterinaire ondersteuning 24

Groene ruimte

Bouwkunde

Werktuigbouwkunde

carrosserietechniek

Elektrotechniek

Technische informatica 44

Installatietechniek 26

Houtbewerking en woninginrichting 18

Weg- en waterbouwkunde $\quad 47$

Grafische techniek 14

Proces- en laboratoriumtechniek 22

Administratie 44

Handel 38

Horeca 36

Toerisme en recreatie 36

Verpleging 6

Verzorging 8

Assisterende beroepen in de gezondheidszorg $\quad 29$

Activiteitenbegeleiding 17

Civiele en consumptief technische diensten $\quad 23$

$\begin{array}{ll}\text { Uiterlijke verzorging } & 39 \\ \end{array}$

Sociaal-juridische dienstverlening (AW/SA) 38

$\begin{array}{lr}\text { Sociaal-cultureel werker (AW/CW) } & 14 \\ \text { Sociaal-pedagogisch werker (AW/SW) } & 14\end{array}$

Zie ook toelichting bladzijde 37 
Tabel B3.15

Belangrijkste cursussen of bedrijfsopleidingen waaraan werkende schoolverlaters deelnemen

$\%$

VBO Landbouw en natuurlijke omgeving

Techniek

Horeca

Landbouw

Veeteelt

Bouwkunde

Grafische techniek

Weg-, railvervoer

Secretarieel (incl. tekstverwerking, steno)

Bedrijfsadministratie, accountancy

Persoonlijke ontplooiing

17

17

8

8

8

VBO Consumptieve techniek

Computer en informatica 33

Horeca

VBO Handel

Techniek

Marketing, reclame

Verzekeringswezen

VBO Verzorging

Ziekenverzorging

MBO Kort Oriënteren en schakelen orienteren en schakelen

Administratief

Recht en openbare orde

Secretarieel (incl. tekstverwerking, steno)

Uiterlijke verzorging

MBO Kort Plantenteelt (en handel)

Bedrijfskunde, management, efficiency

Weg-, railvervoer

MBO Kort Veehouderij

Techniek

Weg-, railvervoer

MBO Kort Dierenverzorging en veterinaire ondersteuning

Landbouw
Secretarieel (incl. tekstverwerking, steno)
Veeteelt

MBO Kort Werktuigbouwkunde

Metaalbewerking

Bouwkunde

Elektrotechniek

MBO Kort Motorvoertuigen en carrosserietechniek

Techniek

Weg-, railvervoer 
Tabel B3.15 (vervolg)

Belangrijkste cursussen of bedrijfsopleidingen waaraan werkende schoolverlaters deelnemen

$\%$

\section{MBO Kort Elektrotechniek}

Elektrotechniek

Techniek

Telecommunicatie/datacommunicatie

Weg-, railvervoer

Landmacht

Grafische techniek

\section{MBO Kort Administratie}

Secretarieel (incl. tekstverwerking, steno)

Bedrijfsadministratie, accountancy

Administratief

Verzekeringswezen

Commercieel

Toerisme

Detailhandel (incl. middenstanddiploma)

Horeca

MBO Kort Handel

Detailhandel (incl. middenstanddiploma)

Techniek

Bedrijfskunde, management, efficiency

Commercieel

Marketing, reclame

Germaanse talen

\section{MBO Kort Horeca}

\section{Commercieel}

Recht en openbare orde

Administratief

Detailhandel (incl. middenstanddiploma)

Horeca

\section{MBO Kort Verzorging}

Commercieel

Verpleging

Horeca

Gezondheidszorg

MBO Kort Civiele en consumptief technische diensten

Administratief

Techniek

Bedrijfskunde, management, efficiency

Horeca

Zeemacht

21
7
2
0
7
7
7
5

MBO Plantenteelt (en handel)

Tuinbouw

Commercieel

Computer en informatica

Weg-, railvervoer

Landbouw 
Tabel B3.15 (vervolg)

Belangrijkste cursussen of bedrijfsopleidingen waaraan werkende schoolverlaters deelnemen

$\%$

MBO Veehouderij

Veeteelt

Landbouw

35

Bedrijfskunde, management, efficiency

Weg-, railvervoer

Algemene en bedrijfseconomie

MBO Levensmiddelentechnologie

Techniek

Ladingbehandeling

Administratief

Marketing, reclame

Horeca

Bedrijfskunde, management, efficiency

Romaanse talen

Farmacie

\section{MBO Bloemschikken}

Tuinbouw

Kunst en Cultuur

Geld- en bankzaken

Gezondheidszorg

MBO Dierenverzorging en veterinaire ondersteuning

Commercieel

Biologie

Veeteelt

Weg-, railvervoer

Bedrijfsadministratie, accountancy

Agrarische economie

Horeca

Gezondheidszorg

\section{MBO Groene ruimte}

Techniek

Weg-, railvervoer

Landbouw

Openbaar bestuur

Commercieel

Brandweer

\section{MBO Bouwkunde}

Bedrijfstechniek, technische bedrijfsvoering

Bouwkunde

Bedrijfskunde, management, efficiency

Computer en informatica

\section{MBO Werktuigbouwkunde}

Techniek

Elektrotechniek

Computer en informatica

Werktuigbouwkunde

Weg-, railvervoer 
Tabel B3.15 (vervolg)

Belangrijkste cursussen of bedrijfsopleidingen waaraan werkende schoolverlaters deelnemen

MBO Motorvoertuigen en carrosserietechniek

Elektrotechniek

Bouwkunde

Techniek

Commercieel

\section{MBO Elektrotechniek}

Computer en informatica

Elektrotechniek

Techniek

Telecommunicatie/datacommunicatie

Elektronica oriënteren en schakelen/radio-TV

MBO Technische informatica

Computer en informatica

Industriele procesautomatisering

Germaanse talen

MBO Installatietechniek

Elektrotechniek

Techniek

Computer en informatica

MBO Houtbewerking en woninginrichting

Computer en informatica

Techniek

Commercieel

Bouwkunde

Bedrijfstechniek, technische bedrijfsvoering

Bedrijfsadministratie, accountancy

Communicatieve vaardigheden

Romaanse talen

Natuurkunde, materiaalkunde

\section{MBO Weg- en waterbouwkunde}

Bedrijfstechniek, technische bedrijfsvoering

Computer en informatica

Weg-en waterbouwkunde, landmeetkunde

Bedrijfskunde, management, efficiency

Werktuigbouwkunde

Commercieel

Detailhandel (incl. middenstanddiploma)

Gezondheidszorg

MBO Grafische techniek

Computer en informatica

Grafische techniek

Bedrijfskunde, management, efficiency

Commercieel

Marketing, reclame

MBO Proces- en laboratoriumtechniek

Techniek

Gezondheidszorg

Laboratoriumpersonee

Bedrijfskunde, management, efficiency 
Tabel B3.15 (vervolg)

Belangrijkste cursussen of bedrijfsopleidingen waaraan werkende schoolverlaters deelnemen

$\%$

\section{MBO Administratie}

Bedrijfsadministratie, accountancy

Verzekeringswezen

Computer en informatica

Marketing, reclame

Commercieel

Administratie

Secretarieel (incl. tekstverwerking, steno)

Bedrijfskunde, management, efficiency

\section{MBO Handel}

Marketing, reclame

Bedrijfskunde, management, efficiency

Commerciee

Bedrijfsadministratie, accountancy

Computer en informatica

Verzekeringswezen

Weg-, railvervoer

\section{MBO Horeca}

Bedrijfskunde, management, efficiency

Toerisme

Commercieel

Marketing, reclame

Germaanse talen

Techniek

Communicatieve vaardigheden

Bedrijfsadministratie, accountancy

Romaanse talen

MBO Toerisme en recreatie

Toerisme

Romaanse talen

Computer en informatica

Commercieel

Secretarieel (incl. tekstverwerking, steno)

Germaanse talen

Marketing, reclame

\section{MBO Verpleging}

Verpleging

Computer en informatica

Commercieel

Medisch secretariee

Fysiotherapie, bewegingsleer

\section{MBO Verzorging}

Verpleging

Medisch secretarieel

Commercieel

Techniek

Kinderverzorging

Sociale wetenschappen 
Tabel B3.15 (vervolg)

Belangrijkste cursussen of bedrijfsopleidingen waaraan werkende schoolverlaters deelnemen

$\%$

MBO Assisterende beroepen en de gezondheidszorg

Farmacie

Gezondheidszorg

Verpleging

Commercieel

Medisch secretarieel

MBO Activiteitenbegeleiding

$\begin{array}{lr}\text { Verpleging } & 24 \\ \text { Bejaardenverzorging } & 16 \\ \text { Sociale wetenschappen } & 13 \\ \text { Detailhandel (incl. middenstanddiploma) } & 9 \\ \text { Maatschappelijk werk } & 9 \\ \text { Economie } & 7 \\ \text { Sociale vorming } & 7 \\ \text { Persoonlijke ontplooiing } & 7 \\ \text { Farmacie } & 7\end{array}$

MBO Civele en consumptief technische diensten

Horeca

Weg-, railvervoer

Bedrijfstechniek, technische bedrijfsvoering

Diëtetiek

Detailhandel (incl. middenstanddiploma)

Bedrijfskunde, management, efficiency

Tandheelkunde

BO Uiterlijke verzorging

Uiterlijke verzorging

Commercieel

Detailhandel (incl. middenstanddiploma)

Secretarieel (incl. tekstverwerking, steno)

MBO Mode en Kleding

Secretarieel (incl. tekstverwerking, steno)

Techniek

Computer en informatica

Grafische techniek

Uiterlijke verzorging

Bedrijfskunde, management, efficiency

Marketing, reclame

MBO Sociaal-juridische dienstverlening (AWISA)

Computer en informatica

Maatschappelijk werk

Personeelswerk

Geld-en bankzaken

Secretarieel (incl. tekstverwerking, steno)

Horeca

Sociaal werk

Germaanse talen

Verzekeringswezen

Detailhandel (incl. middenstanddiploma) 
Tabel B3.15 (vervolg)

Belangrijkste cursussen of bedrijfsopleidingen waaraan werkende schoolverlaters deelnemen

$\%$

MBO Sociaal-cultureel werker (AW/CW)

Maatschappelijk werk 50

Basisonderwijs/onderwijzers (incl. remedial teacher)

25

Communicatieve vaardigheden

MBO Sociaal-pedagogisch werker (AWISW)

\author{
Verpleging \\ Secretarieel (incl. tekstverwerking, steno) \\ Maatschappelijk werk \\ Computer en informatica \\ Sociale wetenschappen \\ Gedrag en Maatschappij \\ Communicatieve vaardigheden \\ Detailhandel (incl. middenstanddiploma) \\ Persoonlijke ontplooiing
}

De in deze tabel gepresenteerde percentages zijn soms gebaseerd op zeer kleine aantallen. 


\section{Respons}


$\infty$ 
Tabel C. 1

Ongewogen aantal respondenten verbijzonderd naar bestemming per opleidingssector

\begin{tabular}{llr}
\hline Opleidingssector studie & $\begin{array}{l}\text { LLW/ } \\
\text { in-serv }\end{array}$ & $\begin{array}{r}\text { betald werkloos anders onbekend totaal } \\
\text { werk }\end{array}$ \\
\hline
\end{tabular}

AVO

MAVO

HAVO

WO

$635 \quad 56$

$\begin{array}{rr}56 & 82 \\ 44 & 164 \\ 11 & 68\end{array}$

8
15
7
30

$\begin{array}{rrr}14 & 103 & 898 \\ 18 & 54 & 1.188 \\ 9 & 20 & 1.049 \\ 41 & 177 & 3.135\end{array}$

VBO

landbouw

techniek

economie

934
2.462

111

68
314

30

1.049

3.135

gezondheidszorg

$\begin{array}{rrr}246 & 43 & 66 \\ 97 & 52 & 59 \\ 95 & 7 & 50 \\ 99 & 19 & 41 \\ 537 & 121 & 216\end{array}$

4
15
14
5
38

$\begin{array}{rrr}7 & 44 & 410 \\ 9 & 44 & 276 \\ 6 & 24 & 196 \\ 7 & 37 & 208 \\ 29 & 149 & 1.090\end{array}$

\section{MBO-kort}

$\begin{array}{lrr}\text { oriënteren en schakelen } & 71 & 11 \\ \text { landbouw } & 16 & \\ \text { techniek } & 35 & 32 \\ \text { economie } & 105 & 45 \\ \text { gezondheidszorg } & 50 & 31 \\ \text { Totaal } & 277 & 132 \\ & \end{array}$

\section{MBO-tussen en -lang}

\begin{tabular}{|c|c|c|c|c|c|c|c|}
\hline $\begin{array}{l}\text { landbouw } \\
\text { techniek } \\
\text { economie } \\
\text { gezondheidszorg } \\
\text { gedrag en maatschappij } \\
\text { Totaal }\end{array}$ & $\begin{array}{r}199 \\
585 \\
628 \\
314 \\
253 \\
1.979\end{array}$ & $\begin{array}{r}22 \\
37 \\
27 \\
152 \\
53 \\
291\end{array}$ & $\begin{array}{r}571 \\
1.011 \\
1.386 \\
1.060 \\
389 \\
4.417\end{array}$ & $\begin{array}{r}40 \\
37 \\
90 \\
70 \\
39 \\
276\end{array}$ & $\begin{array}{r}15 \\
26 \\
27 \\
18 \\
6 \\
92\end{array}$ & $\begin{array}{r}42 \\
65 \\
83 \\
97 \\
51 \\
338\end{array}$ & $\begin{array}{r}889 \\
1.761 \\
2.241 \\
1.711 \\
791 \\
7.393\end{array}$ \\
\hline \multicolumn{8}{|l|}{ HBO } \\
\hline $\begin{array}{l}\text { landbouw } \\
\text { onderwijs } \\
\text { techniek } \\
\text { economie } \\
\text { gezondheidszorg } \\
\text { gedrag en maatschappij } \\
\text { kunst en cultuur } \\
\text { Totaal }\end{array}$ & $\begin{array}{r}122 \\
139 \\
367 \\
621 \\
89 \\
151 \\
144 \\
1.633\end{array}$ & $\begin{array}{l}x \\
x \\
x \\
x \\
x \\
x \\
x \\
x\end{array}$ & $\begin{array}{r}755 \\
999 \\
2.466 \\
3.505 \\
860 \\
1.102 \\
993 \\
10.680\end{array}$ & $\begin{array}{r}75 \\
77 \\
142 \\
145 \\
46 \\
111 \\
136 \\
732\end{array}$ & $\begin{array}{r}19 \\
19 \\
28 \\
31 \\
9 \\
34 \\
78 \\
218\end{array}$ & $\begin{array}{r}5 \\
11 \\
18 \\
22 \\
5 \\
11 \\
10 \\
82\end{array}$ & $\begin{array}{r}976 \\
1.245 \\
3.021 \\
4.324 \\
1.009 \\
1.409 \\
1.361 \\
13.345\end{array}$ \\
\hline Totaal & 6.888 & 655 & 16.163 & 1.150 & 416 & 886 & 26.158 \\
\hline
\end{tabular}

$\mathrm{x}=$ antwoordcategorie niet opgenomen

Toelichting

De aantallen in deze tabel betreffen het feitelijke aantal respondenten waarvan de gegevens in de analyses zijn opgenomen. 
Tabel C.2

Naar landelijke populatie gewogen aantal schoolverlaters verbijzonderd naar bestemming per opleidingssector

\begin{tabular}{llrl}
\hline Opleidingssector studie & $\begin{array}{l}\text { LLW/ } \\
\text { in-serv }\end{array}$ & $\begin{array}{r}\text { betaald werkloos anders onbekend totaal } \\
\text { werk }\end{array}$ & werk \\
\hline
\end{tabular}

AVO

MAVO

HAVO

37.100

3.300

4.600

400

$800 \quad 6.000$

52.200

WWO

27.500

1.100

3.900

300

300
4.600

10.200

1.000

400

1.700

34.900

Totaal

93.100

1.000

8.100

31.400

VBO

landbouw

techniek

2.500

400

700

40

70

400

118.500

economie

8.800

4.500

5.800

2.300

1.300

800

3.900

1.200

$\begin{array}{rr}400 & 1.900 \\ 1.600 & 7.500\end{array}$

4.200

25.000

$\begin{array}{lr}1.000 & 2.100 \\ 6.400 & 10.800\end{array}$

200

10.100

11.100

21.600

10.800

2.400

50.300

\section{MBO-kort}

oriënteren en schakelen 3.800

techniek

economie

40
700
2.300
600
7.500

600

1.600

300

2.800

4.400

800

400

2.500

10.000

500

60
300

1.600

$\begin{array}{rr}200 & 1.700 \\ 0 & 100 \\ 200 & 500\end{array}$

$300 \quad 800$

$100 \quad 300$

3.300

8.400

500

5.200

9.300

2.400

25.800

\section{MBO-tussen en -lang}

$\begin{array}{lrrrrrrr}\text { landbouw } & 900 & 100 & 2.600 & 200 & 100 & 200 & 4.000 \\ \text { techniek } & 8.000 & 700 & 12.400 & 600 & 300 & 800 & 22.800 \\ \text { economie } & 7.600 & 300 & 15.000 & 1.000 & 300 & 900 & 25.100 \\ \text { gezondheidszorg } & 1.700 & 900 & 5.900 & 400 & 100 & 600 & 9.600 \\ \text { gedrag en maatschappij } & 1.900 & 400 & 2.700 & 300 & 50 & 400 & 5.800 \\ \text { Totaal } & 20.000 & 2.300 & 38.600 & 2.500 & 900 & 2.900 & 67.300\end{array}$

HBO

\begin{tabular}{|c|c|c|c|c|c|c|c|}
\hline $\begin{array}{l}\text { landbouw } \\
\text { onderwijs } \\
\text { techniek } \\
\text { economie } \\
\text { gezondheidszorg } \\
\text { gedrag en maatschapp } \\
\text { kunst en cultuur } \\
\text { Totaal }\end{array}$ & $\begin{array}{r}500 \\
700 \\
1.200 \\
1.500 \\
300 \\
400 \\
400 \\
5.100\end{array}$ & $\begin{array}{l}x \\
x \\
x \\
x \\
x \\
x \\
x \\
x\end{array}$ & $\begin{array}{r}3.300 \\
4.700 \\
8.300 \\
8.400 \\
2.700 \\
3.200 \\
2.400 \\
33.000\end{array}$ & $\begin{array}{r}300 \\
400 \\
500 \\
300 \\
100 \\
300 \\
300 \\
2.300\end{array}$ & $\begin{array}{r}80 \\
100 \\
100 \\
70 \\
20 \\
90 \\
200 \\
600\end{array}$ & $\begin{array}{r}20 \\
50 \\
60 \\
50 \\
20 \\
30 \\
40 \\
300\end{array}$ & $\begin{array}{r}4.200 \\
5.900 \\
10.200 \\
10.400 \\
3.200 \\
4.000 \\
3.400 \\
41.300\end{array}$ \\
\hline Totaal & 147.300 & 15.800 & 102.619 & 9.764 & 5.564 & 22.068 & 303.102 \\
\hline
\end{tabular}

$\mathrm{x}=$ antwoordcategorie niet opgenomen

Toelichting

De aantallen in deze tabel zijn zodanig opgehoogd dat een representatief beeld wordt gegeven van de totale populatie van schoolverlaters. 
Tabel C.3

Responspercentage per opleidingssector

Opleidingssector

$\%$

AVo

MAVO

HAVO

WWO

Totaal

59

70

69

VBO

landbouw

techniek

economie

52

gezondheidszorg

59

gezondheidszorg

49

MBO-kort

oriënteren en schakelen

landbouw

techniek

economie

gezondheidszorg

Totaal

MBO-tussen en -lang

landbouw

techniek

economie

gezondheidszorg

gedrag en maatschappij

Totaal

53

50

55

59

53

HBO

landbouw

onderwijs

techniek

economie

54

gedrag en maatschappij

kunst en cultuur

Totaal

Totaal 54

Toelichting

De responspercentages geven een beeld van het aandeel van de uitgezette vragenlijsten dat bruikbaar retour is gekomen. Bij de in de tabel gepresenteerde percentages zijn bij het AVO en het VBO de in de gemeente Amsterdam uitgezette en ontvangen vragenlijsten buiten beschouwing gelaten, omdat hier - door een afwijkende vorm van adresvergaring - geen goed beeld van de feitelijke aangeschreven populatie voorhanden is. Overigens wordt opgemerkt dat de respons onder die groep wel beduidend lager ligt. 


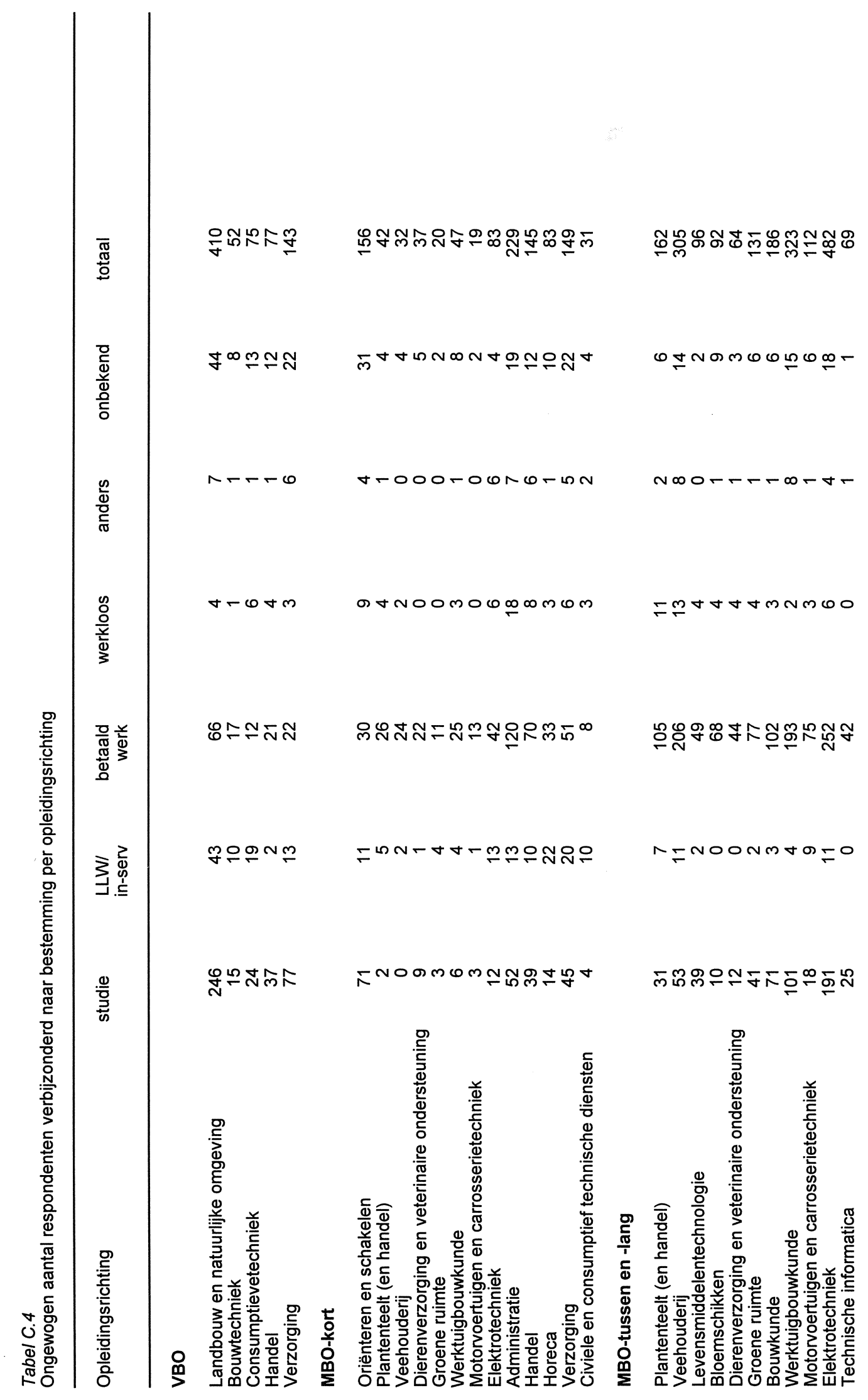




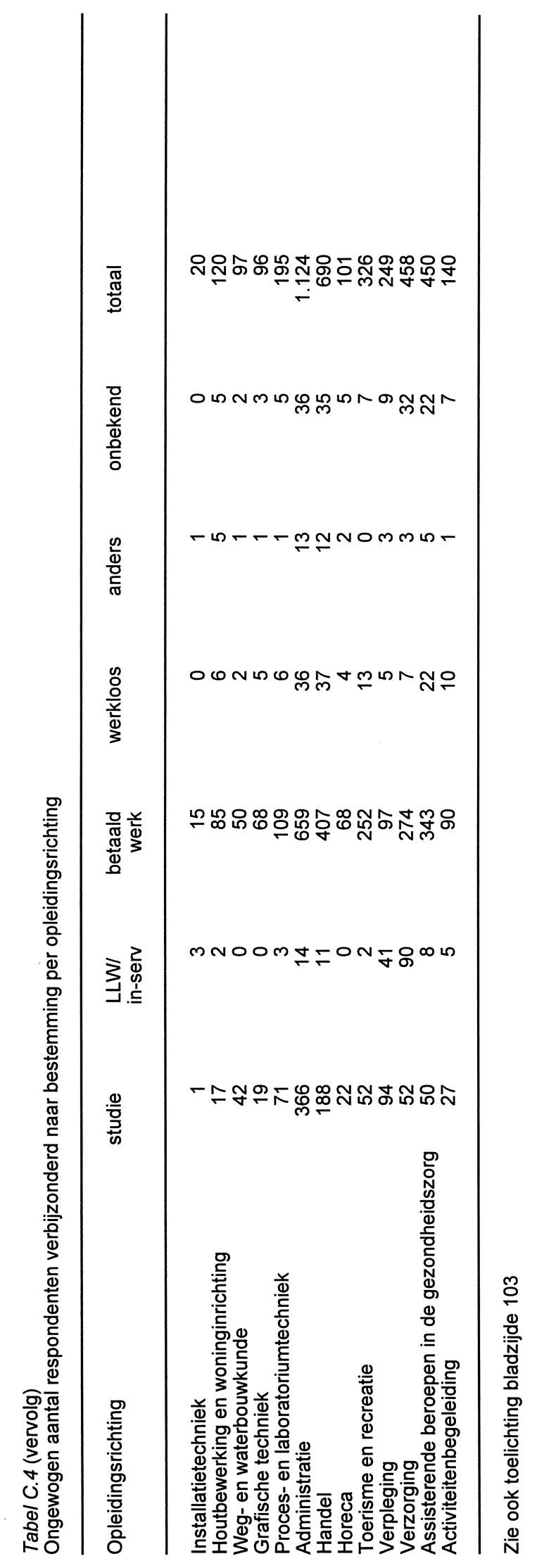




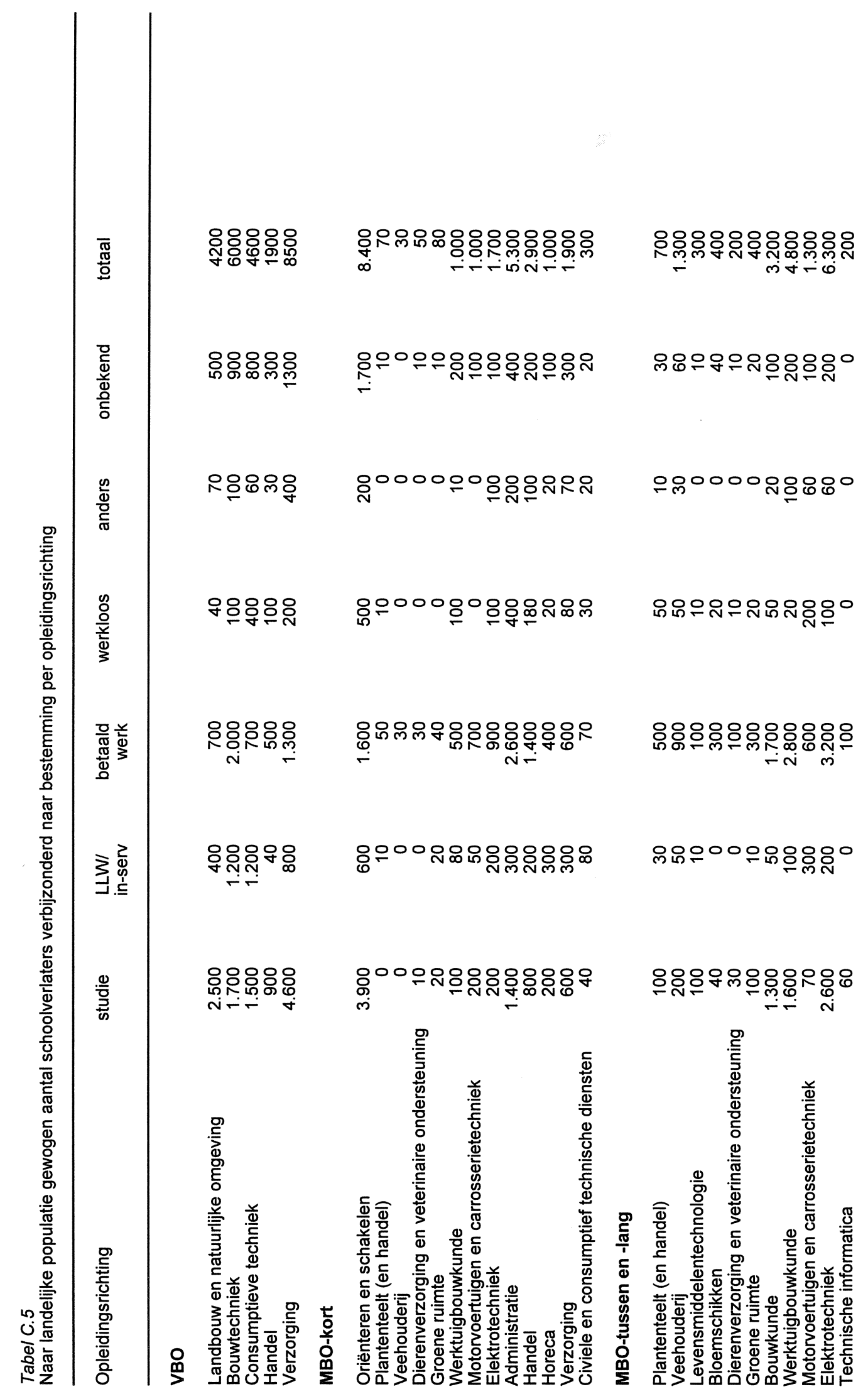




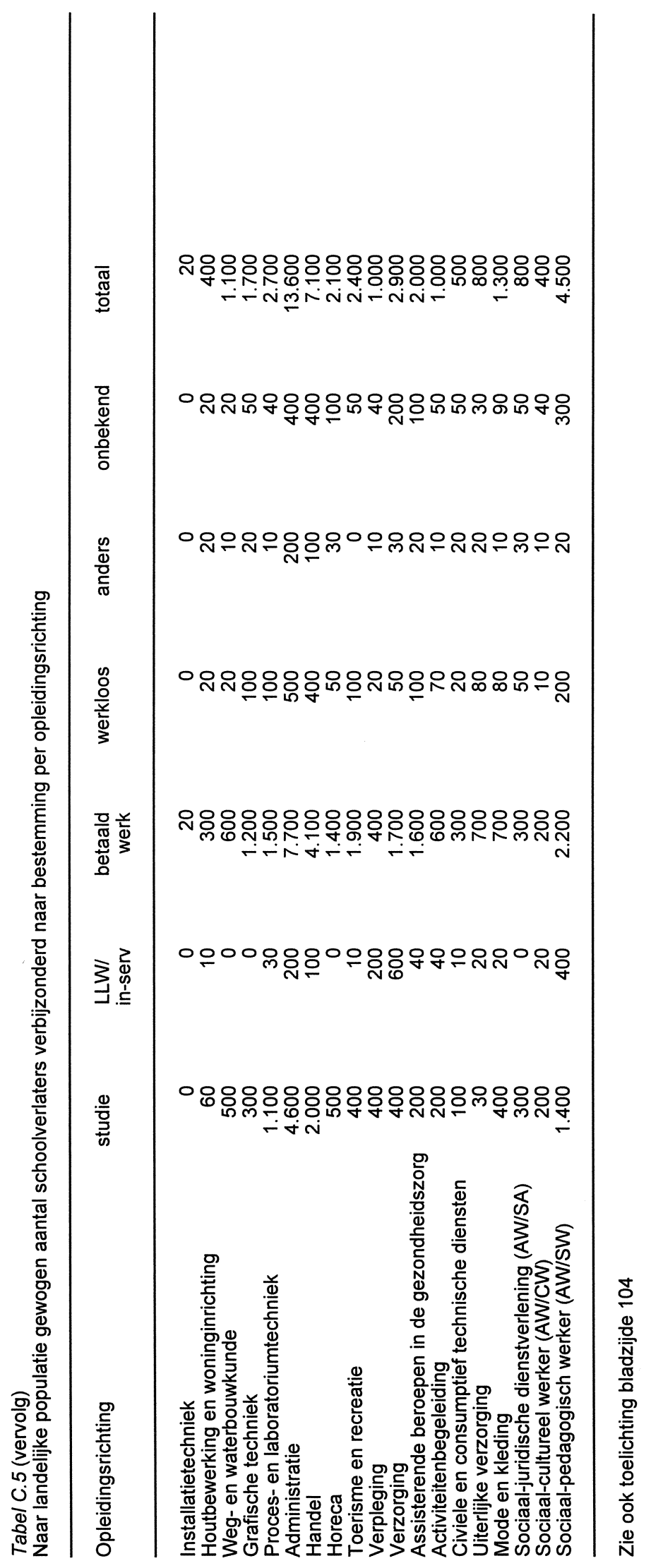


Tabel C.6

Responspercentage per opleidingsrichting

Opleidingsrichting

VBO

Landbouw en natuurlijke omgeving

Bouwtechniek

41

Consumptieve techniek

68

Hande

Verzorging

MBO-kort

Oriënteren en schakelen Orienteren en schakelen

Plantenteelt (en handel)

Veehouderij

geterinaire ondersteuning

Groene ruimte

Werktuigbouwkunde

$\begin{array}{ll}\text { Motorvoertuigen en carrosserietechniek } & 29\end{array}$

Elektrotechniek $\quad 36$

Administratie $\quad 41$

$\begin{array}{lr}\text { Handel } & 37\end{array}$

$\begin{array}{ll}\text { Horeca } & 41\end{array}$

Verzorging 46

Civiele en consumptief technische diensten $\quad 48$

MBO-tussen en -lang

Plantenteelt (en handel)

Veehouderij

49

Levensmiddelentechnologie

55

Bloemschikken $\quad 50$

Dierenverzorging en veterinaire ondersteuning $\quad 65$

Groene ruimte $\quad 57$

Bouwkunde

Werktuigbouwkunde

carrosserietechniek

Elektrotechniek

Technische informatica

Installatietechniek

woninginrichting

Weg- en waterbouwkunde $\quad 58$

Grafische techniek $\quad 42$

Proces- en laboratoriumtechniek

Administratie $\quad 59$

$\begin{array}{ll}\text { Handel } & 51\end{array}$

$\begin{array}{ll}\text { Horeca } & 34\end{array}$

Toerisme en recreatie $\quad 60$

$\begin{array}{lc}\text { Verpleging } & 64\end{array}$

$\begin{array}{ll}\text { Verzorging } & 64\end{array}$

Assisterende beroepen in de gezondheidszorg $\quad 65$

Activiteitenbegeleiding $\quad 58$

Civiele en consumptief technische diensten $\quad 58$

Uiterlijke verzorging $\quad 53$

46

Sociaal-juridische dienstverlening (AW/SA)

Sociaal-cultureel werker (AW/CW)

Sociaal-pedagogisch werker (AW/SW)

Zie ook toelichting bladzijde 105 
D. Opleidingsindeling 


\title{
Overzicht van opleidingen per opleidingssector
}

\author{
MAVO \\ MAVO \\ HAVO \\ HAVO \\ HAVO-MBO \\ VHBO \\ VWO \\ WWO \\ VBO Landbouw \\ VBO Landbouw en natuurlijke omgeving \\ VBO Techniek \\ VBO Bouwtechniek \\ VBO Mechanische techniek \\ VBO Elektrotechniek \\ VBO Installatietechniek \\ VBO Motorvoertuigentechniek \\ VBO Consumptieve techniek \\ VBO Grafische techniek \\ VBO Nautische opleidingen \\ VBO Economie \\ VBO Administratie \\ VBO Verkoop \\ VBO Handel \\ VBO Gezondheidszorg \\ VBO Verzorging \\ VBO Uiterlijke verzorging \\ VBO Mode en kleding \\ MBO Kort Algemeen \\ MBO Kort Oriënteren en schakelen \\ MBO Kort Landbouw \\ MBO Kort Plantenteelt (en handel) \\ MBO Kort Veehouderij \\ MBO Kort Levensmiddelentechnologie \\ MBO Kort Bloemschikken \\ MBO Kort Dierenverzorging en veterinaire ondersteuning \\ MBO Kort Biologisch-dynamische land- en tuinbouw \\ MBO Kort Groene ruimte \\ MBO Kort Techniek \\ MBO Kort Bouwkunde \\ MBO Kort Werktuigbouwkunde \\ MBO Kort Motorvoertuigen en carrosserietechniek \\ MBO Kort Elektrotechniek \\ MBO Kort Installatietechniek \\ MBO Kort Houtbewerking en woninginrichting
}


MBO Kort Grafische techniek

MBO Kort Mode en kleding

MBO Kort Proces- en laboratoriumtechniek

MBO Kort Brood- en banketbakken

MBO Kort Economie

MBO Kort Administratie

MBO Kort Handel

MBO Kort Horeca

MBO Kort Basiskok

MBO Kort Gezondheidszorg

MBO Kort Verzorging

MBO Kort Civiele en consumptief technische diensten

MBO Kort Uiterlijke verzorging

MBO Kort Haarverzorging

MBO Landbouw

MBO Tussen Plantenteelt (en handel)

MBO Tussen Veehouderij

MBO Tussen Levensmiddelentechnologie

MBO Tussen Bloemschikken

MBO Tussen Dierenverzorging en veterinaire ondersteuning

MBO Tussen Groene ruimte

MBO Plantenteelt (en handel)

MBO Veehouderij

MBO Levensmiddelentechnologie

MBO Bloemschikken

MBO Dierenverzorging en veterinaire ondersteuning

MBO Biologisch-dynamische land- en tuinbouw

MBO Groene ruimte

MBO Techniek

MBO Tussen Werktuigbouwkunde

MBO Tussen Elektrotechniek

MBO Tussen Proces- en laboratoriumtechniek

MBO Bouwkunde

MBO Werktuigbouwkunde

MBO Motorvoertuigen en carrosserietechniek

MBO Elektrotechniek

MBO Technische informatica

MBO Installatietechniek

MBO Fotonica

MBO Fijnmechanische techniek

MBO Houtbewerking en woninginrichting

MBO Weg- en waterbouwkunde

MBO Grafische techniek

MBO Proces- en laboratoriumtechniek

MBO Nautische opleidingen

MBO Algemene operationele techniek

MBO Economie

MBO Administratie

MBO Handel

MBO Horeca

MBO Toerisme en recreatie 
MBO Gezondheidszorg

MBO Verpleging

MBO Verzorging

MBO Assisterende beroepen in de gezondheidszorg

MBO Activiteitenbegeleiding

MBO Civiele en consumptief technische diensten

MBO Uiterlijke verzorging

MBO Mode en kleding

MBO Gedrag en maatschappij

MBO Sociaal-juridische dienstverlening (AW/SA)

MBO Sociaal-cultureel werker (AW/CW)

MBO Sociaal-pedagogisch werker (AW/SW)

HBO Landbouw

HBO Tropische landbouw

HBO Tuinbouw

HBO Plantenteelt

HBO Veehouderij

HBO Landbouw \& veehouderij

HBO Agrarische bedrijfskunde

HBO Internationale agrarische handel

HBO Agrologistiek

HBO Milieukunde

HBO Tuin- en landschapsinrichting

HBO Bos- en natuurbeheer

HBO Land, water en milieubeheer

HBO Laboratoriumtechniek

HBO Levensmiddelentechnologie

HBO Agroproduktkunde

HBO Docent plantenteelt en verwerking

HBO Docent veehouderij en verwerking

HBO Docent levensmiddelentechnologie

HBO Docent agrarische economie

HBO Docent agrarische techniek

HBO Onderwijs

HBO Leraar basis-/speciaalonderwijs

HBO Leraar VO taal 1-vak (2e gr.)

HBO Leraar VO maatschappij 1-vak (2e gr.)

HBO Leraar VO exact 1-vak (2e gr.)

HBO Leraar VO expressie 1-vak (2e gr.)

HBO Leraar VO taal (1e gr.)

HBO Leraar VO maatschappij (1e gr.)

HBO Leraar VO exact (1e gr.)

HBO Leraar VO taal combinaties (2e gr.)

HBO Leraar VO maatschappij combinaties (2e gr.)

HBO Leraar VO exact combinaties (2e gr.)

HBO Leraar VO expressie combinaties (2e gr.)

HBO Leraar VO taal \& maatschappij combinaties (2e gr.)

HBO Leraar VO exact \& maatschappij combinaties (2e gr.)

HBO Leraar VO 2 vakken combinaties (2e gr.)

HBO Techniek

HBO Kort Techniek

HBO Bouwkunde 
HBO Civiele techniek

HBO Geodesie

HBO Verkeerskunde

HBO Ruimtelijke ordening en planologie

HBO Milieukunde

HBO Logistiek en technische vervoerskunde

HBO Elektrotechniek

HBO Computertechniek

HBO Hogere informatica

HBO Informatica en informatiekunde

HBO Werktuigbouwkunde

HBO Autotechniek

HBO Scheepsbouwkunde

HBO Technische natuurkunde

HBO Industrieel produkt ontwerpen

HBO Chemische technologie

HBO Aquatische ecotechnologie

HBO Technische bedrijfskunde

HBO AOT-techniek

HBO Maritiem officier

HBO Analytische proces- en laboratoriuminstrumentatie

HBO Biologische laboratoriumopleiding

HBO Chemische laboratoriumopleiding

HBO Medische laboratoriumopleiding

HBO Laboratoriuminformatica en automatisering

HBO Economie

HBO Kort Toeristisch en recreatief onderwijs

HBO Accountancy

HBO Bedrijfseconomie (ook OU)

HBO Fiscale economie

HBO Hoger onderwijs financiële sector (HBO-variant)

HBO Bedrijfskundige informatica

HBO Bestuurskunde/overheidsmanagement

HBO Opleiding voor management, economie en recht

HBO Commerciële economie

HBO Logistiek en economie

HBO Economisch-linguistische opleiding

$\mathrm{HBO}$ Voeding en marketing

HBO Bibliotheek en documentaire informatie

HBO Communicatie

HBO Communicatiesystemen

HBO Journalistiek en voorlichting

HBO Opleiding tolk-vertaler

HBO Facilitaire dienstverlening

HBO Hoger hotelonderwijs

HBO Hoger toeristisch en recreatief onderwijs

HBO Vrijetijdskunde

HBO Gezondheidszorg

HBO Opleiding tot verpleegkundige

HBO Opleiding tot verpleegkundige in de maatschappelijke gezondheidszorg (MGZ)

HBO Opleiding van kader in de gezondheidszorg

HBO Bewegingstechnologie

HBO Medisch beeldvormende en radiotherapeutische technieken

HBO Opleiding tot fysiotherapeut 
HBO Opleiding voor logopedie

HBO Voeding en diëtetiek

HBO Mondhygiënist

HBO Orthoptie

HBO Huidtherapie

HBO Oefentherapie Cesar

HBO Podotherapie

HBO Lerarenopleiding verpleegkunde (2e gr.)

HBO Gedrag en maatschappij

HBO Creatieve therapie

HBO Culturele en maatschappelijke vorming

HBO Expressie door woord en gebaar

HBO Maatschappelijk werk en dienstverlening

HBO Personeel en arbeid

HBO Sociaal-juridische dienstverlening

HBO Sociaal-pedagogische hulpverlening

HBO Kunst en cultuur

HBO Algemene industriële vormgeving

HBO Architectonische vormgeving

HBO Film- en t.v.-vormgeving

HBO Fotografische vormgeving

HBO Keramische vormgeving

HBO Modevormgeving

HBO Monumentale vormgeving

HBO Museologie

HBO Plastische vormgeving

HBO Publiciteits- c.q. grafische vormgeving

HBO Schilderkundige vormgeving en vormgeving op het gebied van de grafiek

HBO Textiele vormgeving

HBO Vormgeving in metalen en kunststoffen

HBO Beeldende Kunst en Vormgeving - vrij

HBO Compositie of compositie/elektronische muziek

HBO Directie koor, orkest of harmonie en fanfare

HBO Docerend musicus

HBO Muziekdramatische opleiding

HBO Muziekregistratie

HBO Theorie der muziek

HBO Uitvoerend musicus

HBO Muziek - 1e fase

HBO Muziek - vrije richting

HBO Opleiding praktijkdiploma beiaard

HBO Opleiding praktijkdiploma directie harmonie en fanfare

HBO Opleiding praktijkdiploma kerkmuziek

HBO Opleiding praktijkdiploma koordirectie

HBO Opleiding praktijkdiploma orgel

HBO Opleiding praktijkdiploma orkest- en ensembleleiding

HBO Uitvoerende beoefening van de mime

$\mathrm{HBO}$ cultuur Uitvoerende beoefening van het drama

HBO Uitvoerende beoefening van de dans

HBO Opleiding leraar handvaardigheid (1e gr.)

HBO Opleiding leraar textiele werkvormen (1e gr.)

HBO Opleiding leraar tekenen (1e gr.)

HBO Staatsdiploma handvaardigheid B

HBO Getuigschrift muziekonderwijs A algemene muzikale vorming 
HBO Getuigschrift muziekonderwijs B schoolmuziek HBO Opleiding docentschap dans

HBO Opleiding docentschap drama

HBO Opleiding docentschap mime

HBO Kunst en techniek

HBO Kunst/mediamanagement 